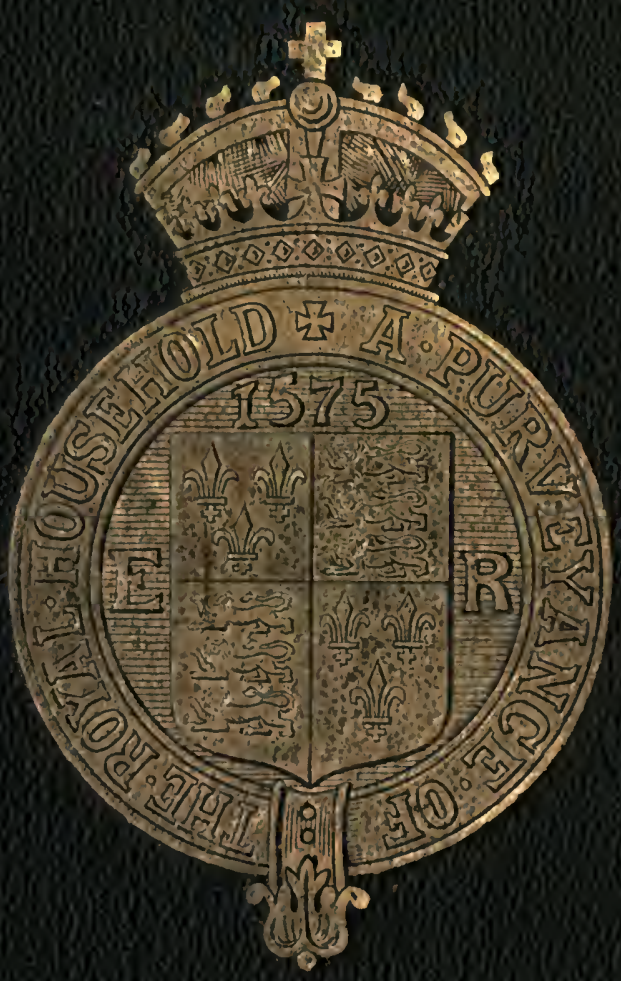







\section{A Purveyance}

of the Royal bousebold

in the Elizabet5an Age. 

Digitized by the Internet Archive in 2007 with funding from Microsoft Corporation 


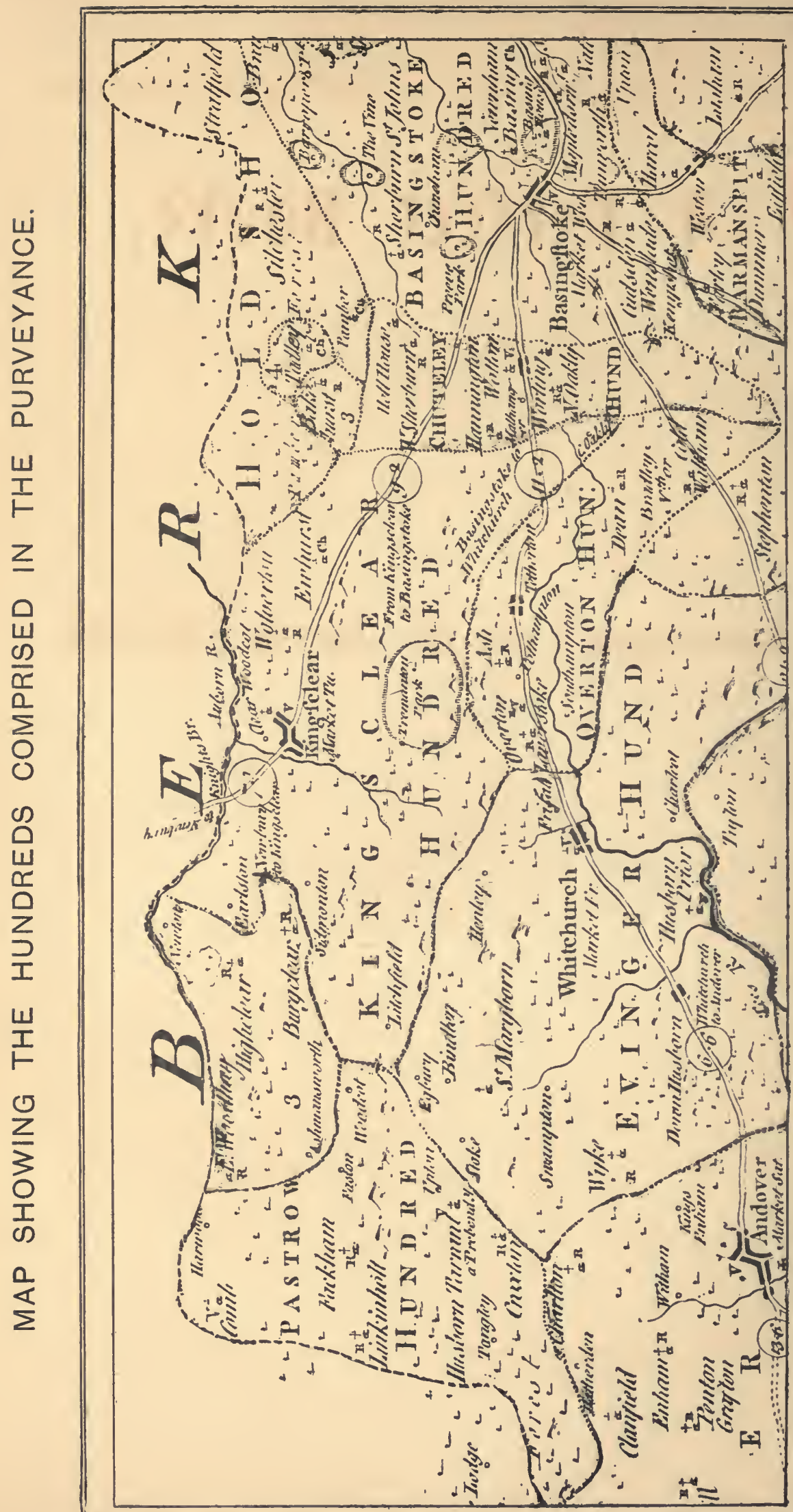




\section{A Periect Booke,}

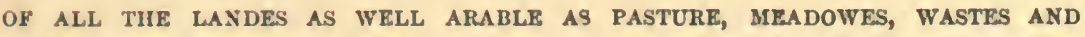
WASTE GROUNDES, WTTH THE GOODNESS OF THE SAME, AS WELL AS IN WHOSE ILANDES AND OCCUPACION THE SAME IS

WITHIN THE HUNDREDS OF EVENGER, CHUTLYE, KINGSCLERE, PASTROE, AND OVERTON,

VEWED, SEENE, AND NUMBERED BY ESTLMACION IN THE YEAR OF OUR LORD

$$
1575 \text {, }
$$

BY CERTEINE INNHABITANTS THERE AT THE COMMANDEMENT OF THE JUSTICES OP THE PEACE OF OUR

\section{Soveraigne cady the Queene Elizabeth,}

WITHIN HER GRACES COUNTY OF SOUTHAMPTON,

AND FURTHERMORE

HOW MUTCH AND UPON WHOME THE WHOLE SUMME AND RATE OF WHEATE, StUrtes, Lambes, and Poultrye thereby MAY best BE LeVied for Provision of The QueENe's Majesties most hoNourable Householde at SUTCH TIME AS THE SAME SHALBE REQUESTED.

NOW FIRST PUBLISHED

From the original MS. in the Wood Library, Whitchurch, IN THE COUNTY OF SOUTHAMPTON,

WITH INTRODUCTION AND NOTES, BY

WALTER MONEY, F.S.A.,

Local Secretary for Berks, Society of Antiquaries of London, and of the British Archaological Association.

A uthor of The History of Newbury, The Battles of Newbury, The History of

- Hungerford, The History of Speen, Church Goods in Berkshire,

The Siege of Basing House, a transcript with notes, Lot Meads de Commonable Lands. and other Works.

\section{NEWBURY :}

PRINTED AND PUBLISHED BY W. J. BLACKET, NORTHBROOK STREKT.

$$
\text { unccedr. }
$$




$$
\begin{aligned}
& \text { HJ } \\
& 2287 \\
& \text { G7M } 6
\end{aligned}
$$




\section{IIST OF SUBSCRIBERS.}

Sir Alexander J. Arbuthnot, K.C.S.I., C.I.E., Newtown Honse, Newbury,

Francis Bacon, Esq., Earlstone, Newbury.

Mrs. Ball, Riverside, Donnington, Newbury

Mrs. Batson, Welford Rectory, Newbury,

The Rt. Hon. W. W. B. Beach, M.P., Oakley Manor, Basingstoke.

W. Heward Bell, Esq., Cleeve Hoase, Melksham, Wilts.

The Rev. R. F. Bigg-Wither, Wonston Rectory, Micheldever.

E. B. Black-Hawkins, Esq., The Upper Link, St. Mary Bonrne, (2 copies).

W. F. Blandy, Esq., 1, Friar Street, Reading.

The Rev. Canon Blunt, Raral Dean, Burghclere Rectory, Newbary.

Alfred Bowker, Esq., J.P., Mayor of Winchester.

James Buchanan, Esq., 5, Stanhope Street, Hyde Park, (12 copies).

The Rt. Hon. Lord Burghclere, 48 Charles Street, Berkeley-square, London.

Lt.-Col. Sir Frederick W. Carden, Bart., Stargrove, Newbury.

The Rt. Hon, the Earl of Carnarvon, Highclere Castle, Newbury.

The Rev. E. B. C. Charchill, Ashmansworth, Newbary.

Mrs. Cole, West Woodhay House, Newbury.

John Hauteville Cope, Esq., F.R. Hist. Soc., Sulhamstead Park, Reading.

John Copland, Esg., Sheerness.

Mr. G. J. Cosburn, Newbury.

Frederick Cowslade, Esq., Erleigh, Reading.

Ernest Crofts, Esq., R.A., Barlington, House, Piccadilly.

Frederick Crowley, Esq., Ashdell, Alton.

C. R. De la Salle, Esq., Enbridge, Newbary.

The Rev. P. H. Ditchfield, M.A., F.S.A., Barkham Rectory, Wokinghain A. F. M. Downie, Esq., Alton, (2 copies).

Thomas Dreweatt, Esq., Norfolk Lodge, Speen.

Frederick Ellen, Esq., J.P., Andover.

Sir John Evans, K.C,B., D.C.L., LL.D., F.R.S., F.S.A., Nash Mills, Hemel Hempstead.

J. Meade Falkner, Esq., The Divinity House, Darham.

Thomas W. Fielder, Esq., Enborne House, Newbury.

The Rev. A. T. Finch, Kingsclere Vicarage, Newbury. 
vi.

The Rev. John Lomax Gibbs, Speen House, Newbury.

Capt. W. H. H. M. Gipps, (lst. Hants Art. Vol.), Son thampton.

Frederic Goodenough, Esq., Strathmore, Caversham, Reading.

John Graves, Esq., Hydropathic, Kilmalcolm, N.B.

The Rev. H. B. Gray, D.D., Bradfield College, Reading.

The Rev. Canon Greenwell, D.C.L., F.R.S., F.S.A., 27, North Bailey, Durham.

Henry Hammans, Esq., J.P., Clatford Lodge, Andover.

G. T. Harper, Esq., (V.P.Assoc. Chambers of Commerce), The Gaer, Winchester.

Mrs. Richard Hickman, Newbury.

William Holding, Esq., D.C.L., J.P., Elm Grove, Kingsclere.

Henry Holmes, Esq., Ald., 20, St. Lawrence Road, North Kensington.

The Lady Louisa Howard, Hazelby, East Woodhay.

John Hulbert, Esq., 10, New Square, Lincoln's Inn.

Wm. Henry Jacob, Esg., J.P., 27, Christchurch-road, Winchester.

A. F. Jeffreys, Esq., M.P., Burkham House, Alton.

The Rt. Hon. Sir Francis H. Jeune, K.C.B., Arlington Manor, Newbury.

Lady Jeune.

Cumberland Jones, Esq., Barrister-at-Law, Elm Green, Cirencester.

Professor T. Rupert Jones, F.R.S., F.Gr.S., 17, Parson's Grreen, Fnlham.

William Keep, Esq., Ferrises, Woolhampton, Reading.

Charles E. Keyser, Esq., M.A., F.S.A., Aldermaston Court, Reading.

Mrs. Kingsmill, Sydmonton Court, Newbury.

The Very Rev. G. W. Kitchin, D.D., F.S.A., Dean of Durham, Deanery, Durham.

Thos. F. Kirby, Esq., M.A., F.S.A., Winchester College, Winchester.

Montagu G. Knight, Esq., J.P., Chawton House, Alton.

H. C. Knowles, Esq., Glebe House, Sherborne Lane, London, and Linkenholt Manor, Hants.

Miss Lachlan, 24 Palace Court Mansions, Kensington (3 copies).

The Rev. F. G. Lee, D.C.L., F.S.A., 22, Earl's Court Gardens, Kensington.

F. Quekett Lonch, Esq., The Hayes, Donnington, Newbury.

Anthony Story Maskelyne, Esq., Public Record Office, Chancery Lane, London.

Henry Merceron, Esq., 31, Inverness Terrace, Hyde Park.

Archibald Milman, Esq., C.B., Speakers Court, Palace of Westminster.

Mrs, Milman.

The Rev. G. W. W. Minns, LL.B., F.S.A., Weston Cliff, Southampton.

W. J. C. Moens, Esq., F.S.A. Tweed, Lymington, Hants.

Robert Morrison, Esq., Glendale Lodge, Newbury.

Walter Morrison, Esq., 77, Cromwell Road, London, W. (6 copies).

W. A. Monnt, Esq., M.P., Wasing Place, Reading.

W. G. Mount, Esq., Wasing Place, Reading.

Rt. The Hon. the Earl of Northbrook, G.C.S.I., D.C.L., LL.D., F.R.S., Lord Lieutenant of Hants. 
vii.

M. H. C. Palmer, Esq., Newbnry.

George W. Peachey, Esq., Brightwalton, Wantage.

Mrs. Lawson Peregrine, c/o Mrs. Lipscomb, 40, Everstield Place, St. St, Leonards-on-Sea.

Dr. G. V. Poore, Priory Lodge, Andover.

Melville Portal, Esq., Laverstoke, Whitchnrch, Hants.

Sir Wyndham S. Portal, Bart., Malshanger, Basingstoke, (2 copies).

William W. Portal. Esq., Southington, O verton, Hants.

John Porter, Esq., Park Honse, Kingsclere.

The Rt. Hon. the Earl of Portsmoath, Hnrstbonrne Park, Whitchnrch, Hants.

Edward Power, Esq., Watership, Newbury.

Mr. W. J. Prior, Victoria Honse, Kingsclere, (2 copies).

John Rankin, Esq., J.P., (Mayor of Newbnry), Dalriada, Newbary.

Colonel H. M. Ridley, Maperton, Wincanton, Somerset.

J. A. Kntherford, Esq., Whiteoak, Highclere Park, Newbury.

The Rev. E. H. Rycroft, Highclere Rectory, Newbary, (2 copies).

Frederick Schuster, Esq., Oaklands, Alderley Edge, Cheshire.

The Rev. J. E. Sewell, D.D., Warden of New College, Oxford.

Miss Sharp, Ufton Court, Reading.

Mrs. A. E. Shepard, 6, Ridgeway Place, Wimbledon.

W. S. Silver, Esq., Letcombe Manor, Wantage.

The Rev. O. E. Slocock, Goldwell, Speen, Newbnry.

Lt. - Col. E. J. St. John, Slinfold, Horsham, Snssex.

Messrs. B. F. Stevens and Brown, 4, Trafalgar Sqnare, London.

Thomas Stopher, Esq., J.P., Fair Lea, Winchester.

A. Stott, Esq., Twinley, Whitchnrch, Hants.

Christopher W. Strange, Esq., Padworth, Reading.

A. K. Tnll, Esq., J.P., Crookham Manor, Newbary.

The Rev. J. L. Tnrbntt, Midgham Vicarage, Reading.

Herbert C. Tarner, Esq., 30, Market Place, Reading.

The Kt. Hon. Visconnt Valentia, M.P., Bletchington Park, Oxfordahire.

R. H. Valpy, Esq., Enborne Lodge, Newbnry, (2 copies).

Miss Vincent, Donnington Dene, Newbnry.

The Kev. E. M. Walker, Library, Qneen's College, Oxford,

Wm. Thorn Warren, Esq., 42, Christchurch Road, Winchester.

Mrs. Webley-Parry, The Cottage, Backlebnry, Reading.

His Grace the late Dake of Wellington, Stratfieldsaye, Mortimer.

Mrs. White, Bredfield House, Woodbridge, Suffolk.

The Rev. Samner Wilson, Preston Candover Vicarage, Basingstoke.

The Rt. Rev. The Lord Bishop of Winchester, Farnham Castle, Sarrey.

The Most Hon. The Marqnis of Winchester, Amport St. Mary, Andover.

T. Cato Worsfold, Esq., Addison Honse, Balham Hill, Snrrey. 


\section{INTRODUCTION.}

The position which the history of the village commune at present occupies in the field of historical research is of itself sufficient inducement to bring to public notice the following material for the illustration of the social relations of the agricultural classes in North Hampshire during the latter half of the sirteenth century, which furnishes a vast store of new, important, and interesting matter.

Much has already been published with respect to our primitive agricultural institutions, and many surveys, court rolls, and extents of manorial property at this period are to be found in the Public Record Office and elsewhere. We however, possess very few, if any, original returns relating to the little known system of Purveyance, which are so trustworthy to a unique degree in their details as the document on which we are about to treat, or afford so much statistical and local information relating to the various parishes comprised within its survey.

This remarkable and curious record, which the writer discovered amongst a mass of theological literature presented to the Church of Whitchurch, Hants, by the Rev. Joseph Wood, a vicar of the parish in the early part of the last century, ${ }^{*}$ consists of a complete list of the owners and holders of land in a group of North Hampshire villages in the year 1575,-17th Elizabeth, assessed for the purveyance or furnishing of certain provisions

* It is due to the Rev. J. H. Hodgson, late vicar of Whitchnrch, to express the writer's great obligation for the facility kindly afforded him of transcribing this interesting record. In the Vestry of the Church there is a marble tablet commemorating the Founder of the Library, the Rev. Joseph Wood, which bears this inscription:- "Here lye the remains of Mr. Joseph Wood, the late worthy vicar of this parish, whose piety towards God, charity to the poor, and uncommon benevolence and good nature justly gained the love and esteem of all men. By the assistance of Queen Ann's Bounty he angmented the Vicarage with a Rent-Charge of thirty-three pounds ten shillings and eight pence per annum for ever. And left a handsome library, of Books for the use of his successors. He died February 27, 1731, aged 78." 


\section{A ROYAL PURVEYANCE IN THE ELIZABETHAN AgE.}

for the royal household, to be supplied partly in money and partly in kind: at an appraised valuation.

This system of purreyance (purveance, a finding) - a prerogative formerly enjoyed by the reigning sorereign of purchasing provisions and other necessaries in preference to all other persons, is one that has been scantily dealt with in connection with local history. It may therefore be well to enter into some little detail, in order that we may better understand its application to the district with which we are more particularly concerned.*

In the simplicity of older times, when gold and silver were scarce, the household of the king was supplied by provisions furnished from his demesnes. By degrees the servants here employed obtained a fixed tenure of the estates, rendering certain services and supplying certain provisions. Many lands were from time to time granted on condition of yielding such supplies, but these reservations were small, and many of them only to be rendered when the king travelled into the country where the lands lay. In some, special care was taken that he should not make this service burdensome by coming too often, as in the case of William of Aylesbury, who held lands in this manor by finding (amongst other things), three eels for the king, when he should come to Aylesbury in the winter, or two green geese in the summer; but this was not to exceed three times in the year. The town of Yarmouth was bound to send to the sheriffs of Norwich a hundred herrings, which were to be baked in twentyfour pies or pasties, and thence delivered to the lord of the manor of East Carlton, who in turn was to convey them to the king. They were formerly sent to the clerk of the kitchen's office at St. James's; but the pies could never have been of much source as provisions, unless they were made differently from what they usually were, or our ancestors had stronger teeth and stomachs than we have. In 1778 the Sheriffs of Norwich attended with them in person, and claimed certain allowances in return out of the king's kitchen, but no precedent appearing of these things ever having been delivered, they were refused.

* Fabian Phillips, an ardent loyalist, and a steady defender of prerogative and old customs, wrote a long treatise or parveyance soon after its abolition in 1661. In this will be found many curious particulars, mixed with many absurditics. He finds purveyance in the Book of Genesis, in the honseholds of David and Solomon, traces it through all the quarters of the globe, deriving its institution in England from the Romans, and observes that it was continued here by the Saxons and Danes. 
These supplies for the royal table must often have failed. In aid of them, a market for provisions was constantly kept at the palace-gate wherever the king was. This was superintended by an officer called Clerk of the Market of the King's house, who was to burn all false weights and measures, to precede the King in his progresses, and warn the people to bake and brew, and make provision agrinst his coming. He was also, by the oaths of twelve men, to set the prices of provisions, beyond which no person attending the court were to pay.

But to ensure the supply of the King's house, the crown was possessed of this prerogative of purveyance and pre-emption, which was intrusted to officers called purveyors. They were in early times appointed by the treasurer of the household, by warrant under his seal, directed to the clerk of the Crown in Chancery, who made out their commissions. These commissions were sometimes under the great, sometimes under the small seal, but in later times under the great seal only, and were usually granted for six months, at the expiration of which time they were returned to the Board of Green Cloth, when the treasurer of the household either superseded them and directed them to the clerk of the crown to be renewed, or granted new warrants.

At a period when the court removed from one place to another so frequently as it used formerly to do, and when markets were few, and provisions much less abundant than they now are, these officers were particularly necessary. But vested with the powers of an acknowledged prerogative in the days when people were little able to contend even with unjust exertions of power, it is not to be wondered at if purveyors abused their authority.

Religious houses were not exempt except by charter, and the visits of our kings and queens may be evidenced as a sort of purveyance. The great fish-pond at St. Alban's was the occasion of many of these royal visits, which were so expensive to the Abbey that they drained and filled it in to get rid of these troublesome guests.

This privilege of purveyance seems always to have been considered an intolerable grievance; and about forty statutes were passed upon the subject, many of them like all the important early statutes, being a re-enactment of those preceding. Some of the most stringent occur in the 36th year of Edward III. The parliament of that year said to have been held for the honour 
and pleasure of God, the amendment of the outrageous grievances and oppressions done to the people, and the relief of their estate, after a general confirmation of previous statutes, immediately proceeds to enact fire statutes on the subject of purveyance. These statutes confirm the exercise of it to the king and queen, and provide that for the future the heinous name of purveyor be changed to that of achatour, i.e. buyer. They forbid the use of force or menaces, and direct that where purveyors cannot agree upon the price, an appraisement shall be made, with other regulations. The provisions of these statutes are very full and satisfactory, but they appear to have wholly failed in their operation. Other statutes were passed, but without effect. Several of the charges against Wolsey were the exercise of purveyance on his own behalf.

In the time of Queen Elizabeth, two attempts were made in the same year by the Commons to regulate the abuse of purveyance. The Queen was extremely indignant at this, and desired the Commons not to interfere with her prerogative. In the early years of her reign the Queen appears to have employed this prerogative for the purpose of victualling her navy. She afterwards revoked the warrants issued for that purpose, and designed likewise to have taken away the commissions relating to the provision for her own household, some counties having agreed some time after to yearly furnish oxen, calves, muttons, poultry, corn, malt, and other provisions at a certain rate, to get rid of the collectors-a kind of vermin the Queen called harpies.

These compositions for provision of the royal household, of which we now furnish a complete example, were made by the justices of the peace in each county upon agreement with the officers of the Board of Green Cloth, at such rates and prices as were agreed between them. The difference between the price and the value at market was raised by an assessment in the county, and paid to the owners of the goods, but copyhold estates and small freeholds usually paid nothing towards these provisions. A parish thinking itself over-rated as to quantity to be served, appealed to the Green Cloth, from whence an order was sent to the Quarter Sessions to examine into it. The royal prices were far short of the market rates, and taking the county of Middlesex as an example, the difference in favour of the crown on the articles furnished amounted to nearly a thousand pounds, which would represent a very considerable sum according to our present standard. 
The cattle supplied under these compositions were kept in certain pastures belonging to the Crown, appropriated for that purpose; amongst them were the royal park at Windsor, the King's meads at Reading, the Creslow pastures in Bucks, Deptford, and other convenient and rich feeding grounds.

During the first Parliament of James the First, Sir Francis Bacon, on presenting a petition to the King, made his famous speech against purveyors, which forms a sort of compendium of the heary charges made against them. After a proeme, in which he soothes the royal ear with that flattery which was so acceptable to the Scottish Solon, and interlarded with those quaint latin quotations in which the learned king so much delighted, he tells him that "there was no grievance in the kingdom so general, so continual, so sensible, and so bitter to the common subject, as that he was then speaking of, that they do not intend to derogate from his prerogative, nor to question any of his regalities or rights; they only seek a reformation of abuses and a restitution of the laws to which they were born. $\mathrm{He}$ explains that the purveyors take in kind what they ought not to take; they take in quantity a far greater proportion than cometh to the King's use, and they take in an unlawful manner."

We have an illustration of these charges in the case (3rd. Jac. 1.), of one Richards, a Purveyor, who made a curious confession of the rogueries practised by him and his tribe. $\mathrm{H}_{e}$ employed several hands. They charged ten times the quantity wanted, sold the surplus, and shared the money. They went to the most remote places to take their purveyance, in order to induce the people to come to a composition. They conspired with the high-constables to charge more than enough, and took half the money of them, but got receipts for the whole, the constables taking the rest. The clerk of the market set the prices under the value, and shared the gain. This confession did not save him; he was sentenced to stand in the pillory at Westminster, Cheapside, and three markettowns in Devonshire, and three in Somerset; to lose one ear in Dorchester, the other at Wells; to ride on a horse with his face to the tail, and a paper pinned on him expressing his crime; to pay one hundred pounds fine, and to be imprisoned during the King's pleasure. Several negotiations took place in that reign for the purchase of the prerogative of purveyance, but nothing was done.

During the reign of Charles I., although many efforts were 
made to put a stop to the illegal practices carried on under the name of purveyance, this does not appear in the list of grievances complained of in the famous "Petition of Rights"-a Bill which has been called England's Second Great Charter. On the strength of signing this document which enacted that no taxes should be levied without the consent of Parliament, that no one should be detained in prison without a trial, and that no soldiers should be billeted in private houses, Charles received a generous grant from the Commons. He soon, however, broke all his promises; and when the Commons complained, he dissolved Parliament once more. Nor does the fatal and ever-to-be remembered "Remonstrance" which the Commons presented to the King, 1 December, 1641, although consisting of no less than 206 articles, make any reference to the subject of purreyance and compositions for the provision of the King's household, but only that the people were vexed and oppressed with purreyors and clerks of the nobility. Neither in the nineteen propositions of peace, in June, 1642, was there anything proposed for the taking away of the royal purveyance and compositions, or in the treaties at Uxbridge and the Isle of Wight.

Under the Commonwealth it fell into disuse.

On the Restoration, letters were written to the counties of Oxford, Berks, Wilts, and Hants (and probably to all other counties), offering them the choice of allowing the King to take his pre-emption and purveyance, or to pay the compositions. These counties chose the latter, but the whole was soon after put an end to by the Act, 12 Car. ii., c. 24 , which amongst other grievances abolished this heavy one. In lieu of this branch of the prerogative the King received a certain amount payable on excisable liquors. Probably in the earlier periods of our history the existence of purveyance was almost necessary for the support of the royal household, especially during the progresses which were then so frequent. This seems almost a necessary inference for its continuance in spite of so many attempts made to suppress it. Even after its final abolition by the statute of Charles II., several temporary statutes were passed, in that and the succeeding reign, for its partial revival on the occasion of royal progresses. On behalf of the navy and ordnance, a statute to that effect occurs so late as 11 and 12 Will. iii.

Thus have we taken some view of the rise, progress, and extinction of a system which existed for ages, without producing 
to the crown a return at all adequate to the burden it imposed on the subject.

Although it may possibly be said this register presents no feature of striking novelty to those who are familiar with documents of this description; yet the minute details given in this assessment, forming in fact, a complete terrier and directory of the inhabitants of these villages in the period alluded to, are by no means devoid of interest and historical value. Indeed, records of this class appear to be deserving of more attention than they have hitherto received from those who desire to obtain official and therefore correct information as to the social condition of the agricultural classes in past ages.

To the student of family history and personal status, this enumeration of the many owners, tenants, and tillers of the land in the golden days of the most notable of our Tudor Queens must be of considerable value and interest. Particularly to our American friends, many of whom may trace back their lineage to the old homesteads in these pleasant Hampshire villages which their forefathers, yeomen and free-born subjects, left "for conscience sake" in the seventeenth century, and assisted in founding a community in New England, stamped so strongly with the impress of their integrity and enterprise that two centuries and a half has not effaced or dimmed its charaeter.

We ean also discern from this record the early practice and the gradual improvement of husbandry; we can also perceivo and comprehend the then system of agricultural tenure, the mode of distribution of the land itself, and trace up to a period extending to the Norman dynasty, the names of many old yeomen families, who, in several cases have left behind them direet representatives at the present day.

The parish or manor was formerly divided into four portions: first, the lord held together with his feudal rights over the whole except the glebe of the parson or impropriator, a demesne which he eultivated by his bailiff : secondly, there were the small estates possessed by the freeholders, who paid quit-rents: thirdly, there were the tenements and lands of the eustomary tenants; and lastly, the waste or common over which the tenants had the right of pasture, and somotimes of turf.

From the regular division of the manors in this North Hampshire district, as elsewhere, it is shown that many of them were 
formerly the property of one lord, and that their disposition was a matter of choice, and not of necessity or accident. The valleys are almost without exception intersected longitudinally by rivulets, and the sides of these bournes being the most eligible situation for buildings, were of course selected for the houses of the villagers. Consequently the shape of the manors became a narrow oblong: each manor required water and meadow ground, and also, as coal was very little, if at all, in use at this time, wood for fuel. The meadow ground very properly was situated near the river, and the woods on the tops or sides of the hills, and the woods which remain evidently show that the summits of the hills were originally woodland. Thus the apportioning of these woods, low ground, and water, accounts for that long narrow form which may be observed in many of the manors of this district, and which are often found stretching across from the brooks and rivers to the former woodland country. Thence another manor from the ancient woodland to the next river or brook, extending five or six miles in length, and from half-a-mile to a mile in breadth, including those downs which were formerly covered with wood at one end, and meadow ground and water at the other. Hence arose the favourite idea among the down farmers that no farm could be advantageously disposed for the general circumstances of that country unless it had water-meadow at one end, and maiden down at the other.

The manors were therefore naturally divided into long narrow strips from river to wood, with the right to use of both, and as such appear to have been a combination given by the original granters, or superior lords, to the grantees or inferior holders. While the system of common-field husbandry existed in its original state, and every yard-land had its farm-house, its yard for cattle, its barns and its stables, such an arrangement had its advantages as well as its inconveniences.

Apparently, the application of the land in North Hants was almost uniform. The common meadows, of which the greater part were watered, immediately adjoined the river, the houses and small inclosures as near to it as possible. Next followed the arable, or "errable" in Elizabethan spelling, until the land became too steep or too thin to plough, and then the sheep and cow downs, at the extremity, and frequently the woods of the manors in the opposite bourne. In some instances, particularly where the bournes approach their junctions, and sometimes at the heads of the streams 
where the water can be easily crossed, the lands belonging to each manor are partly on one side of the village and partly on the other, whereby the occupation of the open fields was rendered more convenient. But these instances are comparatively few.

The introduction of the ancient common-field system of agriculture, under which the open fields were the common fields-the arable land of a village community, and were practically the same in their general features throughout the country, seems to have been very slow and gradual. The dispersed situation, and smallness of the strips or bundles of land indicating that the ocoupiers began tilling with a single acre, being one day's work for a plough, or, perhaps, only half-an-acre each. * But as a want of corn increased they gradually enlarged their tillage, until they had cultivated all that was required for that purpose. Those parts of the lands which were not fit for the plough or were at a distance from home, being left in a constant state of commonage, but by mutual consent the cattle were kept out of the cultivated parts till the harrest was finished. By the same kind of mutual agreement, they shut up, and in some cases inclosed, such parts of their common pastures as were most proper to mow, dividing them into certain specific quantities, either by land mark or by lot, and suffering the common herd of cattle to feed them again, from the time the hay was carried off till they were "hained" + or laid up for a new crop. These mutual arrangements, originally founded in necessity, became, when approved by the lords, and observed for a lengthy time by the tenants, what is called "Customs of Manors," and constituted the very essence of the "Court Baron or Manorial

- The acre was usaally considered 40 poles long and 4 rods wide, or a farlong or furrow long in length. The farlong cannot, however, be taken as a fired measure of area. It was often used for an allotment or section of an open or conmonable piece of land held in severalty, whatever the dimensions. Nor must it be confonnded with a "ferling" of land, which in modern court rolls has generally become a "farthing" land. In fact, the acre, although a term now in use, and its extent definitely settled by statute, had not formerly any certain limits, although there was a general and commonly received idea as to its proper size, bat as the virgate or yerde both varied as to the number of acres they contained, so did the acre itself vary, mach in the same sort of way as a foot did, until au average was agreed upon and definitely settled.

+ In the interesting case of Hobbs $v$ the Corporation of Newbury heard before the Recorder, in Febraary, 1888, in which the writer was the principal witness, he explained to the Court that the word "hayned," or "hained," is an old Engliah term signifying to lay in ground for hay by the removal of the common herd of cattle froun pastare land, and so used in the ancient records of the Court Baron, which, with the original charter of Queen Elizabeth were prodnced. It is satisfactory to add that the rights of the townspeople were maintained by the evidence these old documents afforded. 
Baron," by which both lords and tenants were, and are still legally bound; and of which, though the lord or his steward be the judge, the tenants are the jury.

In general there was in each manor one great farm called the lord's farm, which usually had its land in severalty and distinct from the tenants. The rest of the manor, called the tenantry part, was divided into small copyhold tenements or farms called "yardland, * lying dispersedly and uninclosed in lots and furlongs; each of which was originally of nearly equal value, and enjoyed equal rights of commonage. These tenants sent their sheep to one common flock and their cows and plough oxen to a common herd, respectively under the care of a common shepherd and herdsman. The value of the virgates or yard-lands and the number of acres they contained varied considerably in different parishes, and this document furnishes us with information in this respect which may be a useful addition to that obtained from other counties. Here as elsewhere the normal area was about 30 scattered acres-10 in each of the three fields, but at Southanton or Southington the yardland was $37 \frac{1}{2}$ acres, at Woodhay 60 acres, at Cold Waltham, now North Waltham, the virgate or yard-land varied from about 32 to 50 acres, while at Whitchurch it contained 20 acres. The quantity varying according to the quality of the soil or its productive value.

It may here be explained that in English the virgate was commonly called a yerd, or yard land, but both this English term and the Latin one virgate are evidently of very different origin. The word yard or rather yerde is of Saxon origin. It is, however, different from the word yard, the measure of length, although that is also derived from the Saxon, or rather is a continuance of the old Saxon word yerd. The superficial measure a yerde or yard is derived from the Saxon yearde, and means a certain extent of land. The word virgate is made to mean the same, but as we have observed is rather derived from the nature of the holding than the extent of the land. These small estates were generally, it may be said universally, held under the lord of the manor, either directly as grants from him, or immediately through him by the authority of his court; and the method of giving seizin or possession of them was by means of a rod which the seneschal or steward of the manor bore as his sign of office, and by touching which the tenant was

* The yard-land consisted of sufficient land for a plongh of oxen and a yard to winter them, each being occupied by one tenant, and enjoyed equal stinted rights of common. 
admitted to possession by favour of the lord. This rod being called in Latin virga, the land to which possession was so given was styled virgata terra, literally land by the rod, or a rod, and thence a rood of land. It is in this sense that Goldsmith in his Deserted Village makes use of the word when he writes,

\section{And every rood of land maintained a man;}

for a rood in its common acceptation is only a quarter of an acre, which would never maintain a man; but a rood as explained above, meaning a yard or yard land, which, as we have seen in North Hampshire contained from about 20 to 60 acres, was a very adequate quantity for maintaining well, especially in former times, a man and his family. According to the Monasticon a virgate of land was one eighth of a hide, which usually contained 120 acres, but Spelman and Somner both say a virgate consisted of 15,20 , 24 , or 30 acres; so that, as we have said, it contained different quantities in different places.

The common sheep down was open for the common flocks during the summer and autumn, and the unsown or summer-field was also open until it was ploughed for wheat: after that, the sheep had only the down till the harvest was over. When the corn fields were clear, the flock had the run of these fields and the downs till the winter obliged the owners to give them hay, up to this period they were folded in the arable fields in a common fold, but when they began to eat hay, every commoner found his own fold and his own food, a common shepherd feeding and folding the whole.

Early in May the common herd of cows began to feed the cowdowns, usually on Holyrood Day, and finished when the fields were clear of corn. At the beginning and end of the season they were driven to the common in the morning, and brought back in the evening; but in the heat of summer they were only kept on the down during the night. When the stubble fields were open the cows had a right to feed them jointly with the sheop, and if they were common meadows, whether watered-meadows or not, they had an exclusive right to feed them till the end of the commoning season-usually St. Martin's day, 11th November, O.S., when the owners took them home to the strawyards. The cow down when the cows left it to go to the stubble fields became common for the sheop flock during all or a certain part of the winter, when it was again laid up for the cows. Orer the un- 
stinted commons continual rights of pasture extended, directed by a general law decided by and obligatory on the whole community.

The North Hampshire landholders were evidently corn farmers, and in these returns we find a large preponderance of arable. There were no means of transport, no passable roads, generally no navigable rivers, no canals. Each district was necessarily selfsupporting, raised its own corn, fed its own hogs in the woods, and made by women's labour its own warm clothing. The home market was the only market. Landlords and farmers were content to raise corn, because it paid as well if not better than anything else. The government was contented, because the people were employed and fed. But in this day it is not easy to picture to ourselves, or even to imagine, the hardness and earnestness of the life led by these simple North Hampshire folk in the 16th century. A rude farmhouse mainly built in timber frames, plastered inside and out with cob, locally called "wattle and dab," composed of chalk malm and clay mixed with chopped straw, except on the ceiling where hung the bacon rack, protected the family from summer's heat and winter's cold. The house contained none of the equipments which domestic economy now considers indispensable, none of the comforts and adornments which have now become common necessities even in the humblest dwelling. The furniture was of the simplest and crudest kind-low benches with chests under them running round the walls, while a rough oak "settle" to keep off the piercing draughts of winter and an unwieldy table formed the principal and movable items in the common living room. A wide chimney bore from a broad hearth a large proportion of the heat created by a lavish use of wood fuel. The farmer's joys were simple, his pleasures few. At the same time, the rude homestead was an inclosed spot, sacred against all comers, the home which came to be properly called an Englishman's castle, the first step in the history of real property law.

The position of these small proprietors or free-born yeomen, who cultivated their forty, fifty, or eighty acres of land, is well represented in the following description of an English yeoman, by Bishop Latimer, in a sermon preached before Edward VI. in 1549:-

"My father was a yeoman, and had no land of his own; only he had a farm of three or four ponnd by the year at the nttermost; and hereapon he tilled so much as kept half-a-dozen men. He had walk for 100 sheep, and my mother milked 30 kine. He was able and did find the King a 
harness with himself, and his horse, when he came to the place that he should receive the King's wages. I can remember that I buckled his harness when he went into Black Heath field. He kept me to school, or else I had not been able to have preached before the King's Majesty now. He married my sisters with $\mathfrak{£ 5}$, or twenty nobles a-piece, so that he brought them ap in godliness and the fear of God. He kept hospitality for his poor neighbours, and some alms he gave to the poor; this he did on the same farm where he that now hath it payeth $£ 16$ a year or more, and is not able to do anything for his Prince, for himself, or his children, or give a cup of drink to the poor."

The cottages of the cottars or labourers, each with its garden and curtilage, were built on the bare earth, with upright posts, wattled with willow or hazel rods, and smeared inside and out with clay, or cob, and not provided with an outer finishing coat of roughcast, as was the case with his master's dwelling. Half-way up was a rude floor made of unhewn poles, and reached by a ladder. The whole was thatched with straw, reeds, or broom. Sometimes the hut was wholly made of mud or clay kneaded with a few sticks to give it cohesion. Close to each cottage or farmhouse was the mud heap, streams from which in rainy weather poured down to fertilise the lower meadows. In many of these huts, however, cloth and homespun linen were woven, and when collected by the chapmen, of which we have a reminiscence in the local name of "Chapman's ford," were sold at the great fairs of Weyhill and Winchester. The only building of any pretensions was the parish church, in which most of the local business was transacted, when religious services were over, and even produce was stored, as we remember to have seen in one of these North Hampshire churches not many years ago.

Under the common-field system little or no variation of crops could take place, wheat, barley, and oats were the principal grains thought of ; and the first object always was to get the wheat crop round as often as possible, whether the land was good or bad, deep or shallow. The general course of cultivation was 1 . Wheat; 2. Barley or Uats; 3. Fallow. *

The peculiar disadvantages of this form of cultivation namely, the obligation of ploughing and cropping all soils alike; the almost total preclusion that a common flock made to any improvement in the breed of sheep stock, the difficulty, and in some instances, the impossibility of raising sufficient hay or green winter food for the

"It may be observed that the word "fallow" bears two significations, and one was either a frequent plonghing of land to make it lighter, and clean from weeds when it had become foul by repeated crops, or, a mere rest to the land when it is exhansted. The end in view however, being the same in both cases, viz., to enable the land to bear a fresh succession of crops. 
flock; and particularly the very great expense of occupying lands in dispersed situations, gradually led to the extinction of this mode of farming. Nearly 4,000 Enclosure Acts were passed between 1760 and 1844, and thus it will be readily understood how generally prevalent was this ancient communal system so late as the days of the grandfathers of the present generation.

Before proceeding to the text of the survey, it may be well to say a few words respecting the parishes and tithings to which it extends.

The particulars recorded comprise the following parishes and tithings in the Hundred of Evenger.-Whitchurch, including Charlecott and Colhenlye, Freefolk Priors and Manor, Hurstbourne Priors or Down Husborne, St. Mary Bourne, Stoke, Weeke, Egberry, Binley, Woodhay, Ecchenswell or Itchenswell, Ashmansworth, Highclere and Hawclere, Burghclere or Borrowclere, Baghurst or Baughurst, and Newtowne. Hundred of Chutlye.-Monk Sherborne, Worting, Lawrence Wotton, Haningand ton, Church Oakley. Hundred of Kingsclere.-Earlstone, Edmonstrop Launcelewill, Edmonstrop Beenam, Frobury, The Lordship of Kingsclere, Parsonage, The Guildhable, Hanington, Launcewell or Launces, Sandford and Clere Woodcott, Ewhurst, Wollferton or Wolverton, Sydmonton, Lychfeilde, or Litchfield, North Oakley, and Plaistowe. Hundred of Pastroe.-Crux Easton, Faccombe, Lynchenholte or Linkenholt, Conholte, Woodcott, Ffarnehamdeane or Vernham Deane, Hurstbourne-Tarrant or Up-Husbourne, Tangley, and Coombe. Hundred of Overton.Broadlye now Bradley, Cold Waltham now North Waltham, Deane, Quidhamton, Ashe, Polhampton, Southanton or Southington, Norrington, Laverstocke, Tadley, and Overton. 


\section{ARTICLES OF AGREEMENT.}

The following are the Articles of Agreement made between the Officers of the Board of Green Cloth and certain Justices of the County of Hants acting on behalf of the said shire:-

\section{HAMPSHIRE.}

A Coppie of the Articles of Agreement and Composition had and made the x. . . . Ano svijo Regine Elizabethe betwene the .. Honorable Sr. ffancis Knollys, knight: * Treasurer to her maties most hone household and Sir. Jeames Crofte $†$ knight, Comptroller of the same and other her officers of her greene clothe on the behalfe of her matie: and certeine of the hone and worpll of Hampshire.

The share to be devided so as in that iiij dayes the whole may be deliuered with directing how many hundreds shall bring in every of the said dayes.

ffirst that foure hundred quarters of good and sweete wheate shal be delivered at Readinge in the County of Berks for the Queenes maties use the $x^{\text {th }}$ day of November or within foure dayes after at the uttermost, at vj viiid the quarter paying allwayes for the owlde when the new cometh in.

* Sir Francis Knollys, a zealons partisan of the Reformation, a faithful friend and wise counsellor of Queen Elizabeth. On her accession he was made a privy coancillor, and vice-chamberlain and treasarer of the household. He was also employed in several important matters of state. He was steward of the borough and lordship of Reading, and of the estates formerly belonging to Reading Abbey, and where he entertained Queen Elizabeth for some days in the year 1572. He married Catherine, daughter of William Carey, esquire of the body to Henry VIII., by his wife, Mnry Boleyn, sister of Queen Ann Boleyn. He died in 1596, and was buried at Rotherfield-Greys, the family seat near Henley-on-Thames.

$\dagger$ Sir James Crofte or Crofts. Lord Depnty of Ireland and Controller of the household. He died in 1591, and was buried in Westminster Abbey. 
Itm that thirtie good fatt stirtes * of the adge of one yeare and upwards shalbe deliuered at the courte gate the ffirste of November at iij viiid the peece.

Itm that three hundred good and fatt lambes shalbe deliuered the courte gate the xth of June at xijd the peece.

Itm to be deliuered at Odiham, Alton, and Basingstoke within $\mathrm{x}$ dayes after warninge given to the Constables of the Towne and hundred of Odiham: of Geese corse ¥ twenty dozen; Capons corse twenty dozen: pullets corse ffiftie dozen and hens corse thirty dozen.

(The warninge would be given 20 dayes at the leaste to the Constables of the hundred that shalbe assigned to deliver at eache of the severall places and no reason to trouble the townes aforesaid but only for ther owne ptes: this may be done by certifying the officers what hundreds shalbe assigned to every place.

Itm that ready money shalbe paide for all the p'revissen upon the recoipt therof.

Itm if there be iuste cause of mislicking of any of the previssens and the same declared by iiij indifferent men in writing under the handes wherof $i j$ to be named on the behalfe of the Queene and some of her household and of $i j$ of the bringer or bringers of the same; that then they shall forfeite to the Queenes Maties use for every such quarter of wheate iiis. iiijd. for any stirte $\mathrm{ij}$, vjd. for any lambe xijd. ffor every goose capon pullett and henn iiijd. to be defaulted by the Cofferer for the time being of the price or prizes of the reste of these kindes that shalbe licked and receved, and the wantes of every kinde to be supplyed within xiiij dayes at the furtheste.

* Stirtes or Stirks.-Young Steers.

† The Court Gate of Reading Abbey. At the dissolntion of monastic houses King Henry determined to maintain the Abbey of Reading as a royal palace; and, thorgh it was not often occupied in that capacity, yet we find King Edward VI. lodged there, as "the Kinges Place," in his visit to the town in 1552, and King Philip and Queen Mary in 1554. Camden says, "The monastery wherein King Henry the First was interred, has been converted into a royal seat; adjoining to which stands a fair stable stored with noble horses of the king's." It was an account of Sir Francis Knollys holding the office of steward of the abbey estates that he resided at the mansion formerly the Abbey.

$\ddagger$ Corse or Corsey, i.e. fat. 
Itm that during such time as this composition and order shall take place ther shalbe no maner of purreyance by Comission for any of the kindes above-named . . Queenes most ho: houshould within the said . out of the said shire to any ffaire or market . . owners of the said Cattell dwelling in the . . .

Itn if it shall chance that the said wheate, stirtes, lambes and poultry be not receved to the Queenes Maties use of the bringers of the same to the place before appointed within one daye next after the bringing of the same and offer, made of the same to the Queenes Maties officers of the greene clothe and others to whom it doth or shall appteine that then the Queenes Matie to beare the charges both of the said Cuttell and bringers of the same until such time as they shalbe received.

Itm it is further agreed that if these two gentlemen or any other two Justices of the Peace of the same shire do directe their tresr to the Cofferer of her Maties household for the time being declaring their wantes of all such as do refuse to paye the rate appointed: That then Comission to be directed to two Justices of the same shire authorizing them to take sutch p'portion as it shall seeme good to them, of all sutch as doe refuse.

I $\mathrm{tm}^{\mathrm{m}}$ it is further agreed that upon declaration of good and reasonable matter the penalties before mentioned are to be qualified according to the consideration of Mr. Treasurer, Mr. Comptroller, and others of the greene clothe for the time being.

I $t^{m}$ it is also agreed that upon mislicking any of the kindes of poultry before mentioned by the purveyors: That then it is referred to be brought to the Courte of the shire: the bringers therof $\mathrm{p}^{\mathrm{r}} \mathrm{sently}$ upon the delivery therof at the Courte to have as well as ready money for his said poultrye, as well as the purveyors wages and sallary ffor the carriage thereof, being but iij dayes at the most bringing of there severall carriages.

To the Right Honorable our good Lorde the Marques of Win- 
chester, *, the Earle of Southtn + , the Bishop of Winton + , the Ld. Sandes, $\S$, the Lord Delaware, || Sr Henry Ratcliffe $\mid$, Sr Henry Wallop **, knightes, and other the worpll of the shire.

* John Powlett or Paulet, 2nd marquis of Winchester, son of William Powlett, lst marquis, Lord High Treasurer. He died in 1576, bequeathing his body to be buried in the church of Basing, and ordering that $£ 1000$ should be spent on his funeral.

† Henry Wriothesley, 2nd earl of Sonthampton, ob. 1581.

Robert Horne, bishop of Winchester, 1560-1580.

$\$$ William Sandys, 3rd baron Sandys of the Vyne, where he entertained Queen Elizabeth in 1569. He died in 1623, and was buried in the Holy Ghost Chapel, Basingstoke.

$\|$ William West, knighted at Hampton Coart 5 Feb., 1568, and created at the same time Lord Delaware. This family owned Wherwell Priory, which was granted at the dissolution to Sir Thomas West, Lord Delaware.

I Sir Henry Ratcliffe, born abont 1530. Knighted by the Earl of Arundel, 1553., M.P. for Hants, 1571, and for Portsmouth, 1572-83. Governor of Portsmouth 1571. Succeded his brother as Earl of Sussex, 9 June, 1583. Joint Lord Lieutenant of Hants 1585. K.G., 1589. He married Honora, dau. and sole heiress of Anthony Pound, co. Hants. He died 14 Dec. 1593.

** Sir Henry Wallop, knighted at Basing 1562, was M.P. for Southampton from 1572 to 1584. Vice-treasurer, and treasurer of war in Ireland. In 1591 he entertained Queen Elizabeth, with her court for some days at FarleyWallop. He died in 1599 , and there is a monument to his memory in St. Patrick's Cathedral, Dablin. The name of Wallop is derived fron the manor of Upper Wallop, on the borders of Wilts, which was in possession of the same family before the Conquest. Soon after this period they were created hereditary knights, or baronets ; and for many years bore an active part in the local and general service of the conntry. They were promoted to the peerage in the reign of Geo. I. and Geo. II.; and hold the Earldom of Portsmouth, the viscountey of Lymington, and baronetcy of Wallop.

The following is the inscription on the memorial brass of Sir Henry Wallop in the Cathedral, Dublin :-

"Neare vnto this place lyeth the Worthie Knight Sir Henrye Wallop, of Farley Wallop, in the covntye of Sovtht, in the Realme of England, whoe faithfullye served Qveene Elizabeth in this Kingdome as Vice-Treasvrer and Treasvrer at Warres by the space of $\mathrm{xix}$ yeares and eighte nonethes, and was Ld. Justice within this Realme jointlye with the Lord Chavncellor of this Realme almoste by the space of 2 yeares, in the yeares of ovr Lord God, 1582, 1583, and 1584, in which tinie the warres of Desmond were ended, and his heade sent into England, besides manye other weightie cavses comitted to his chardge dvringe his sayd service, he departed this life the xiv. day of Aprill, 1599. He was sonne and heire of Sir Oliver Wallop, Knight, brother and heire of Sir John Wallop, knight of the moste honora Order of the Garter and Lieftennant of the Castle and Covnty of Grysnes, in France; nephewe and heire of Sir Roberte Wallop, Knight.

" Here also lyeth Dame Katherine, his wife, davghter of Richard Gifford, of Somborne, in the saide Covnty of Sovthampton, Esq.; and Ann, his wife, davghter to Sr William Goringe, of Bvrton, in the Covntye of Svssex, Knighte, who dyed the xvith of Julye. 1599."

"Also, here lyeth Oliver Wallop, yovnger sonne of the sayde Sir Henrye Wallop and Dame Katherine, who was slayne in service against Je movntain rebells ye xvth of Jvne, 1598.

"This inscription was here affixed the vi daye of Marche, 1608, by Sir Henrye Wallop, Knight, sole svrvivinge sonne and heire of the saide Sir Henrye Wallop, deceased, and a fayer monvment hereof placed in the Charch of Basingstoake, in the aside Covntye of Sovtht, accordinge to the appoyntment of ye sayde Sir Henrye, his last will and testament." 
After our partie comendacons according to the contents of your tres ${ }^{r}$ the gent therein authorized by you have concluded with us for sutch sorts of provision for her Maties housholde, and for sutch pportion therof as by our indifferent care with the addition of these instructions wee have thought meete your shire to be apportioned wherupon it remaineth that by your Lordships aforesaid and the reste, the Queenes highness shalbe well satissfied, and your conntry indifferently dealt withall, suche shall cause the paynes on all pts to be thought well bestowed. And so wo comitt you to the tuition of thalmighte from the Courte the xxijth of Marche, 1574.

Yo Lo: to Comande,

fira: knollys: Ja: Crofte: Richarde Warde: ${ }^{*}$, Anthony Crane.

* Kichard Warde. "Cofferer" or Snb-treasurer to the Court. M.P. for Windsor in the Parliaments of 1547-53-53-54-54, and for the county of Berks, in the Parliament of 1571. He was high-sheriff of Berkshire, 33 Elizabeth, 1590. The Wards, a Yorkshire family, were of Hurst in this connty, the manor of which was granted in 1539 to Richard Ward and his wife Ann. In the charch of Harst there is a monument in Parbeck marble with enriched canopy, and panels bearing shields of arms, to Richard Ward, "the Cofferer," and on the npper brass a group representing Warde himself, and his eight sons behind him, all kneeling; and anderneath the epitaph in latin rerses, which has thus been rendered:-

"Life flies, and Ward is dead; bot mourn him not, One who so well has lived, true life has got,

Of honoured race he was, a Christian true,

And God to please, his study all life through ;

So his Lord loved him, and His blessings poured

On all he had,-his home with blessings stored.

To Henry, Edward, Mary, Great Elizabeth,

Sub-Treasurer he was, faithful in love till death ;

Yes, faithful to thens all, and so by each beloved,

Ne'er by base thought of gain for self, or kindred, moved.

Godly he was in life; in death the same;

Through death, true life to him, eternal, came;

And with Colnbra joined him, ne'er to part;

Their grave, their rest, was one, as ever was their heart."

On the left of the monament there is a similar group of females, with evidently the wife of the singular Christian name of Colubra, kneeling also with her eight daughters. A bove is a slip of brass with the words, "Colubra Ward dyed the 14th day of April, 1574." Alse, eldest daughter of IRichard Ward and Colnbra his wife, became the wife of Thomas Harrison, and was the mother of Sir Richard Harrison, the father of Sir Richard Harrison, knight, the ever loyal and faithful sapporter of Charles I. She died in childbed of her first son, and over the inscription on her gravestone is $\Omega$ small brass with the hgure of the poor lady in her bed,-carious as giving the forn and decoration of a bed of that date, with posts and curtains. Thomas Howard, third earl of Berkshire, married Frances, danghter of Sir Kichard Harrison, of Hnrst, and their eldest daughter Frances, became the wife of Sir Henry Winchcombe, 
The Justices in their turn issued the following precept to the High Constables of each Hundred, through the Sheriff of the County, who was the responsible officer:-

A Copie of the Warrant from the Justices of the Peace to the Constables of every division at the time of the assessment for wheat, poultry, etc.

\section{Pastroe.}

We have us co'mended unto you, etc: As well the honorable as other the Co'missioners within the County of South'n considering the great quietnesse that might grow unto the Queenes Maties subjectes within the same in setting downe by order what shalbe yealded out, viz.: of wheate, stirtes, lambes, geese, and poultry of every hundred for the prouision of the Queenes Maties most honorable household: have with great considera'con and ther whole consente assessed the hundred of Pastrowe to deliver at the dayes and times agreed upon, of wheate $x v$ qrters, $v$ lambes, iiij geese, iiij capons, $x j$ pulletts, vij hennes. And that the same may be better accomplished and done with most indifferencye: These shalbe to charge you whose names as heer under written, that you who be together appere before us at Whitchurch on ffriday, the vjth of May next, coming by eight of the clocke in the morning, ther as well to answer us to sutch cawses as we have to deale with you towching the same, as all so sutch articles as heer in we $\mathrm{p}^{\mathrm{r} s c r i b e d}$ unto you.

Imprimis wee will that you certifie unto us in writing the same day and time how many acres of land every p'son hath in his or her occupa'con within your hundred, (the demesnes of every Justice of the Peace where he dwelleth only excepted): with indifferency, viz., how mutch errable, how mutch meadow, how mutch pasture, how mutch woode or waste ground eche holdeth.

Itm that you certifie what parsonages you have within your hundred, the number of acres in gleebe. The

Bart., a descendant of the famous John Winchcombe, better known as "Jack of Newbury," the patriotic clothier. There is a pedigree of Ward, of Hurst, in Ashmole's Berkshire, which shows that Colubra, wife of Richard Ward, was the daughter of William Lambard, of Chertsey, co., Surrey, and Alice, his wife, daughter of Thomas Tasbargh, of Suffolk. 
whole valew and goodnesse of the same, as they be by estima'con in deede. In sutch sorte as is p'scribed unto you by the former article.

Itm it is thought good that no man, that hath not full ij yarde lands in his occupa'con shall yealde any wheate to this prouision. Thus mutch wee thought good to lett you understand that you the better consider how the wheate may beste be reared.

$\mathrm{It}^{\mathrm{m}}$ wee will you to give us in writing how the wheate may best be charged upon the yard land and parsonages w'hout towching (as aforesaid), sutch as have not ij yard lands.

Itm that you certifie unto us, how and upon whom iijs. iiijd. for every lambe assessed within your hundred may beste be leauyed not towching them the poorer sorte.

Itm that you certifie unto us how and of whom the poultry and geese assessed upon your hundred shall beste be leauyed upon sutch as have some tillage, and not charged with wheate, lambes, nor stirtes, etc.

Itm that you wholy together without seperating your selves that no partialytie be used: be at the view of the number of Acres in every man's occupa'con: Dated at Woodcott, * the avth April, 1575.

Your frendes,

William Kingsmill. $\dagger$

John Thornburrow. $\ddagger$

- The old manor-house at Woodcott has long been occupied by the farmer of the lands, but retains some evidences of its former importance. It commands a magnificent view over a wide range of open country. Some years since a priest's hiding place was discorered behind a stack of chinneys, accessible only by removing the floor boards in one of the rooms. A steel kitchen spit, $10 \mathrm{ft}$. in length was also dag ap near the house. A relic of the days when sheep were roasted whole, and of the "fine old English gentleman, who, though he feasted all the great he ne'er forgot the poor."

+ Sir William Kingsmill, knt. of Sydmonton, who was then the owner of Woodcott.

John Thornborongh, Esq., of the family of this name of Thornburgh, $\infty$. York. He was one of the commissioners for musters and for disarning recusants, high-sheriff of Hants, 1578, and is described as of "Shetesden," or as otherwise entered "Spaddesden," co. Hants. Probably Shoddesden, in the parish of Kinpton, near Andover. By Margaret, daughter of Sir John Kingsmill, of Sydmonton, he was father of many children, amongst them Sir John, Edward, Henry, Frances, and Katharine, (who died in 1650), wife to Alezander Dyer. 
To ther frends the Constables of the hundred of Pastrowe, and to John Hellyer, Anthony Boswell, Willia' Temple, Will. Still, Thomas Hellyer, Willia' Deane, and Robert Wadlow, ${ }^{*}$ and to every of the said hundred.

Returne to us at the day this prcept wth you.

$\left.\begin{array}{l}\text { EuEnger } \\ \text { HuNDRED }\end{array}\right\} 1575$ ffor the payment of xxij q'rters of wheate.

\section{WhITCHURCH. $\dagger$}

John Clarke for the ffarme theare Richard Brooke, gent., for the parsanage and other land .

Simon Deane for Mr. Matons ffarme

Robert Cooper for his hould there -

Nicholas ffoster for his hould there -

Thomas Boyett for his hould there -

Winifred Poynter for her hould there

Richard Beanes for his hould there

Roger Rutter for his houlde - -

William Soper for his houlde- -

Mr. Richard Audlye for his farme of

Henleye - - - - -

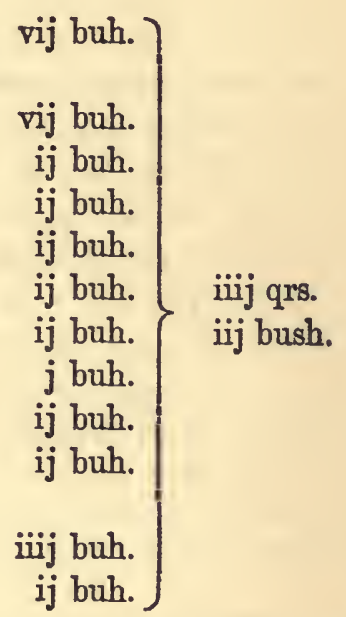

* The name of Wadlow is familiar to the readers of Pepys as that of the Vintner of the Devil Tavern, Fleet Street, who led "a tine company of soldiers, all young comely men in white doublets," at the coronation of Charles II.

$\dagger$ Whitchurch. The manor of Whitchurch, inclading "Frigefolk" was given to the Church of Winchester by Edward the Elder, eldest surviving son of King Alfred. It is an ancient prescriptive borough, and from 27 th Elizabeth antil it was disfranchised in 1832, sent two members to Parliament. The parish comprises the Borongh or Town Liberty, and the four small tithings of Whitchurch Parsonage, Freefolk Priors, Charlcott, and Cold Henley. The churches of Whitchurch, Hurstbourne Priors, East Woodhay, and Overton are mentioned as bestowed on St. Cross in De Blois' charter of foundation.

By his will of 4 Aug., 1503 Sir Reginald Bray gave the manors of Freefolk, East Woodhay, and Quidhampton to his nephew IRichard Andrews, and his wife Elizabeth, with remainder to the heir's male of John Bray. Freefolk manor is a small parish adjoining the tithing of Freefolk Priors.

The Free Chapel of Cold Henley is mentioned in a Compotus for the year 1526. 


\section{Frrefolike Tythinge.}

The manor of ffrefolke in the occupacion of Mr. John Pawlett, Mr. Waiter Lambert, and Mr. Henry Norris - 1

Peter Cropp for his hould there -

Thomas Clarke for his hould there

Christian Mason for her hould there

Richard Cufflye for his hould there

William Sutton for his hould there

Hugh Benham for his hould there

1 quarter

ij buh.

ij buh. iij qrters.

ij buh. $\}$ i buh.

ij buh

ij buh.

ij buh.

ij buh.

iij buh.

Joane Silver for her hould there -

It will be observed that the $u$ is almost invariably ased for $v$ thronghont the MS.

Husborne, Swampton, and Borne."

The La. Oxenbregg for the Manor there

Richard Kingsmill, Esqre, for all the

land he houldeth there - - - iij buh.

William Milles for his hould there - ij buh.

Swithian White for his hould there - ij buh.

Thomas ffisher for his hould there - j buh.

John Beachen for his hould there - $\mathrm{j}$ buh.

Richard Goslinge for his hould there - $\quad \mathrm{j}$ buh.

John Cooper for his hould there - - j j buh.

William Jaques for his hould there - $\mathrm{j}$ buh.

John Braye for his hould there - - iij buh.

Richard Underwood for his hould there $\mathrm{j}$ buh.

John Braye by the Church for his hould $\mathrm{j}$ buh.

John Brexton for his hould there - iij buh.

vj qrs.

ij buh.

Mr. Roger Corham for the p'sonage and

land he holdeth of the La. Oxenbregg xij buh.

Thomas Berklye for his houlde - - ij buh.

Elizabeth Crooke for her houldo - - ij buh.

Jefferie Poore for his hould - - iij buh.

Simon Cooper for his hould - - j buh.

William Silvester for his hould - - j buh.

- Husborne, or Hurstbourn Priory, the Eissebarne of Domesday. One of the gifts of Edward the Elder to the Priory of St. Swithin of Winchester, hence the adjunct Priors is derived. The manor was purchnsed in 1558, from the representatives of Sir John Gates, vice-chamberlain and captrin of the garrd to King Edward VI., (who was beheaded with the dake of Nortlumberland in 
a ROYal PURVEyance in THE Elizabethan age.

\section{STOKE.*}

Richard Wigmore for the lande he houldeth of the Lady Oxonbregge there - - - -

the same Richard for his houlde he houldeth of the Deane of Windsor William Hayes for his ffarme there William Elderwill for his houlde there ij buh. George fficcas for his houlde there $j$ buh. John Rumboll for his hould there $j \mathrm{buh}$. George Rumboll for his hould there $j$ buh.

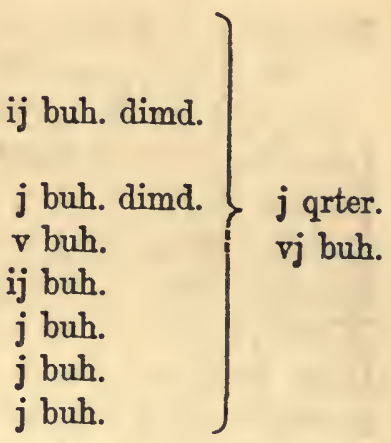

WeEke. $\dagger$

Richard Hayes for his hould there Robert Oxenbregge Esq. for his land there Richard Cooper for his hould there Eliz. Billett for her hould there Thomas Canon for his hould there

$\left.\begin{array}{rr}- & \text { ijj buh. } \\ - & \text { iij buh. } \\ - & \text { j buh. } \\ - & \text { j buh. buh. }\end{array}\right\} \quad \begin{aligned} & \text { ij buter. } \\ & \text { ij buh. }\end{aligned}$

* Stoke tithing lies midway between the villages of St. Mary Bourne and Hurstbourne Tarrant. The name appears to be derived from the Saron stoc a place.

$\dagger$ Weeke or Wyke, contains the several divisions of Upper, Middle, and Lower Week. The name is derived from the Saxon wic or hamlet or settlement. Upper Week is the more important of the three, and a chapel was formerly appropriated to it in St. Mary Bonrne Church, now the "Week aisle." The Fanconers or Falconers held the manor in 1263 and after. The same was held by Nicholas Beyntun in 1422, and in 1466 it was held by John Beyntan, Robert Bayntun sold the manor in 1476, and in 1485 George Nevill had a grant of the same. It was then called Daundelese Wyke. It would appear that Sir Michael Lister had the reversion of the manor granted him after the death of Elizabeth Bayntun. The Oxenbridges lived at Week. Mrs. Barbara Oxenbridge appears in 1591 as occupying Week at the sane time, her son Sir Kobert lived at Hurstbonrne Priors. It appears from a document in the

1553,) by Sir Robert Oxenbridge, and continued in that family till 10 Car. I., when it was sold by the then Sir Robert Oxenbridge to Sir Henry Wallop, of Farley Wallop, ancestor of the present Earl of Portsmonth, whose seatHurstbonrne Park, extends over a large portion of the parish. Captain Symonds, a royalist officer, who was quartered with the King's troop of Life Guards at Longparish 19 Oct., 1644, shortly before the second battle of Newbary, writes in his Diary of the Royal Marches: "Mr. Robert Wallop lives at Husborne Prior, a faire old howse and large park with many ewe trees. Sir Henry Wallop, father to Robert, bought it of Sir Robert Oxenbridge."

Swampton. This tithing appears in Domesday as Suantune, in the Hundred of Clere. In 1476 it was held in comnon with Wyke Manor by Robert Baynton, and in 1485 it was granted, together with Wyke, to Sir George Nevill, and was included in the grant made to Sir John Gates in 1553.

Borne or St. Mary Bourne. The parish contains the six tithings of Bourne, Binley (including Wadwick or Warwick hamlet), Egbury, Week or Wyke, Stoke, and Swanipton. The benefice of St. Mary Bourne is consolidated with the vicarage of Hurtbonrne Priors. 


\section{EGBERry. *}

Christopher Goddwine for his hould there ij buh.

Richard Barnard for all the land he houldeth

William Newell for his hould there

William Brighte for his hould there

George Godden for his hould there -

Thomas Kidgell for his hould there -

Bartholomew Broadway for his houlde-

Simon Taylor for his houlde - - j buh.

1 qrter

iiij buh.

\section{Binleye. $†$}

Christopher Kiggell (Kidgell) for his hould there

William Geynes for his hould there

Thomas Poore for his hould there

Nicholas Philpott for his hould there -

John Angell for all the lande he holdeth

John Penton for his hould .

Jefferie Poore for his hould there -

Thomas Newell for his hould there -

Christopher Skinner for his hould there

ij buh.

ij buh.

j buh.

j buh.

j buh.

ij buh.

- Egberry or Egbury. Upon Egbury Hill is a remarkable British entrenchment known as Egbury Castle, of an irregalar pentaronal form, which many archrologists are inclined to regard as the site of the ancient Vindomis. On the left of the camp is the wooded hanging called Downham. Buckett's Down, a name which appears in this sarvey is in the tithing.

Dnnley is a hamlet in the tithing of Egbary. This formed part of the property purchased by the Oxenbridges of the representatives of Sir John Gates, and was formerly a house of the Knights Hospitallers of St. John of Jerasalem.

Between St. Mary Boorne and Egbary, an old drove is traversed, which has been a boundary since the time of the Sarons. It is also worthy of note that there is a portion of a paved way, sinilar to the cobbled roads of the Romans, between Dunley and Egbury; and another section may be seen on the line of the ancient pack-horse road running through Easton Wood, and on to Stoke.

t Binley is two miles on the N.E. of St. Mary Bonrne. In a Sabsidy Roll, 37 Hen. VIII., 1545, Binley is termed the "Parissche of Binley," but in 2nd and 3rd of Edward VI., it receives the title of tithing. In this roll some names appear the same as those at present living in the tithing, namely Purveyer or Purver and Harrys.

Probate Court at Winchester that Edward, Lord Beauchamp occupied " Week" previous to 1612. It was afterwards in the occupation of $P$ anl Alexander. The old manor honse of the Oxenbridges has undergone rejented alterations, but there are some remains in the present residence at Week, inclnding a hne stack of chimneys of Jacobean date. A field near the house which commands beantiful views of the surrounding country, is called the Court Garden, or "Court Hayes," which possibly has reference to the Hayes family, who it will be seen were residing in the tithing at the date of this sarvey. 


\section{WOODHEYE.*}

Edward Longman for the ffarm there -

Edward Goddard, Esqr., for the land he holdeth - - - - - viij buh.

William Rumboll for the parsonage there and other lands he houldeth -

John Whitear for his hould there.

George Knighte for his hould there -

Richard Bekensall for his hould there.

\section{Echenswell. $\dagger$}

Henry Wither for the ffarme there

Edward Wither for the parsonage there

John Winckworth, senr., for his hould there

John Winckworth, junr., for his hould there

francis Wall for his houlde there

\section{Ashmansworthe. $\ddagger$}

John Cole for the ffarme there -

John Bacheler for his hould there .

Nicholas Houldwaye for his hould there

Alice Houldwaye for her hould there -

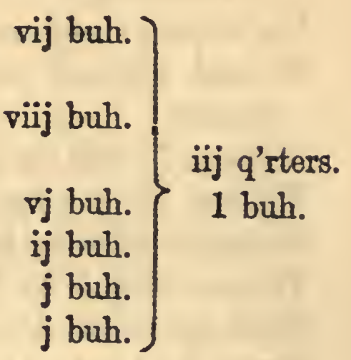

\section{HighCleRe aNd HawCLeRe. \|}

- Woodheye or East Woodhay. The manor of Woodhay (Widehaje) was given to the Church of Winchester by Athelgar or Algar, first abbot of the New Minster, Winchester, A.D. 964, and afterwards Archbishop of Canterbury. The Church of Woodhay is one of those enumerated as bestowed on the Hospital of St. Cross in De Blois charter of foundation.

+ The Eccleswille of Domesday, which belonged to the Priory of St. Swithin, Winchester, and is included in the list of the bishops' manors in the Taxatio Ecclesiastica.

$\ddagger$ Ashmansworthe. The manor was given by King Athelstan, (925-940), to the Priory of St. Swithin, Winchester. It was formerly a Peculiar of the Bishops of Winchester, and annexed to the Rectory of East Woodhay, but is now a separate ecclesiastical parish.

II Highclere and Hawvelere. The nane of High Clere is derived from its lying high above the neighbouring town of Kings Clere, the Clere of Domesday, as Burghclere is related to the Anglo-Saxon burh or burg an earthwork, such as the earthen fort which crowns the hill above the village. "Hawclere" a name long passed out of remembrance, was that part of the parish now known as "Highclere Street." Hawo; German gehavo is a place where trees have been hevon. Nearly the same as field, A. S. feld, a forest clearing, and as the greater part of this parish was formerly forest, its name, no doubt, represents a portion which was cleared and enclosed in early days. Highclere was anciently one of the residences of the Bishops of Winchester, who held it and large estates in the surrounding parishes, at the time of Edward the Confessor. The bailizcick of Highclere continned in possession of the 
Richard Kingsmill, Esqr. for the ffarmethere vj buh. Mr. Gunter for the parsonage and other lande

Robert Beckensall for his hould there John Sawyear for his hould there Philip Cumen for his hould there. Peter Waterman for his hould there . Morrice Cooper for his hould there Edward ffroome for his hould there - j buh.

j qrter. vij buh.

\section{Borrowcleare. *}

John Beckensall for the ffarme there - xiiij buh. the same John Beckensall for the p'sonage $x j$ buh. the same John Beckensall for his hould - $\quad j$ buh. William Cleeve for Wrightes hould there the same William for his other hould there William Yeeles for his hould there Simon Yeeles for his hould there John A'Lee for his hould there William ffolwell for his hould there John Herryett for his hould there - j buh.

ij buh.

j buh. $\mathrm{j}$ buh. j buh. $\mathrm{j}$ buh. j buh. iiij qrters. ij buh.

Baghurste. $\dagger$

William Drake for the p'sonage there - j buh.

Sum'a totall of wheat within the hundred of Evenger

- xxxij quarters.

- Borrowelere or Burghclere. The manor of Barghclere, together with those specified above, formed part of the original possessions of the Priory of St. Swithin, Winchester, as a member of the bailiwick of Highclere.

+ Baghurste or Bangharst. The Chorch of Bagharst was one of those added by De 13lois to his charter of foundation of St. Cross. The Dean and Chapter of Winchester are lords of the manor.

bishopric till the reign of Edward VI., when it was dismembered by Bishop Poynet, who, in 1552, transferred to the king the manors and freewarrens of Highclere and Burghclere, with the advowsons of the charches. In the sane year the King granted these manors to Sir William Fitz-William, one of the grentlemen of his bed-chamber. The heirs of Fitzwillian sold the estate to Sir Richard Kingsmill, knt., of Sydmonton, which included the inawors of East Woodhay, Ashmansworth, Ecchenswell, Burghclere, and Newtown, which form the remainder of the ancient bailiwick of Highclere. The name of Comyns written Cnmen or Cummen in the Survey, is one of the oldest in the parish. They lived at "Haiwclere," and their lands descended to the Baymans, from whom it was bought by Lord Carnarvon about three years ago. There are a great many Comyns still left, some at Burghclere, and others at Crux-Easton. 
1575 EUENGER for the payment of xvj lambes.

Husborne.

Anthony Heath for his hould there Morrice Holland for his hould there William Goulding for his hould there John Locke for his hould there - . Elizabeth Nowell for her hould there -

Richard Blaunchard for his bould there

John Brooker for his hould there George Penton for his hould there Thomas Adnam for his hould there Robert Hedger for his hould there John Billett for his hould there John Waterman for his hould there

Boorse.

Bartholomew Smith for his hould there John Smith for his hould there - . Hugh Ildwerwill for his hould there William Issarne for his hould there

STOKE.

Bawdwine Leach for his hould there Thomas Dowce for his hould there William Woodward for his hould there George Bachelor, for his hould there Joane Hawkines for her hould there Robert Pococke for his hould there

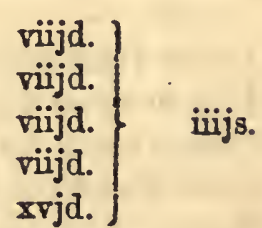

viijd. viijd. viijd. viijd. viijd. iijd. ob. qr. iiijd. qr.

iiijs.

WeEK and Binlye.

Thomas Horne for his hould there - viijd. ob. William Kidgill for his hould there - viijd. ob. George Dyer for his hould there Richard Downe for his hould there

- xvd. ob.

iiijs.

BorrowCleare.

Richard Wheeler for his hould there - viijd. Philip A'Lee for his hould there - - v viijd. John Clarke for his hould there - - viijd. John Steptoe for his hould there - - v viijd. Elinor Arundell for her hould there - viijd. John Peirce for his hould there - - viijd. 
Agnes Peirce for her hould there

John Acwell for his hould there -

- ixd. ob.

John Nutkine for his hould there

William Withers for his hould there

Richard Wheeler for his hould there

Agnes Cooper for her hould there

- ixd. ob.

- ixd. ob.

- ixd. ob.

iiijs.

John Wheeler, junior, for his hould there xiiij ob.

Thomas A'Lee for his hould there - xixd.

iiijs.

John Wheeler, senior, for his hould there

John Arundell for his hould thero

John White for his hould there -

Richard Crooke for his hould there

John Garraway for his hould there

Joane Deacon for her hould there

Richard Brooke for his hould there

Potters hould there

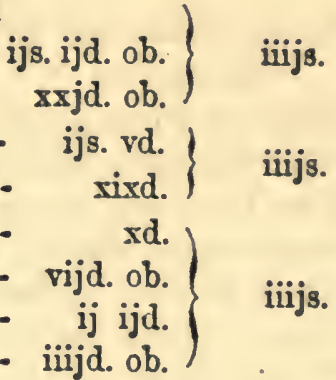

Newtowne. *

Walter Benham for his hould and lands there iijs.

iiijs.

Ashmansworth.

John Thurman for his hould there

Thomas Holdway for his hould there -

John Cole for his hould there - .

Joane Cole for her hould there - .

John Holdway for his hould there

Amye Steuins for her hould there -

Thomas Hellyer for his hould there -

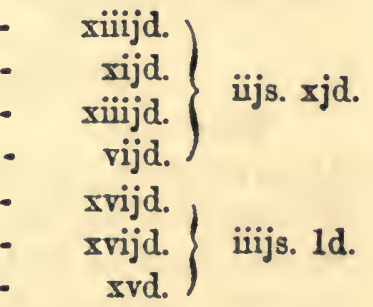

WHITCHURCH.

William Queene for his hould there - viijd. ob.

John Howse for his hould there - - viijd. ob.

Thomas Reynoldes for his hould there - viijd.

Richard Perrye for his hould there - viijd.

John Spencer for his hould there - - viijd.

iiijs.

Thomas Siluer for his hould there - iijd. ob.

Thomas Longe, senr., for his hould there iijd. ob.

- Newtowne. On the borders of Berks. In the Texatio Eoclesiastica, Newtown is assigned to the Hundred of Clere, or Kingsclere ; and belonged to the ancient foundation of St. Swithin's Priory, Winchester, as a member of the bailiwick of Highclere. 
Richard Poynter * for his hould there Thomas Webbe + for his hould there -

Robert Benham for his hould there -

Henry Benham for his hould there -

John Lambden for his hould in Henlye

Robert Smithe for his houlde there -

John Poynter for his houlde there

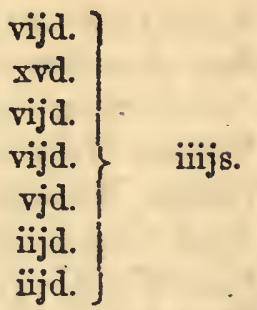

- iij li. iiijs.

Sum: totall for the lambes

EURNakr hundred for the payment of xj Capone.

Woodheye.

Elizabeth Barebon for her hould there -

John Young for his hould there - - - i i

John Houldway for his hould there - - i

Bartholomew Rumboll for his hould there - i

Agnes Androes for her hould there - - i

Drewe Rumboll for her hould there - - i $\quad$ xj Capons.

Richard Herne for his hould there - - i

Simon Parker for his hould there - - i

Richard Houldway for his hould there- - i

Thomas Walter for his hould there - - i

Elizabeth Hellyer for her hould there - - i

ffor the payment of xvij hennes.

\section{WOODHEYE.}

Agnes Osgood for her hould there - - i)

Elizabeth Pearman for her hould there - i

Thomas Robinson for his hould there - - i

John Durman for his houlde - - - i

Margery Harris for her houlde - - - i

William Ballard for his houlde - - - i

John Peaze for his houlde - - - - i

John Houldway for his houlde - - - i

Richard Wheeler for his houlde - - - i

John Barbon for his houlde - - - i

John Alexander for his houlde - . - i

Thomas Manfielde fo his houlde - - i

Ellice ffeilde for his houlde - - - i

- The Poynters are still a well-known Hampshire family.

+ The name of Webb is of very ancient standing in Whitchurch and neighbonrhood.

xvij henes. 
Richard Hinde for his houlde - - - i

John Angell for his houlde - $\quad$ - $\quad$ i

HrGHCLERE.

John Honywell for his houlde - - - i

William Younge for his houlde - - - i

ffor the payment of $x j$ : geese.

\section{BAGHURST.}

Hugh ffreeborn for his houlde there - $\quad$ i

Thomas Harmsworthe for his houlde - - i

William Dicker for his houlde - - - i

Richard Wither for his houlde - - - i

Robert Greene for his houlde there - . i

William Bye and John Marsh for ther two holdes

- $i$

Spencer for his houlde - $\quad$ - i i xj geese.

Nicholas Potter for his houlde - - - i

Ingram Baghursto for his houlde - - i

William Deane for his houlde he holdeth of the Deanary * - - - - - i

the same William for the houlde he holdeth

of Mr. George Ludlowe t - - - i

ffor the payment of $x x x^{t i}$. pulletts.

\section{Ashmansworthe and Highclere.}

Thomas Penton for his hould there - - ij

Walter Houldway for his hould - - - j

John Walter for his houldo there - - j

$\left.\begin{array}{llll}\text { Peeter Longe for his houlde there } & - & - & \mathrm{j} \\ \text { John Greene for his houlde there } & - & - & \mathrm{j}\end{array}\right\}$ vij pulletts.

William ffrome + for his houlde there - - j j

- The Deanerg. Land held of the Dean and Cbapter of Winchester, lorda of the Manor.

+ George Ludlow. Son of William Ladlow, of Tadley Place, and Hill Deverill, high sheriff of Wilts, 1567. In his will proved in 1580 he describes himself of West or Monks' Sherborne. He married Edith, third danghter of Lord Windsor, of Stanwell.

\$ William frome. The name of Frome still sarvives at Ashnuansworth. 
Ecchenswell.

Richard Bever for his houlde there Ingram ffrancklin for his houlde there Thomas ffrancklin for his houlde there William Reynolde for his houlde there John White for his houlde there John Reynolde for his houlde there Joane Younge for her houlde Richard Southe for his houlde there Pawle Winckorthe for his houlde there John Legatt for his hould there William Prixmall for his hould there John ffosberrye for his hould there Walter Awforde for his hould there Nicholas Whetlande for his hould there Walter Spencer for his houlde there Edmonde Winckorthe for his houlde there William White for his hould there - John Rumble for his hould there - Allice Younge for her hould there - Peeter Rowlande for his hould there - John Benam for his hould there John Younge, of Webb-haye for his hould there

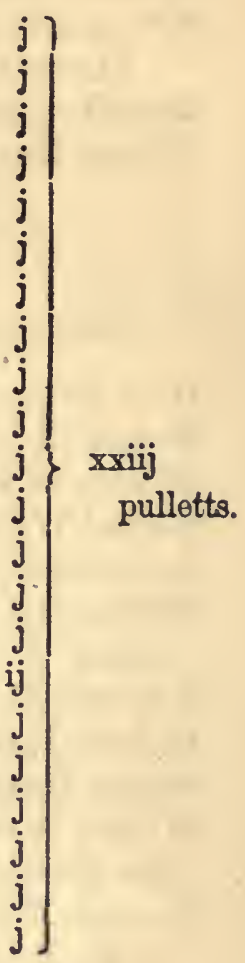

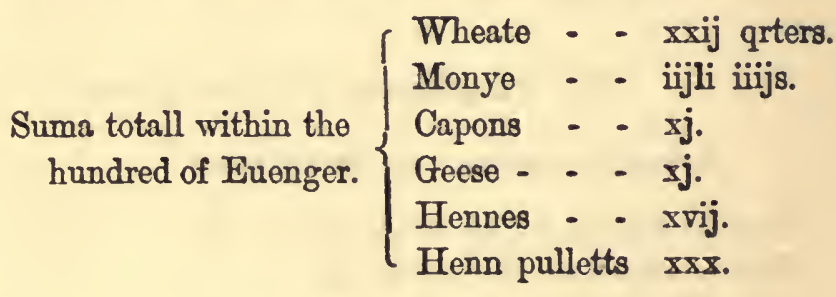


The hundred of

CHutLye. 1575 ffor the payment of xij qrters whente. Sherborye. *

John Haskar $\dagger$ for his ffarme there - vj buh. John Hasker for his tythe there Richard Pincke for his ffarme there the same Richard for his tythe there The ground called the priorye in the handes of James Trew

Joane Hawkine for her hould there $\left.\begin{array}{rr}- \text { ij buh. di. } \\ - & \text { vj buh. } \\ - & \text { j buh. } \\ \text { - ij buh. di. } \\ -\quad \text { j buh. }\end{array}\right\}$ ij qrters. WoOrTiNge. $\ddagger$

John Stanbrooke for his hould there the same John Stanbrooke for the parsonage

Thomas Trewe for the ffarme there

iij buh. $?$

ii buh. $\{$ j qrter. iij buh.

\section{LAURENCE WotTon. §}

John Wither for his hould there

Agnis Small for her hould there -

Thomas Ailiffe for his hould there

William Ailiffe for his ffarme there

- j buh. di. ]

- $\quad$ ij buh.

- iiij buh. - iij buh.

Richard ffreemantlell for his hould there $\mathrm{j}$ buh. di.

Thomas A. Lee for his hould there j buh.

Richard Wither for his ffarme and tythe xviij buh. the Vicar of Wotton - - _ - j buh.

iij qrters. vij buh.

* Monks' Sherborne, so-called from the Benedictine Priory founded here by Henry de Port, one of the Barons of the Exchequer, in the reign of Henry I.

$t$ John Hasker. The Haskers were an ancient yeoman family in Hampshire. John Hasker, gent., is described as of Bramley, in 1731, and his son, also John, of the same place, where they possessed considerable property. For several generations the family occupied a position as prominent citizens of

Newbary. John Hasker was Mayor of the Borough in 1787 and 1799, and his son, John Hasker, J.P., in 1819. The latter was lay-rector of Frosheld, Wilts.

$\ddagger$ Woortinge or Worting, a village, $2 \mathrm{~m}$. W. of Basingstoke.

\& Lawrence Wotton. Now Wootton St. Lawrence, a village, $4 \mathrm{~m}$., W.N.W. of Basingstoke. There are several monaments in the charch to the ancient Hampshire family of Wither, who have held property in the parish for over 500 years.

II The name of Freemantle is one of the oldest in this part of Hampshire, and there is little doubt but that the ancestors of those who bear this name in this part of England derived it from the royal park or chase of Freemantle, near Kingsclere-a favourite hunting seat of the Norman and Plantagenet Kings. The Freemantles have always been known as an independent and manly race of yeomen, but of late years bad times has compelled the old race of English farmers to embark in new enterprises and to settle away from the homes of their ancestors. 


\section{Hanington:*}

Margery Dicker for her hould there Thomas Wareham + for his hould there Richard Drewett for his hould there Thomas Drewett for his ffarme there $\ddagger$ the same Thomas for the parsonage there William Soper§ for his ffarme groundes there

\section{Church Oaklye. $\|$}

Sr. William Kingsmill, knight, If for malsanger and for the Deanes land the Lady Wareham ** for her ffarme there William Wigg $+t$ for his ffarme there William Ayliffe for his ffarme there Richard Winckworth for his ffarme there Humfrie Ayliffe for his hould there the Lady Wareham for the parsonage -

$$
\left.\begin{array}{l}
\text { Suma totall of wheate } \\
\text { in Chutlye Hundred. }
\end{array}\right\} \begin{aligned}
& x i j \\
& x i j \\
& \text { qrtere. }
\end{aligned}
$$

*. Hanington or Hannington. A village on the sonth side of the North Downs, $2 \frac{1}{2}$ n. S. by E. of Kingsclere. Part of the village is in the tithing of Hannington Lances, in Kingsclere parish. The Dean and Chapter. of Win. chester are Lords of the Manor.

+ Thomas Wareham. See note to Church Oakley.

$\ddagger$ Thomas Drewett. The name of Drewett or Dreweatt, from the Nornan Druett or Drouet, occurs in England in the form of Druett about 1272. A well-known family of this name was long settled in the parish of Welford, Berks, and the present head of that family is the well-known Mr. Thonas Dreweatt, of Newbury.

$\$$ The family of Soper has always been resident here from Elizabethan days, and earlier, to the present time.

II Church Oakley. A small village, $4 \frac{1}{2} \mathrm{~m}$. W. by S. of Basingstoke.

I Sir Williain Kingsmill, Knt., of Sydmonton.

** Lady Warham. Malshanger in the parish of Church Oakley was the birthplace of William Warham, Lord Chancellor of Englend from 1504 to 1515, and Archbishop of Canterbnry from 1504 till his death in 1532. The Warhams appear to have been a numerons family in this part of North Hants at the period before us, and we find them holding land at Church Oakley, Monks' Sherborne, Lawrence Wotton, Hanington, Kingselere, North Oakley, and North Waltham. From the pedigree entered in the Hants Visitation, it appears that the Archbishop, who was the son of William Warham, of Malshanger, by Ann his wife, eldest daughter of Thomas Hednor, of Denton, co. Sussex, had three brothers, Nicholas of Malshanger, Hugh of the same place, and Robert. Nicholas had two sons, Sir George Warham of Malshanger, and William Warham, Archdeacon of Canterbury. Hagh had two sons, Richard, a priest, and Sir William, knt., of Malshanger, whose danghter and heiress Anne, married Richard Puttenhan, of Sherfield in this connty, and probably carried the estate of Malshanger into that family.

t+ The Wigg family is still a well-known one in the neighbourhood of Basingstoke. A Willian Wigg was Mayor of Winchester in 1399-1400. 
The

Chutry, 1575. ffor the payment of ix lambes.

Sherborne.

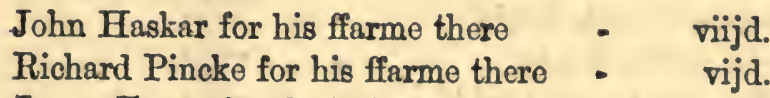

James Trewe for the Priorye - - vijd.

Thomas Russell for his hould there - ijd.

Richard Hawkene for his hould there - $\quad$ iijd.

William Haskar for his hould there - ijd.

John South for his hould there - - ixd.

Agnes Hawkine for her hould there - iijd.

the same Agnes for Bulcroftes - - iijd.

the same Agnes for other landes - - - jd.

Clemente Touye for his hould there - xiijd. ob. vijs. ixd.

John Holmes for his ground there - ijd.

Edmunde Pincke * for his ground there ijd.

William Harnewood for hould there - ijd.

Joane Sherwood for her ground there - ijd.

Katherine Harris for her ground - ijd.

Alexander ffroglye for his ground - ijd.

John Woode for his hould there - - v vjd.

John Dawman for his hould there - ixd.

Thomas Cooper for his hould there - ijd.

Richard Riue for Stiwardes - - ijd. ob.

Woortivge.

Widow Whitehorne for her hould there

Anthony Snowe for his hould there

John Gardner for his hould there

Thomas Starke for his hould there -

the widow Lardner for her hould there

Laurexce Wotton.

Thomas Ayliffe for his land there - $\quad$ xijd.

William Ayliffe for his ffarmo there - vjd.

Richard Wither for his ffarme there - xijd.

John Browne for his hould there - xiijd.

Richard Small for his hould - - $\quad x d$.

- Kempshott near Basingstoke, was long the residence of the Pink, or, as here written, "Pincke" family, one of whom Robert Pink, was born here in the reign of Elizabeth, and became eminent as a philosopher and divine. He was Warden of New College, where he died in 1647. The last of the family sold the estate about 1770 , and it has since passed to various owners. 
Robert Buttler for his hould there - $\quad x j d$. Richard Browne for his hould there - xvijd. John Prymer for his hould - - - riijd. William Randall for his hould - - viijd. Robert Hacke for his hould - - viijd. Humfrye Poynder for his hould - - v viijd. Thomas Rabnett for his hould - - $\quad$ xijd. Maude Wareham for her hould - xvjd. Hugh Spencer for her hould - - xiijd. Richard Hall for his hould - - e svjd. John Mortimer for his hould - - xvjd. Widdow Parker for her hould there - ixd. John Wissam for his hould - - vjd. Allice Simpson for her houlde - - ixd. John Soper for his houlde there - $\quad$ xwd.

Suma: xviijs. ixd.

\section{Hanington.}

$\left.\begin{array}{lllr}\text { Thomas Drewett ffor his ffarme } & - & - & \text { vijd. } \\ \text { George Upton for his hould } & - & - & \text { xiijd. }\end{array}\right\} \quad$ sxjd.

Church Oaklye.

William Wigge for his ffarme there - xijd. Dauye Smith for his hould there - $\quad$ xjd. William Ailiffe, junr., for his hould - xviijd. Guye Losse for his hould there - - vjd.

Suma for ix lambes out of
the hundred of Chutlye.

ffor the payment of fire geese.

SherborNe.

Thomas Wareham for his hould - - j. the ground called Rawlins - - - j.

Laurearce Wotton.

Margaret Carter for her hould there

Hanington.

John Hinwood for his hould there Nicholas Wither for his hould there

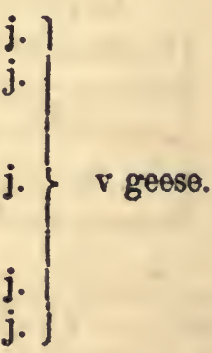

* The exact amount is 35s. 10d. 
ffor the payment of five Capons.

Sherborne.

ffrancis Wickens for his hould there -

Hanington.

Richard Harris for his hould there

Elioner Wareham for her hould there -

John Apleton ffor his hould there -

Jane Hall for her hould there

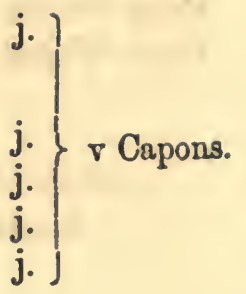

ffor the payment of eight hennes.

Sherborne.

Richard Pickmonde for his hould there

Thomas Russell for his hould there -

Richard Hawkine for his hould there -

Laurence Wootton.

Richard Hacke for his hould there -

Mawde Wareham for her hould there -

John Soper for his hould there - .

Hanington.

John Hinwood for his hould there - j.

Nicholas Wither for his hould there - j.

ffor the payment of xiiij. pullets.

\section{ShERBorNe.}

Thomas Voaxe for his hould there

James South for his hould there -

Thomas Voaxe for his hould there

Anthony Bushell for his hould there -

William Hasker for his hould there

Woortinge.

Robert Baylie for his hould there Peter Baylie for his hould there Widow Alsopp for her hould there

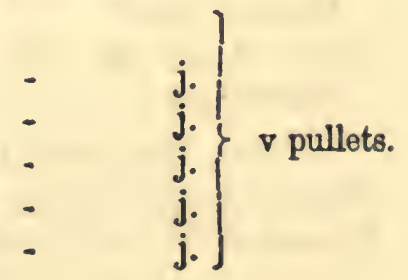

Laurexce Wootton.

Ideth Burnell for her hould there

John Knighto for his hould there

Joane White for her hould there

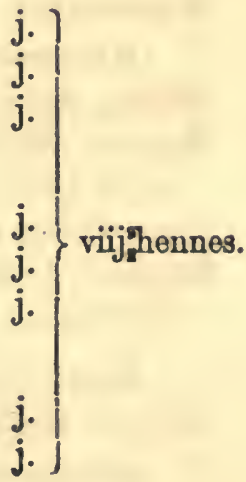

$$
\text { pullets j. } \begin{aligned}
& \text { j. } \\
& \text { j. }
\end{aligned} \text { iij pulletts. }
$$

$\begin{array}{ll}- & \text { j. } \\ - & \text { j. } \\ - & \text { j. }\end{array}$ iij pulletts. 
Hanington.

Michell Gedge for his hould there Philip Primer for his hould there Joane Wither for her hould there

Suma totall within the hundred of Chutlye.

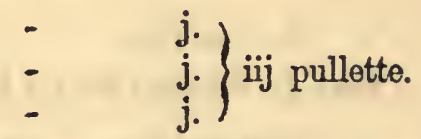

Wheato xij quarters. Money for lambes xxxvjs. Geese - $\nabla$. Capons - $\nabla$. Hennes - viij. Pulletts - xiiij.

The hundred of

Kingsclere. I 1575 ffor the payment of xp. qrters. wheate.

Earlestone.*

William ffolwell for the farme there

Margaret Withers for the hould there called Babbs

James Hunte for Gudgins - - -

Edmund Cooke for his land called Rockhouse

Edmonstrop Launcewell. $\dagger$

Nicholas Wigmore for his hould -

Edmonstrop Beenam. $\ddagger$

Vahan Beecher for the ffarme called Beenam Courte - - - -

James Hunte for the ffarme called Appshanger - - - - - j buh.

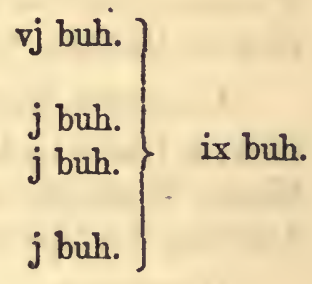

Clere Woodcott. $\S$

Nicholas Knighte for the ffarme there - ij buh. Richard Webb for Knowle hill ffarme - ij buh. di. iiij buh, di.

* Earlstone. A tithing in the parish of Barghclere. The present farmhouse was formerly a residence of importance, and in the last century was occupied by 1 dmiral Ambrose, lord of the manor. All the former extensive open fields have been swept away by the rathless process of an Enclosure Act. + Edmonstrop Lanncewell. Now called Edmonstrip Lances-a tithing of Kingsclere, $1 \frac{1}{2} \mathrm{~m}$. $\mathbf{N}$. of that place.

$\ddagger$ Edmonstrop Beenam. Now called Edmondstrip Beenham. A tithing $2 \frac{1}{2} \mathrm{~m}$. N. of Kingsclere. A modern mansion now stands on the site of the ancient Beenam Conrte. Edmonstrop, or Edmundsthrop Beenham was the birthplace of Kichard Mayhow (Mayo), elected Chancellor of the University of Oxford in 1503, and in the year after Bishop of Hereford.

$\S$ Clere Woodcott. The tithing of Clere Woodcott inclndes Knowle Hill Farm, Harridans and Hall Farms, and Ram Alley Farm. 
Haniton Launcelewell. *

Henry Kingsmill, Esq., for the ffarme

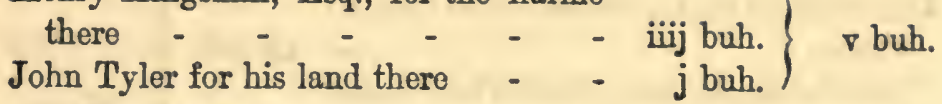

Ewhurste. $†$

Richard Aylife for his lande there - vij buh.

Woolverton. +

Thomas Gardner for the ffarme there - vij buh.

Robert Heron for the parsonage there - ij buh.

John Butler for his hould there - - j buh., di.

Hugh Keene for his hould there

Lawrence Style for his hould there - $\mathrm{j}$ buh.

SANDFORD. §

$\left.\begin{array}{l}\text { Elizabeth Hunte for the ffarme there - } \text { iij buh. } \\ \text { John Mason for his hould there - } \quad \text { j buh. }\end{array}\right\}$ iij buh.

Srdmonntaine. \|

The ground called Cambers in the occupation of Sir William Kingsmill, knight

j buh.

\section{FFROBERRYE. ?}

James Hunte for the ffarme of ffroberrye

Richard Knight, gent. for his hould there

George Hunte for his landes there -

Henry Smith, gent., for his land and

the same Henry Smith for the Chapell landes** - - - - - j buh.

$\left.\begin{array}{l}\text { iij buh. } \\ \text { ij buh. } \\ \text { ij buh. } \\ \text { j buh. } \\ \text { j buh. }\end{array}\right\}$ ix buh.

* Haniton Ianncelewell. Now called Hannington Lances-a tiching, $2 \mathrm{~m}$. S.E. of Kingsclere.

+ Ewharste. A small parish, 3 m. E. by S. of Kingsclere.

Woolv erton or Wolverton, $1 \frac{1}{2}$ to $2 \frac{1}{2} \mathrm{~m}$. E. of Kingselere.

\$ Sandford. One of the eleven tithings of Kingsclere, $1 \mathrm{~m}$. E. of that place.

II Sydmonntaine now Sydmonton. The Sidemaneston of Domesday, Sydmonton Court has been the seat of the Kingsmill family since the dissolution of the monasteries, when the extate was granted by Henry VIII. to John Kingsmill and his wife Constance, dau. of John Goring, of Burton, co. Sussex, Esq. About 764 acres of land in the parish belonged to Romsey $\mathrm{Abbey}$, and paid one acre of wheat and one of barley in lieu of rectorial tithe, and $\$ 40$ annually in lien of vicarial tithe.

If froberrye, now Frobury, a tithing, $\frac{1}{2}-\mathrm{m} . \mathrm{N} . \mathrm{W}$. of Kingsclere.

** The remains of the old inanor-hoase is now occupied by the farmer of the lands. On the south side of the honse are the ruins of an ancient chapel, to which it will be seen certain "landes" wero attached. The house at this time was in the occnpation of Henry Sinith, gent., whose descendants for generations were yeomen in the neighbourhood. In 1641, Robert Towers is described as of Frobnry, gent., and received King Charles I., at his hoase here 21 Oct., 1644, a few days before the second battle of Newbury, the king being then on his narch towards that place. 


\section{The LoRdshipp. *}

James Hunte for the ffarme called Canon Courte +

Peeter ffalckoner, gent., for his land called

Lynners and Newlandes -

John Hinwood for his hould and lyuinge $\ddagger$

William Spencer for his hould there

Nicholas Knight for the Swann lande -

\section{OAKELYE. $\S$}

William Hellyer for the ffarme there - viij buh. John Knight for his ffarme there - iij buh. the same John Knight for Tydgrove - j buh. William Smith for his ffarme there - j buh. Thomas Warham for Boldsoms - - iij buh. Richard Ailife for Pitt grounde - William Smith for his liuing there, parcell of his farme John Butler for pitt grounde - - j buh.

iij qre. iij buh.

\section{Kingsclere Parsonage.}

Stephen Knight for the parsonage whereof $\mathrm{j}$ bus. to be paid by Elizabeth Atfield during the time of her tythe in the Woodland -

\section{$\left.\begin{array}{c}\text { Suma of wheat within the } \\ \text { hundred of Kingsclere. }\end{array}\right\} x \nabla$ quarters.}

* The Lordship. A tithing of Kingsclere now called Lordship Town Part, Kingsclere, the Cleve of Domesday was given to the Priory of St. Swithin, Winchester, and is included in the list of bishops' manors in the Taxatio Ecclesiastica.

+ Canon Courte, about $2 \mathrm{~m}, \mathrm{~S} . \mathrm{W}$. of Kingsclere. Upon the site of the ancient Canon Conrte stood Canham or Cannon's Lodge, in a hollow of the chalk downs. It was boilt in the 17th century by Charles, Duke of Bolton, of materials bronght from the ruins of Basing House after the famons siege by Cromwell, and was for some time occupied as a hunting box by the Earl of Mexborough, and afterwards by the Dake of Cumberland. It was pulled down in 1805, when the heath was converted into a farm. It now forms part of the famous training quarters of Mr. John Porter.

† Lyuinge i.e. living-a farm.

$\$$ Oakelye-North Oakley, a tithing of Kingsclere, $3 \mathrm{~m}$. S. by E. of that place. 
ffor the payment of ix lambes.

Earleston.

ijd. Edward Withers for his hould there ijd. George Masonne for his hould there ob. William Withers for his hould there

\section{Edmonstrop Launcewell.}

id. ob. Nicholas Knight for houldip hill id. Walter Knight for his hould there -

\section{Edmonstrop Berian.}

\section{ob. Thomas Wayte for Westlandes}

id. ob. Walter Mace for his hould there ob. Ingram Bachelor for his land there jid. ob. Henry Withers for Strattons ob. John Lawrence for Scroches lande ob. John Chamberlain for the land called Pitchorne

\section{Clere-Woodcott.}

ob. Jeames Hunte for the land called Gillmans

ob. Richard Webbe for the ground called pastures

\section{Ewhurste.}

ijd. Richard Ailife for his land there called ffinley -

Wooluerton.

id. John Humber for his hould there -

id. Margarett Buttler for her ground there

ob. William Siluester for his hould there

\section{SANDFORDE.}

ob. Thomas Early for his hould there -

ob. Thomas Hogge for his hould there

ob. Edward A. Berrye * for his hould there

ob. William Osmonde for his hould there

id. Amye ffroude for her hould there

$$
\left.\begin{array}{r}
\text { vjd. } \\
\text { vjd. } \\
\text { iiijd. }
\end{array}\right\} \quad \text { svjd. }
$$

viijd.
vjd. $\quad$ xiijd.

$\left.\begin{array}{r}\text { iiijd. } \\ \text { vid. } \\ \text { iiijd. } \\ \text { iiijd. } \\ \text { iiijd. } \\ \text { iiijd. }\end{array}\right\}$ ijs. ijd.

$\left.\begin{array}{l}\text { iiijd. } \\ \text { iijdd. }\end{array}\right\}$ viijd.

xijd.

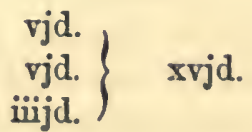<smiles>[Si][Si]C1CCCCC1</smiles>

- Edward A Berry. This, like many other aurnames to be found in these pages, is derived from residence. Edward A Berry-Edward at the Berry, similarly we have John Attewell-John at the Well, John att field-John at the field, Thomas a Lee-Thomas at the Lee, which gradually passed into Aberry, Attwell, Attfield, Atley and Allee as abbreviations. 
Sydmontaine and Lychfielde. *

ijs. Sr. William Kingsmill, knight, for the same ijd. John Harding for his hould there ijd. Little John Mason $†$ for his hould there ijd. Thomas Mason, of Aynolls for his hould there

xs. $\left.\begin{array}{l}\text { iiijd. } \\ \text { iijd. } \\ \text { iijd. }\end{array}\right\}$ xijd. FFROBERRYE.

ob. John Camber for his hould there ob. the lande of William Deane - .

iiijd. iiijd. viijd.

LORDSHIPP.

ijd. John Attfield for his land there ob. Elizabeth Attfield for her lande ijd. ob. John Bye, gent., for the land called foorth fills - - - ob. Nicholas Wigmore for his hould ob. Nicholas Wigmore, for Redeons lande ijd. Robert Bacheler for his hould there iiijd. Thomas Hawkines for his hould there

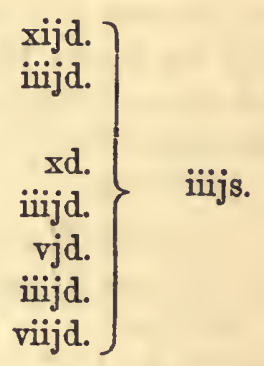

LORDSHIPP.

ijd. John Hide for Tuckers ob. Ingram Bachelor for his ground there ijd. Peter Knight for the land called

Starkers

iid. Thomas Bacheler for his hould there id. ob. Nicholas Frowde for his houlde there id. ob. Edward A Berrye for Rydinges Robert Mason for his lande there

Parsonage.

iiijd. William Hunte for his houlde there xjd.

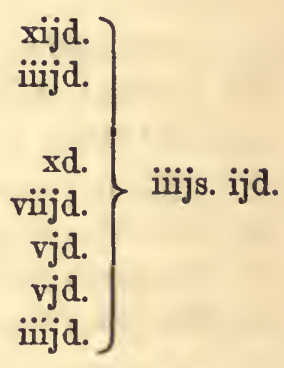

Suma for ix lambes.

* Lychfielde. A small village, $4 \mathrm{~m}$. N. of Whitchurch. The parish principally consists of one large farm belonging to the Kingsmills, of Sydmonton.

$\dagger$ Little John Mason. Here we have an instance of the origin of a sarname from personal characteristics, to distinguish him from others of the same family living in the same place. 
Kingsclere Hundred.

ffor the payment of vij geese.

Edmonstrop LaunceleuelL.

Walter Spencer one goose - - - $\quad$ i.

SANDFORD.

James fforde for his hould there - - $\quad$ i

Robert Wareham for his hould there - i.

LORDSHIPP.

John Parr for his hould there - -

John Stacie for his hould there. - -

Stephen Knight for Stantons - -

Piatstowe.

John Bacheler for his hould there

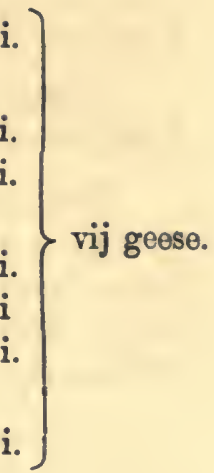

ffor the payment of $x j$ hennes.

Edmonstrop Beenam.

Margaret Buttler for her hould there -

Nicholas Millett for land called Pitchorne

Sidmonvtaine.

John Millett for his hould there - - i.

John Knowle for his hould there - -

Alice Nutt for her hould there - - i.

Thomas Smith for his hould there -

Thomas Mason, of Colletts, for his hould

Edmond Mason for his hould

Henry Weyer for his hould there -

Walter Salter for his hould there -

LORDSHIPP.

Walter Diker for his hould there

ffor payment of vij Capons.

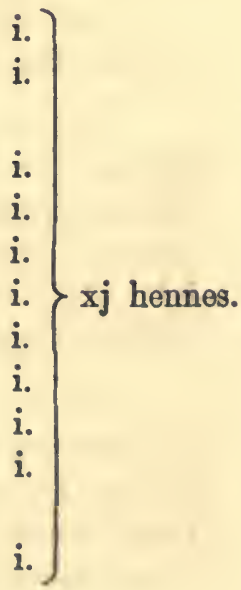

\section{SANDFORDE.}

Thomas Dyer for his hould there

LORDSHIPP.

Simon Holdip for his ground there -

William Wyett for his hould there -

Thomas Maye for his hould there -

John Wayte for his hould there -

Thomas Wayte for his hould there -

the land called Stony Hall

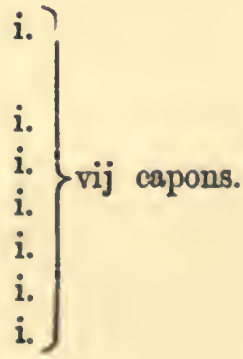


44 A ROYal PURVEYANCE IN THE ELIZABETHAN AGE.

ffor the payment of xix pulletts.

Edmonstrop Launcewell.

John Reynold for his hould there

John Loue Locke for his hould -

Edmonstrop beanam.

John Bacheler for his hould there - i.

WoLUERTON.

Alexander Smith for his hould there -

Robert Gedge for his hould there -

Thomas Maye for his hould there

William Spencer for his hould there

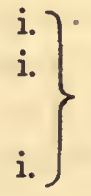

SANDFORD.

Nicholas fficas for his hould there

John Appleton for his hould there

FFROBERRY.

William Spackman for his hould there

$\left.\begin{array}{l}\text { i. } \\ \text { i. } \\ \text { i. }\end{array}\right\}$

LORDSHIPP.

Thomas Spencer for Attfeildes land -

William Goulding for his hould

Thomas Edwardes for his hould there -

John Strike for his hould there

William Merryett for his hould there -

The Parsonage.

Tristram Coxhead for gale mill

Thomas Pettye for his hould there

John Chamberlen for his hould there -

Peter Knight for his hould there $\quad-\quad$ i.

$\left.\begin{array}{l}\text { i. } \\ \text { i. }\end{array}\right\}$

i.)

i.

i.

i.

i.

Suma, xix pulletts.

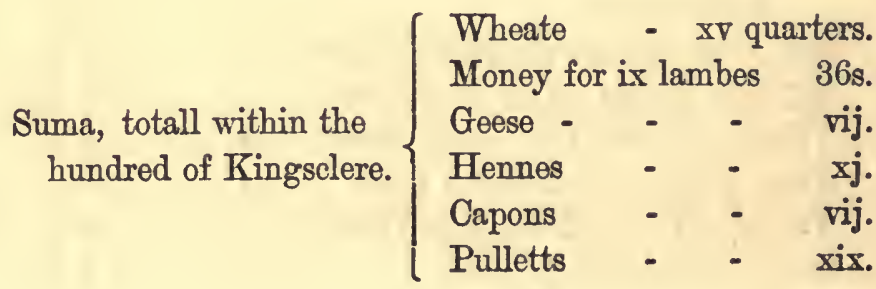


The hundred of

PAstroe, 1575. $\}$ ffor the payment of $\mathrm{xv} \mathrm{q}^{\text {rters. wheate. }}$

Crooxeaston.*

William Temple for his ij houldes - ij buh.

the parsonage there in the occupacon of

the said William Temple - - j buh.

$\left.\begin{array}{ll}\text { William Temple for the ffarme there - } & \mathrm{x} \text { buh. } \\ \text { Thomas Parker for his hould there } & \mathrm{j} \text { buh. }\end{array}\right\}$ xiiij bus.

FFACCOMBE. $\dagger$

Mr. Reade for the ffarme there - - iiij buh.

Thomas Bulpitt for his hould there - iiij huh.

Robert Wadlowe for his hould there - ij buh. di.

Thomas Hellyer for his hould there - i buh.

John Bunney for his hould there - i buh. ij qrs.

Agnis Hellyer for her hould there - i buh. iiij bus.

William Lake for his hould there - i buh.

Rowland Liuelocke for his hould there i buh.

Valentine Bulpitt for his hould there - i buh.

John Goodall for his hould there - i buh.

Lxychenholte. $\ddagger$

William Holte for his ffarme there - iiij buh.

Richard Graye for his hould there . - i buh.

Elizabeth Pollhamptine for her hould - i buh. $\}$ i quarter.

Robert Luneden for his hould there - i buh.

the parsonage there - - - - i buh.

Conholte. $\S$

William Hellyer for the ffarme there - v buh.

$\left.\begin{array}{lll}\text { William ffar for his hould there - } & - & \text { i buh. } \\ \text { Thomas Hellyer for his hould there } & - & \text { i buh. }\end{array}\right\}$ vij buh.

- Crooxeaston. Now Crax-Easton, a village on the sonthern side of the North Downs. William the Conqueror gave the manor to Croch, the huntsman, from whom it is sapposed to have had the name Croch or Crux Easton.

+ Faccombe, a village in the Kingsclere Division of North Hants, Netherton, where the old church stood, is abont a mile, W. of Faccombe. Wansdyke or Wodensdyke snpposed to have been a boundary daring the Saxon Heptarchy passes through the parish into Berkshire.

I Iynchenlolte, now Linkenholt, the Linchehou at Domesday Sarvey, when it belonged to St. Peter's Chorch at Gloncester, is a small village on an eminence, near the junction of the three counties of Hants, Wilts, and Berks. The manor of Linkenholt is now the property of H. C. Knowles, Esq.

$\$$ Conholte. Lower Conholt in Hurstbourne Tarrant parish, near the borders of Wiltshire. 


\section{Woodcotr. *}

Sir William Kingsmill for the ffarme William Still for his hould there $\left.\begin{array}{rrr}\text { Thomas Taylor for his hould there } & - & \text { i buh. } \\ \text { Edmond Winckworth for his hould } & - & \text { i buh. }\end{array}\right\}$ i quarter.

FFARNEHAM, DEANE. $\dagger$

Thomas Hellyer for the ffarme there - vj. buh. Thomas Rogers for that he houldeth there iij buh. Thomas Liuelocke for his hould there - i buh. di. Thomas Woolridge for his hould there i buh. di. John Castlegate for his hould there - i buh. Richard Hunte for his hould there - i buh. Robert Anker for his hould there - i buh. John Liuelock for his hould there - i buh. John Poore for his poore hould there - $\mathrm{i}$ buh. di. Nicholas Canon for his hould there - i buh. di. John Nalder for his hould there - i buh.

UpP HUsBorne. $\ddagger$

John Purchell for his hould there John Whitear for his hould there John Bunney for his hould there

- i buh. ? - i buh. di. - i buh. di. Christopher Rumboll for his hould there iij buh. Robert Talmage for his hould there - i buh. Robert Longman for his hould there - i buh. William Walleys for his hould there - i buh. Robert Mundey for his hould there - i buh. John Hellyer for his ffarme there - v buh. the same John for the parsonage there vij buh. ij qrs. vij buh.

* Woodcott. A small parish on the south side of the North Downs. The manor-honse here was evidently a residence of some importance at this period, and the warrant of the Justices for this assessment is dated from Woodcott, 15 A pril, 1575.

+ Ffarneham-Deane. Now Vernham-Dean, a large hilly parish adjoining Wiltshire. It originally formed part of the manor of Hurstbourne Tarrant.

$\ddagger$ Upp Husborne or Hurstbourne Tarrant. A large village, $5 \frac{1}{2} \mathrm{~m}$. N. by E. of Andover. The adjunct Tarrant is derived from the connection of the place with the nunnery of Tarrant in Dorsetshire, which possessed the manor and tithes of the parish, as also those of Vernham-Dean for several centuries anterior to the reformation. The manor of Hurstbourne Tarrant was granted by Edward VI, to Sir William Powlett, Ist marquis of Winchester, and his heirs for ever, for the maintenance of the fortifications, and an insignificant garrison at Netley Castle-the same little fortalice between the Abbey and Sonthampton Water, originally the gate-house of the abbey, but now occnpied as a private residence. 


\section{TANGLye. *}

Vincent Smith for his hould there - i buh.

John Heathe for his hould there - - i buh.

Thomas Drewlye for his hould there - i buh.

Richard Corderry for his hould there - i buh. $\}$ vj buh.

John Hopgood for his hould there - i buh.

John Mercer for his hould there - - i buh.

Coombe. $\dagger$

John Parker for his hould there - - i buh.

Robert Saunders for his hould there - i buh. di.

John Blake for his hould there - - $\mathrm{i}$ buh. di.

Anthony Boswell for the ffarme - - viij buh.

the same Anthony for his hould at

Nestwicke - - - - - i buh. di.

the same Anthony for the parsonage - $i$ buh. di.

j qrter.

vij buh.

\section{$\left.\begin{array}{c}\text { Sum totall of wheate within } \\ \text { the hundred of Pastroe. }\end{array}\right\} \mathrm{xv}$ quarters wheat.}

For the payment of fiue lambes.

FFACCOMBE.

John Pierce for his hould there - - $\quad$ xijd.

Ambrose Brooker for his hould - - xijd.

$\left.\begin{array}{lll}\text { John Cooper for his hould there - } & - & \text { xijd. } \\ \text { William Deane for his hould there } & - & \text { xijd. }\end{array}\right\}$ iijjs.

FFARNEHAMS-DEANE.

Thomas Smart for his hould there - xijd.

Thomas Brooker for his hould there - xijd.

William Pike for his hould there - xijd.

Edith Bennett for her hould there - $\quad$ xijd.

iiijs.

Husborne.

William Milles for his hould there - $\quad$ xijd.

William Bulpitt for his hould there - xijd.

Robert Jeneway for his hould there - $\quad$ xijd. $\}$ iijjs.

Alice Dowce for her hould there - - $\quad$ xijd.

- Tangley. A scattered village near the borders of Wiltsbire, $5 \mathrm{~m} . \mathbf{N}$.N.W. of Andover. The benefice is consolidated with Faccombe Rectory.

$t$ Coombe. A small village in a deep valley, near the junction of the three connties of Wilts, Berks, and Hants. The manor and nearly all the soil was formerly held by the Priory of Okeburn or Ogbonme St. Cieorge, a cell to the great abbey of Bec in Normandy, Archbishop Lanfranc's home, and granted by Hen. VI. to King's College, Cambridge. 
Tanglye.

William Coxe for his houlde there - $\quad$ xijd.

Christopher Jeffery for his hould there - xijd.

William Mercer for his hould there - xijd.

William Leache for his hould there - $\quad$ xijd.

Coombe.

George Knight for his hould there - $\quad$ xijd.

Thomas Maye for his hould there - xijd.

Simon Smith for his hould there - $\quad$ xijd.

Robert Kempe for his hould there - xijd. J

iijs.

ffor the payment of iij geese.

FFACCOMBE.

Mr. Sweetwell for lande he holdeth there - i.

Thomas Pierce for his hould there - - i.

\section{Lynchenholite.}

Thomas Poore for his hould there - - i. (iij geese.

Woodcotr.

Drewe Rumboll for his hould there - - i.

ffor the payment of iij Capons.

FFACCOMBE.

Richard Wigmore for his hould there - - i.

Mawde Hellyer for her hould there - - i.

LYNCHENHOLTE.

$\begin{array}{llll}\text { Robert Rumboll for his hould there } & - & - & \text { i. } \\ \text { Thomas Kempe for his hould there } & - & - & \text { i. }\end{array}$

WoodcotT.

ffor the payment of vij hennes.

Robert Kente for his hould there - - i.

Rowland Dewman for his hould there - - i.

John Fellow for his hould there - - - i.

John Hedges for his hould there - - - i.

UPPER HUSBORNE

William Crouchman for his hould there hennes i.

William ffarr for his hould there- - - i.

Thomas Hendy for his hould there - - i.

Suma, vij hennes. 
ffor the payment of $x j$ pulletts.

FFARNHAMS DEANE.

William Blissett for his hould there - - i.

John North for his hould there - - - i.

HusBorne.

Edward Portchmouth for his hould there - i.

Humfry Both * for his hould there - - i.

William Skeye for his hould there - - i.

John Rose for his hould there - - - i.

Taxglye.

Robert Crouch for his hould there - - i.

Agnes Wibley for her hould there - - i.

Соомве.

Robert Pierce for his hould there - - i.

Henry Hedges for his hould there - - i.

Henry Rumboll for his hould there - - i.

xj pulletts.

Suma totall within the

hundred of Pastroe.

\begin{tabular}{|c|c|c|}
\hline \multicolumn{3}{|c|}{ Wheate - - Iv quarters. } \\
\hline Money f & for lambes & - $\quad x \times 8$ \\
\hline Geese & - & - \\
\hline Capons & - & - \\
\hline Hennes & - & - \\
\hline Pulletts & - & \\
\hline
\end{tabular}

The hundred of

Ouerton, 1575. ffor the payment of $x \nabla$ qrters. wheate.

Broadlye. $\dagger$

The parson there for the parsonage and for $x \nabla$ ac. Copyhould lando - -

Sir John Saunge, knight, + for the ffarme there - - - - - i qrter.

$$
\left.\begin{array}{l}
\text { ij buh. } \\
\text { i qrter. }
\end{array}\right\} \begin{gathered}
\text { i qr. } \\
\text { ij buh. }
\end{gathered}
$$

- Or Bootb.

$\dagger$ Bradley. A small village and parish, 2 miles W. of Preston Candover, in a detached portion of the Hundred of Overton. The manor was one of those given to the Charch of Winchester by Edward the Elder. At the time of this Purveyance it was held by Sir John Savage in right of his wife, Dame Elinor, widow of Sir Kichard Pexhall, of Beaurepaire, the ancient seat of the Brocas family, who beeame possessed of Bradley by the marriage of Sir Bernard Brocns with Mary, daaghter of Sir John de Roches, and widow of Sir John de Borhunte. It is the manor and rectory of which Agnes, first wife of William Brocas de Bradelegh, was retnrned as seised in 1484. Sir John Savage was of Rocksavage, in the connty of Cheshire, knight. He was the eighth Sir John Savage, knight; ninth in descent from John Savage, who in the reign of Edward III., became in right of lis wife, Margaret Danyers or Daniell, 


\section{Coldwaltham. *}

The parsonage there in the manurance of the parson - - - - James Rumboll for the ffarme there - i quarter. John Twyne for his hould there - - iij buh. Edward Bigges for his hould there - j buh. Rowland Gedge for his hould there - $\mathrm{j}$ buh. James Lamboll for his hould there - $\mathrm{j}$ buh. Gilbert Cobbe for his houlde there - $\mathrm{i}$ buh. Mawde Siluer for her hould there - i buh. Richard Brickledon for his hould there i buh. John Bigges for his houlde there - i buh. Thomas Lamboll for his hould - - $\mathrm{j}$ buh. Clapshowe Widow for her hould - _ ij buh.

iij qrters. iii buh.

* Cold Waltham. This place is marked on Kitchen's Map of Hampshire as "Cold or North Walthan," within the hundred of Orerton. One of the ancient manors of the Bishops of Winchester.

lord of Clifton, a place finely situated at the jnnction of the rivers Mersey and Weaver. His ten children were borne him by Elizabeth Manners, daughter of Thomas, Earl of Rutland, and his career was signalised not only by the erection of the magnificent mansion he called-relinguishing the old nane of Clifton-"Rocksavage," but by serving his country seven times as sheriff, and his county town three times as mayor.-(Burrow's Hist. of the Brocas family). It appears on the calendar of proceedings in the Court of Chancery temp. 2 Elizabeth that Sir John Savage was living in 1595, and that he had purchased considerable estates at Tadley and elsewhere in North Hants, which his second son, Edward, claimed as heir in tail under settlement. Prof. Burrows mentions that the Beaurepaire estates were settled on this Edward Savage, who married a niece of Dame Elinor, (hiz stepmother), by half-blood, if that term can be used by an illegitimate sister's child.The sister's name was Katharine, danghter of Dame Elinor's mother. Her child, Polyxena was her daughter by William le Grig or Grice, "of London, gentleman." In 1629-30 Sir Henry Wallop, the sheriff of Hampshire had a suit in the Star Chaniber with one Thomas Taylor, the then owner of Bradley manor in which Sir John Savage is referred to as "the anthor of all this mischief." Sir Kenelm Digby agreed to invest it "as his Majesty's farmer thereof." Wheu the sheriff went to take possession Mr. Taylor and his wife and sixteen children refused to leave. They "resisted with hrearms, and the sheriff's party answered with ordnance, and made approaches up to the door of the house, but were altinately obliged to retreat." Taylor then petitioned the king, complaining that he was being "stripped out of his estate by the oppression of Sir Kenelm Digby." Sir Kenelm also petitioned, stating that Taylor had with him "a tumultuous body of sailors under the command of a captain, who defended the house in a warlike manner for six or seven hours, and killed one of the sheriff's men with a poisoned bullet." The result of this dispute was that possessions was ultimately rendered to Sir Kenelm Digby. The Savages inter-married with a family named Waterman of Tangley, the Hurstbonrnes, Preston Candover, and other places in North Hants. In the church of Preston Candover Church there is a brass to the Rev. Thomas Waterman, who died in 1726. He was Vicar of this parish 59 years. A branch of the family settled at Holt, in the parish of Kintbury, Berks, one of 


\section{Deane.*}

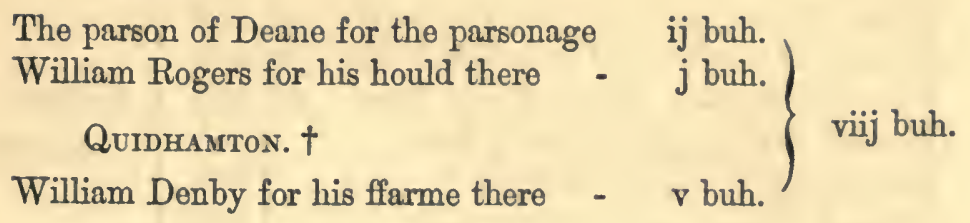

AsHe. $\ddagger$

The parsonage of Ashe for the parsonage there - - - - - -

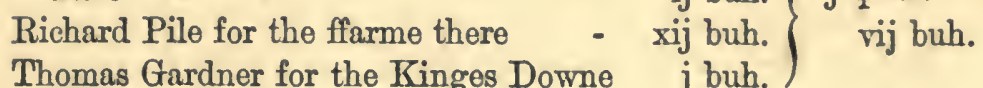

\section{Polhampton. §}

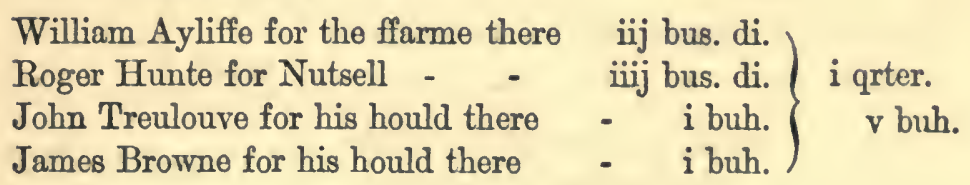

- Deane. A village abont $2 \mathrm{~m}$. E. of Overton. The word Deane is Celtic in its origin, and expresses any quiet or sequestered spot. (See Ashe).

† Quidhampton. A tithing of Overton, on the north side of the valley. The name is derived from the Cornish cuid a wood. Quidham means the "homestead by the wood."

f Ashe. A small scattered parish about $2 \mathrm{~m}$. E. of Whitchurch. The manors of Ashe and Deane were purchased by the celebrated William of Wykeham, about the latter part of the fourteenth century ; and they were left by him to his sister Agnes, in the possession of whose descendants they continued for some time-the son taking the name of Wykehain. The next female heir married Lord Saye and Sele, by the last of whom of that crention, the manors were alienated; and though they have often changed proprictors since that time, they have never retarned to the descendants of any relation of Wykeham. In 1607 Sir James Deane endowed the almshouses he founded at Basingstoke with a rent charge of $£ 55$ out of the manor or farm at Ashe. The nanor of Dean passed from Sir James Dean, knt., by the marriage of his danghter or niece, temp Car. 1, to John Harwood, Esq., whose family long possessed it.

\$ Polhampton. A tithing of Overton parish. According to Rudborne, this was one of the nine nianors by the gift of which Alwyn testified his gratitude at the demonstration of his innocence by Queen Emma's deliverance.

whom John Waterman, born in 1625, married Elizabeth, daughter to Richard Blandy, of Holt, of the aucient Berkshire family of this name, long settled at Inglewood in the same parish. His son Blandy Waterman is mentioned in the Herald's Visitation of Berks as aged $13 \mathrm{in} 1665$. 'The name is perpetuated in "Waterman's Farm," near Holt Manor. Dorothy, dau. of John Waterman, of Tangley, married Dorothy, dau. of John Hasker. Some notice of the latter family will be found under Monks' Sherborne. It may be mentioned that in Stevens' History of St. Mary Bowrne this Bradley is confused with a Bradley Farm in that ncighbourhood. 


\section{Southanton. *}

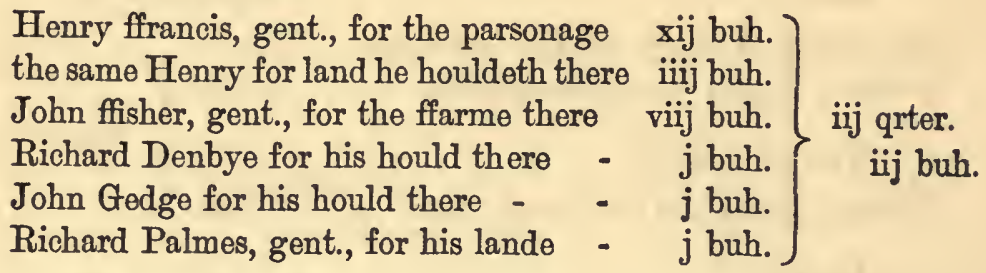

Norrington. $\dagger$

Rumboll Wadlowe for his ffarme there $j$ quarter.

LAUERSTOCKE. $\ddagger$

Gregory Mathew for the ffarme thare i qrter. the psone for the parsonage there -

TADleye. §

Reynold Hanington for that he holdeth there

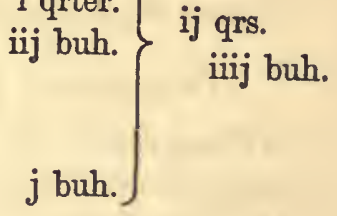

$\left.\begin{array}{c}\text { Suma totall of wheat within } \\ \text { the hundred of Overton. }\end{array}\right\}$ xv. qrters. wheat.

ffor the payment of $x$ lambes.

Bradley.

the ffarme there in the occupacon of Sr. John Sauage

Knight - - - - - - - - - iiijs.

* Southanton. Now Southington, extending southward from the town of Overton. Southington is now the residence of W. W. Portal, Esq.

+ Now Northington, a farm in the parish of Overton.

‡ The Lavrochestock of Domesday, then held by the monks of St. Peter at Hyde, Winchester, a picturesqua parish in the Test Valley, about a mile W. of Overton. The parish contains about 2,000 acres of land, nearly all the property of Melville Portal, Esq., M. P. for North Hants, 1849-1857, of Laverstoke House, a large and handsome mansion, in a well-wooded park. The old mansion was bnilt abont 1600 , and was taken down and rebuilt on a larger scale in 1800, by Henry Portal, Esq., uncle of the present owner. The Portals were one of the oldest and most distinguished families in Languedoc. Being expelled from France after the revocation of the Edict of Nantes, in consequence of their active participation in favour of the Protestant cause, they took refuge in England, in the latter part of the seventeenth century, and have ever since resided at Laverstoke, where, and in the adjacent parishes of Overton, Freefolk, and Whitcharch, they have large estates, Here they established a Paper Mill, at which all the Bank of England Note Paper has been manufactured since 1719 , but was previonsly carried on at Bare or Bere Corn Mill in the parish of Freefolk Manor, which was built in 1710 , by one of the Portal family. Laverstoke Bank Note Paper Mills now belong to Wyndham S. Portal, Esq., of Malshanger.

$\$$ Tadley. A scattered parish about $6 \mathrm{~m}$. E. by N. of Kingsclere. Tadley Place was the ancient seat of the Ludlows in Hampshire. and "Wyford" of the Moores, a very old family in these parts. 
Ashe.

Thomas Gardner for Kinges Quime - - - - iiijs.

Richard Pile for the ffarme there - - - - iiijs.

Quidhamton.

ffrancis Palmes, gent., for the land he holdeth there - iiijs.

Polmampton.

Roger Hunte for Nutsell - - - _ _ - iijjs.

SouthamTon.

John ffisher, gent., for the ffarme there - - - iiijs.

Philip Nashe for his hould there, and John ffranklin for

his houlde there betwoen them - _ _ - iiijs.

NoRTHINTON.

Rumboll Wadlowe for his ffarme there - - - iijs.

TADLEYE.

Genge Ludlow, Esq., for his land there - - - - viijs.

Sum : xls.

ffor the payment of viij geese.

TADLEYe.

$\begin{array}{llr}\text { Reynold Hanington for his hould there } & - & \text { i } \\ \text { William Apleton for his hould there - } & - & \text { ij }\end{array}$

Henry Prior, jun., for his hould there - - i

Richard Sherland for his hould there - $\quad$ - i viij geese.

Robert Still for his hould there - - - i

Henry Prior for his hould there - - - i

Richard Sheffield for his hould there - - i

ffor the payment of viij Capons.

LAUERSTOCKe.

Thomas Dauy for his hould there - $\quad$ i

Christian Mason for her hould - - - i

Gregory Mathew for his hould there - - i

Edward Heywood for his hould there - - i

Thomas Penton * for his hould there - _ i triij Capons

Hugh Wadlow for his hould there - - i

Deane.

Richard Winckworth for his hould there - ij

* The Pentons were a family of old establishment as Winchester citizens. 
ffor the payment of xiij hennes.

Bradlet.

William ffinden for his hould there $\quad-\quad$ i

Waltham.

Mowde Wareham for her hould there - - i

Julian Purchase for his hould there - - i

Deane.

John Basse for his hould there - - -

William Small for his hould there $\quad$ - $\quad$ - i xiij hennes.

Richard Small for his hould there - - - ij

Waltham.

John Woodman for his hould there - - i

Polhamton.

Margery Berry for her hould there - - ij

George Knight for his hould there - - $\quad$ ij

ffor the payment of $\mathrm{xxj}$. pulletts.

Colwaltham.

William Searle for his hould there - i.

John Bigges for his hould there - $\quad$ i.

Robert Hughes for his hould there - i.

Polmamton.

Richard Edmonde for his hould there -

Simon Goodale for his hould there -

George Oulding for his hould there -

William Ailiffe for his hould there - $\quad$ i.

Deane.

William Garrett for his hould there - i.

Baldwine Garrett for his houlde $\quad$ - i.

Southanton.

Rose ffinkelye for her hould there - $\quad$ i.

Nicholas Harte for his hould there - i. ?

LAUERSTOCKe.

Edward Heywood for his hould there William Luke for his hould there -

John Gilbert for his hould there

Hugh Wadlow for his hould there

$\left.\begin{array}{l}\text { ij. } \\ \text { ij. } \\ \text { j. } \\ \text {. }\end{array}\right\}$

.

i.

$\left.\begin{array}{l}\text { i. } \\ \text { i. } \\ \text { i. }\end{array}\right\}$ 
Ouerton.*

$\left.\begin{array}{lll}\text { John Dowse, sen., for his hould } & - & \text { ij. } \\ \text { John Magewicke t for his hould } & - & \text { i. }\end{array}\right\}$

TADLYE.

Thomas Prior for his hould there - $\quad$ i.

Suma : xxj pulletts.

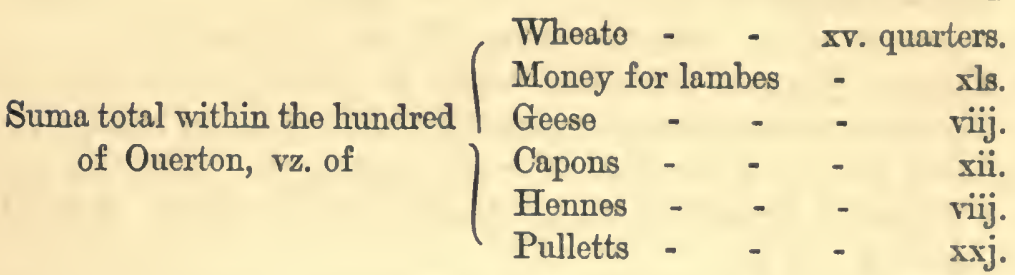

The hundred of KingscLere, 1575.

A perfect booke of all the landes as well arable as pastures, meadows, woodes and waste grounds, with the goodness of the same, as well as in whose handes and occupacion the same is, within the hundred of Kingsclere, vewed scene and numbred by estimacon; the xxvth of April, 1575 ; as ffoloweth: by certeine inhabitants there, whose names or heer under written; at the comandment of the Justices of the Peace of our Soueraigne Lady the Queenes matie within her graces' county of Southn. And furthermore how mutch, and upon whome, the whole sume and Rate of wheate, Sturtes, Lambes and Poultrye, thereby may best be leauyed for purvision of the Queenes Maties. most honourable householde, at sutch time as the same shalbe requested.

EARLSTONE.

The ffarme of Eariston by estimacon, of errable land in the ffieldes 120 ac. of pasture ground, 60 a. of meadow ground, 35 acs. of wood ground, 50 ac.

Edward Withers, of errable land in the fieldes, $\mathbf{x x}$ ac. of pasture ground, ij acs. of meadow ground, $\nabla$. ac.

* Overton. A large village in the valley of the river Test, $4 \mathrm{~m} . \mathrm{E} . \mathrm{by} . \mathrm{N}$. of Whitchurch. Quidhampton and Polhampton are tithings in this parish. The manor of Overton was given to the Churcls of Wincliester by Edwand the Elder, and the bishops of the See are still lords of the manor.

+ This name is still a familiar one in the district. 
James Mason, of errable land in the fieldes viij ac., of pasture ground iiij ac., of meadow ground $j$ ac.

George Mason, of errable land in the fieldes xiiij ac., of pasture ground $x v$ ac., of meadow ground $\nabla$ ac., of woods iij ac.

John Leggatt, of pasture ground $\nabla$ ac., of meadow 2 ac.

John Palmer, of errable landes in the fieldes viij ac., of pasture grounde vj ac., of meadow ground $i j$ ac.

William Wither, of errable landes in the fieldes xiiij ac., of pasture ground $\mathrm{xV}$ ac., of meadow ground iiij ac., of woodes iiij ac.

Margaret Withers, of arrable landes in the ffieldes $\mathrm{xxx}$ ac., of pasture ground xxx ac., of meadow ground viij ac., of woods $\mathrm{v}$ ac.

James Hunte for Gudgins, of errable land in the ffildes $\mathrm{xxx}$ ac., of pasture ground xl ac., of meadow ground xij ac., of wood ground xviij ac.

Edmond Cooke, in Nockhouse, of errable and pasture lx ac., of meadow ground viij ac.

Suma totall within Earlstone of errable, pasture, meadow, and woode - _ 644 ac.

\section{Sxdmanton.}

John Hardinge, of errable lands in the ffieldes viij ac., of pasture ground xviij ac., of medow ground vj ac., of woodes ij. ac.

John Millett, of errable land in the ffieldes $\mathrm{v}$ ac., of pasture ground $x$ ac., of medow ground iij ac., of wood ij ac.

John Knowle, of errable land in the ffieldes $\mathbf{x}$ ac., of pasture ground viij ac., of wood $\mathrm{j}$ ac.

Alice Nutt, of errable land in the ffieldes viij ac., of pasture ground xij ac., of medow ground ij ac.

Thomas Smith, of pasture ground and arrable xx ac., of medow ground $\mathrm{ij}$ ac.

Richard Rowland of errable landes in the field $\mathrm{v}$ ac., of pasture ground vj ac., of medow ground ij ac., of wood ground ij ac.

Thomas Mason, of Collett's, of errable land in the fieldes $\mathrm{x}$ ac., of pasture ground viij ac., of medow ground ij ac.

Edmund Mason, of errable landes in the ffieldes iij ac., of pasture ground $\mathbf{v}$ ac., of medow ground $\mathbf{j}$ ac., of wood $\mathbf{j}$ ac.

Henry boyer, ${ }^{*}$ of errable land in the fieldes $\mathrm{x}$ ac., of pasture ground xiiij ac., of medow ground $\mathrm{ij}$ ac., of wood $\mathrm{j}$ ac.

* The name of Boyer is not often found in this district, but in the adjoining county of Sussex, we find a Ralph Boyer, M.P.; for Arundel, 1555, and John, M.P. for Steyning, 1547. There was a family of the same long settled at Hartheld in Sussex. In 1752 the Boyers were paper makers at Whitchurch. 
John Mason, of errable land in the ffieldes xvij ac., of pasture ground xix ac., of medowe ground $\mathrm{j}$ ac., of wood $\mathrm{ij}$ ac.

Thomas Mason, of Aynoldes, of errable land in the ffieldes xxxvj ac., of pasture ground viij ac., of medow ground $j$ ac.

Walter Salter, of errable land in the fieldes $v$ ac., of pasture ground xij ac., of medow ground ij ac.

Cambers of errable land in the fieldes xxriij ac., of pasture ground xlvj ac., of wood ground $\mathrm{xx}$ ac.

John Josye, of errable land in the fieldes xv. ac., of pasture and medow $\mathrm{j}$ ac.

Robert Mason, of errable land in the fieldes $x \nabla$ ac., of wood ground $\mathrm{j}$ ac.

William Martine, of errable land in the fieldes $\nabla$ ac., and of Sandleford land $\mathrm{v}$ ac. *

William Sanders, of errable land in the ffieldes xiiij ac., of pasture ground iij ac.

John Wallis, of errable land in the ffieldes $\mathrm{xV}$ ac. of pasture and medow ground vj ac.

Stephen Dancastle, $\dagger$ of errable land in the ffieldes xvij ac., of pasture and medow ground $\mathrm{j}$ ac.

John Turton, of errable land in the ffieldes $x v$ ac.

Richard King, of errable land in the ffieldes xv ac.

Richard Wallis, of errable land in the ffieldes $x v$ ac., of pasture and medow ij ac.

\section{Edmoxstrop Launcelewill. $\ddagger$}

Nicholas Knight, for Holdip hill, of errable in the fieldes iij ac., of pasture ground xxvj ac., of medow ground $\mathrm{v}$ ac.

Walter Knight, of errable in the ffieldes xiiij ac., of modow vj ac., of pasture ground xxvj ac., of woodes iiij ac.

Nicholas Wigmore, of errable land in the ffieldes xvij ac., of pasture ground xxxij ac., of medow vj ac., of wood iijj ac.

- Land belonging to the Priory of Sandleford, near Newbary, founded by Geoffrey, Earl of Perche, Earl Marshal of England, and Maud his wife, abont the year 1200 .

\$ The Dancastles, an ancient Roman Catholic faully in Berkshire, were long seated at Wellhoase in the parish of Hampstead Norris, the Grange in the parish of Shaw, and at Binfield, and were allied to the Eystons of Hendred and other families who ahered to the old religion. A John Dankastell, of Hannstead-Marshall was a scholar of Winchester College in 1412.

t So-called from the Laancletta, Lanncelewills, or Ianucelevees, a name most varied in its prononnciation and orthography. They were an ancient family, whose names are found in connection with several properties in Hanpshire. Their old manor-honse, now a farm, sarrounded by a moat, two miles east of Sherfield-on-Loddon still bears their name. 
John Reynoldes, of errable land in the ffieldes $j$ ac., of pasture ground xiiij ac., of medow ground $\mathrm{v}$ ac.

Walter Spencer, of pasture ground $x$ ac., and medow iij ac.

John Louelocke* of pasture ground $\mathrm{xv}$ ac. and medow iij ac.

\section{Edmonstrop Beenam.}

The ffarme of Edmonstrop, of pasture and errable land 130 ac., of medow ground $\nabla$ ac., of wood ground viij ac.

Richard Wayte, $\dagger$ of pasture and errable land vij ac., of medow $j$ ac.

Thomas Wayte, of Westlandes, of pasture and errable land $\mathrm{xx}$ ac., of medow ground vj ac., of wood ground $\mathrm{xx}$ ac.

Walter Mace, of pasture and errable land xxviij ac., of medow ground ij ac., of wood ground ij ac.

John Batcheler, of pasture and errable land v. ac.

Ingram Batcheler, for East Croftes, of pasture and errable land xx ac., of medow iij ac.

Henry Wither, for Strottons, $\ddagger$ of pasture ground $\mathrm{xx}$ ac., of medow ground ij ac., of wood ground ij ac.

John Lawrence, for Scrouchis $\S$ and burne land, of pasture and errable $\mathrm{xx}$ ac., of wood ground $\mathrm{x}$ ac.

Margaret Butler, of pasture and errable land viij ac.

John Chamberleine, for Pitchornell of pasture and errable land xxvj ac., of wood ground ij ac., of medow ground iij ao.

* Lovelock is the name of a family which from this date to the present day has always had its representatives engaged in agricnlture, and the name occurs very frequently in the reristers of Vernham Dean, Faccombe, Kingsclere, and other North Hampshire parishes. The names of some of this old yeomen stock appear as having served as troopers in the reviment of horse raised by the Kingsmills, of Sydmonton at the time of the Civil War. and one of them, Mr. James Lovelocke was amongst the prisoners taken at the second battle of Newbury by the Parliamentary army. A branch of the family has been long settled in the parish of Shaw, near Newbary, where a vell-known representative still resides.

+ There is a holding in Kingsclere parish still known as Wajtes or Wait's farm.

† Now-known as "Strattons." Thomas Wither, of Manydown, who died in 1507, married Joan, danghter of Kichard Mason, of Sydmonton, and among other children had 1. Johm who sncceeded to Manydown, and died in 1536; 2. Richard, of Sydmonton, and 3. Thomas, of Earlstone. Richard's Will is at Winchester, in which he is described as of Wherwell. In two Inquisitions post mortem dated respectively 1570 and 1602 , mention is made that the son and grandson of Richard, viz.: Johm and Henry owned about 120 acres in Kingsclere, and Earlstone, called Apshanger, Stracton Magna, here written "Strottons," Holl Close, and Roodebreach. The premises in Earlstone appear to have been copyloold, for they were held "of Richard Fynes, Esquire, Knight, by suit of court of his manor of Erleston."

$\S$ This name is still retained as part of Strattons, and is well known to hnnting men for its swampy pitfalls.

\| This name still sarvives. 
Nicholas Millett, for Pitchorne of pasture and errable land x ac., of wood ground ij ac.

James Hunte, for Apshanger, ${ }^{*}$ of errable landes in the ffieldes 80 ac., of pasture ground viij ac.

Robert Mason, for Cooke's land, of errable, pasture ground iij ac., of medow ground ij ac.

\section{The Gyldable.}

the Inne called the Crowne + in the occupacon of Nicholas Clapham, of errable land in the ffieldes $\mathrm{xx}$ ac.

\section{CleRe WoodcotT. $\ddagger$}

Nicholas Knight, for ij Copihouldes in the same tything of arable and pasture ground viij ac., of medow ground $\mathrm{j}$ ac.

James Hunte, for Gillman's, of errable and pasture xvj ac., of medow ground iiij ac.

William Spencer, of errable and pasture ground viij ac.

Thomas Edwardes, of errable and pasture ground viij ac.

Richard Webb, for Knowle-hill ffarme of errable land in the ffieldes xl ac., of pasture ground l ac., of medow ground iij ac., of wood ground vij ac.

Richard Webbe, for the ground called pastor's lands rj ac.

\section{Hanitox Lauxces.}

the ffarme called Haniton Launces, in the handes of Henry Kingsmill, Esq., ?§, of errable land in the comon fieldes lxx ac., of errable and pasture ground together in severall 120 ac., of medow ground ij ac., of wood ground 80 ac.

John Tyler, otherwise called Fletcher, of errable land in the ffieldes $\mathrm{xxx}$ ac., of pasture ground $\mathrm{xxx}$ ao., of medow ground vij ac.

Peter Thorne, for Haningtone, errable lande $\mathrm{x}$ ac.

Edward Brewer, for Bonfieldes, errable land $\nabla$ ac.

- Apshanger land is about one mile ont of Kingsclere toward Highclere.

t This ancient hostelry is still flourishing as the "Crown" but the old gabled and picturesque building of former days has been supplanted by a modern representative.

I The tithing of Clere Woolcott comprises Knowle Hill Farn, Harridans, and Hall Farms, and Rau Alley Famu. These properties commence by Elm Grove, and ran by the Reading Koad down to Kungsclere Woodlands.

$\S$ Henry Kingsmill, Esq. Afterwards Sir Henry Kingsmill. In Kingsclere Church there is an elnborate altar-tomb with effigies of Sir Henry, who died in 1624, and his wife, Bridget, danghter and co-heir of John White, Esq., of Soutluwick, near Fareham, who survired her lusband 48 years, dying in 1672. 


\section{Ewhurste.}

Richard Aylife * for the ffarme of Ewhurste, of errable land lxxx ac., of pasture ground lxxx ac., of medow ground viij ac., of wood ground $\mathrm{xl}$ ac.

Richard Ayliffe for ffinley, of pasture and errable ground xl ac., of medow ground vj ac., of wood ground $\mathrm{xx}$ ac.

\section{WoljLERTON.}

the ffarme of Wollferton in the handes of Thomas Gardner, of errable land 180 ac., of pasture ground $\mathrm{lx}$ ac., of medow ground $\mathrm{x}$ ac., of wood ground lv ac.

Robert Heron for the parsonage of Wolferton, of gleebe land in the comon fieldes xxvj ac., of pasture and errable inclosed liiij ac., of wood ground iij ac., the tythes of the parsonage of Wollferton.

John Butler, of errable land in the comon fieldes xxxvj ac., of pasture ground lvj ac., of medow ground iij ac., of wood ground xvj ac.

Hugh Keene, of errable land in the ffieldes $x x x v$ ac., of pasture ground xxxij ac., of medow ground iij ac.

Alexander Smith, of errable land in the fieldes vj ac., of pasture ground xviij ac.

Robert Gedge, $\dagger$ of errable land in the fieldes xij ac., of pasture ground xj ac., of medow ground $\mathrm{j}$ ac., of wood ground vj ac.

Lawrence Still, of errable land in the fieldes 98 ac., of pasture ground xviij ac., of medow ground $j$ ac.

John Humber, $\ddagger$ of errable land in the ffieldes xviij ac., of pasture ground xxiiij ac., of medow ground iij ac.

* Richard Aylife. There is a pedigree of this family, long settled at Nateley-Scnres, in the Visitation of 1634. In $1535 \mathrm{John} A$ ylife was rector of Sherborne St. John, and beld the valuable prebendary of Southeram. Richard Aylife, of Nateley-Scares, was one of the executors of the will of William Warham, Archbishop of Canterbury. He had three sons-Thomas, William, and Robert. Thomas was father of Richard Aylife, of Nateley-Scures, who, by his wife Elizabeth, daughter of Nicholas Venables, of Andover, had two sons Thomas and Ricbard Aylife. Kobert Aylife was father of Bryan Aylife, whose son Richard married Dorothy, danghter of Edward Fanconer, of Kings* clere. Among the Hampshire pilgrims to the English College at Rouse, in 1557, was Richard Aylife, of Nateley Scures. George Ayliffe was of Southington in 1602 .

+ The name of Jobn Gege or Gedge, of Hannington occnrs on the roll of Winchester Scholars in 1514. "Winchester Scholars," by Thos. Fredk Kirby, M.A., Bursar of Winchester Coll.

I This name which has acquirea a wide celebrity in connection with the bicycle manufacture is a very uncommon one in the South of England, and we do not remember having net with it before in this district. 
Margaret Buttler, of pasture and errable ground xlviij ac., of medow ground $i j$ ac., of wood ground iij ac.

Thomas Meye of pasture and errable land xxij ac. of medow ground $\mathrm{j}$ ac., of wood ground $\mathrm{j}$ ac.

William Spencer, of pasture and errable ground within this tythynge, but $\mathrm{v}$ ac. and his howse standeth upon Wollferton.

William Silrester, of errable land in the ffieldes $x$ ac., of pasture and errable ground $x$ viij ac., of medow $j$ ac.

Thomas Prior, of errable land in the ffieldes viij ac., of pasture ground iij ac.

John Humber, tayler, " of errable land in the ffieldes viij ac.

George Hunte, of errable lande in the ffieldes rij ao., of pasture ground iij ac.

\section{SANDFORDE.}

the ffarme called Sandford in the handes of Isabell Hunte, of errable land in the comon ffieldes 1 ac., of pasture ground and errable inclosed 160 ac., of medow ground $\mathrm{xxx}$ ac., of wood ground lxxx ac.

John Mason, of errable land in the ffieldes $\mathrm{xx}$ ac., of pasture ground $\operatorname{xxx}$ ac., of medow ground viii ac., of wood ground ij ac. Hugh Isarne, + of errable and pasture ground ix ac., of medow $\mathbf{x}$ ac.

Ingram Willmot, of errable and pasture ground xv ac., of medow ground $\mathrm{ij}$ ac., of wood ground $\mathrm{j}$ ac.

James fforde, of ermble land in the ffieldes $x$ ac., of pasture ground viij ac., of medow ground $i j$ ac., of wood ground $j$ ac.

Thomas Earlye, of errable and pasture ground viii ac., of medow ground ij ac., of wood ground ij ad.

Thomas Hogge, of errable land in the ffieldes iij ac., of pasture ground $\mathbf{x \times \nabla}$ ac., of medow ground $\mathrm{j}$ ac. of wood ground ij ac.

Nicholas ffickus, of errable land in the ffieldes iiij a.., of pasture ground $\mathrm{xxV}$ ac., of medow ground $\mathrm{j}$ ac., of wood ground $\mathrm{j}$ ac.

Thomas Weste, of pasture ground and errable viij ac., of medow ground iij ac.

John Apleton, of pasture and errable ground xij ac.

James Hunt, for Galis, of errable and pasture ground $\mathrm{v}$ ac.

William Spackman, for Galis, of errable and pasture ground $\mathbf{x}$ a.

"The description of John Hamber as "tayler" indicates that all classes of the inhabitants held rllotments in the common fields.

$t$ Isarne or Izorue is a name which occars in the neighbourhood as early as 1545 . 
Edward Aberry, of errable and pasture ground $x$ ac.

Robert Purdue, of errable and pasture ground $x \nabla$ ac., of medow ground $\mathrm{ij}$ ac.

William Osmonde, of errable and pasture ground $x \nabla$ ac., of medow ground $j$ ac.

Anne ffrowde, of errable land in the ffeildes iiij ac., of pasture and errable land inclosed $\mathrm{xxx}$ ac., of medow ground $\mathrm{ij}$ ac

Thomas Dyer, of errable land in the ffieldes iij ac., pasture and errable land inclosed xl ac., of meadow ground $\mathrm{ij}$ ac., of wood ground $\mathbf{j}$ ac.

William Dyer for Burchett, of pasture ground viij ac., of medow ground iij ac.

William Dyer for Swaynes, of pasture ground vj ac., of medow ground $j$ ac.

William Dyer for Longes meade ij ac., of errable land vj ac.

William Ilslye, of errable and pasture ground vj ac.

Thomas Parr, of errable and pasture ground vij ac.

John Cursell, of errable and pasture ground $\mathrm{v}$ ac.

FFROWBERYE.

the ffarme of ffrowbery in the occupacon of James Hunte, of errable land in the ffieldes $\mathrm{lx}$ ac., of errable pasture ground Lxxxv ac., of medow ground xv ac., of wood ground xxxiiij ac.

John Camber, ${ }^{*}$ of errable land in the ffieldes $i j$ ac., of pasture ground $\mathrm{xx}$ ac., of medow ground $\mathrm{j}$ ac.

Richard Knight, gent., of errable land in the ffieldes $x x$ ac., of pasture ground $x l$ ac., of medow ground $x$ ac., of wood ij ac.

George Hunte, of errable land in the ffieldes xxxv ac., of pasture ground $\mathrm{l}$ ac., of medow ground $\mathrm{v}$ ac., of wood $\mathrm{ij}$ ac.

Henry Smith, of errable land in the ffieldes xij ac., of pasture ground $\mathrm{xl}$ ac., of medow ground $\mathrm{x}$ ac., of wood ground ij ac.

Henry Smithe, of Chappell lande, $\dagger$ errable in the ffieldes, 18 a.., of pasture ground $x$ ac., of medow ground $j$ ac.

William Spackman, $\ddagger$ of errable land vj ac., of pasture ground $\mathrm{x}$ ac.

* John Camber was a well-known clothier at Newbury at this period.

$\dagger$ The lands belonging to the aucient chapel, the remains of which are still standing near the farm-house, formerly a residence of some importance, and where King Charles I. was quartered in Oct. 1644.

$\ddagger$ The family of Spackman from this date and possibly earlier till quite recently never failed to have its representative in the parish of Kingsclere, and those evidently of much respectability. Mr. William Spacknan, the last of his name of Kingsclere, fornerly of Plantation farm, died not long since, but members of his family still reside at Eastbury near Lambourn. 
Richard Wrenne, of errable land in the ffeldes $x$ ac., of pasture ground ix ac., of medow ground ij ac.

Walter Prior, ${ }^{*}$ of errable land in the ffieldes iij ac., of pasture iij ac. The land of William Deane, of errable pasture ground $\nabla$ a..

Thomas Apulton, of errable pasture ground x ac.

\section{The Lorpship of Kingscirare.}

the ffarme called Canon Courte, of errable land in the ffieldes 140 ac., of crrable and pasture upon the downes 400 ac., of pasture ground beneath the hill $\mathrm{v}$ ac., of medow ground rij ac., of wood ground $\mathrm{x}$ ac.

Peter ffawkner, geut., $\dagger$ of errable land in the ffieldes 120 ac., of pasture ground $\mathbf{x l}$ ac., of medow ground xvj ac., of wood ground vij ac.

John Hinwood, of errable land in the ffieldes 1 ac., of pasture ground $\mathrm{l} x$ ac., whereof $\mathrm{xv}$ of them are houlden of the said Peter ffawkner, of medow ground iij ac., of wood ground xiiij ac.

William Spencer, of errable lande in the ffieldes $\mathbf{x l}$ ac., of pasture ground xviij ac., of medow ground $i j$ ac.

John Attfield, of crrable pasture ground $\mathbf{x l}$ ac., of medow ground vj ac., of wood ground ijj ac.

Elizabeth Atfield, of errable pasture ground xx ac., of meadow ground ij ac., of wood ground v. ac.

Edmond Sherland, of Atfieldes land, of errable pasture ground $\nabla$ ac., of medow ground $\mathrm{j}$ ac.

Richard Wayte, of Atfieldes land, of erroble pasture ground iij ac., of medow ground $j$ ac.

Thomas Spencer, of $\mathrm{Atfieldes}$ land, of errable land in the ffieldes $\mathbf{x}$ ac., of medow ground $\mathrm{j}$ ac.

- Prior is the name of a family which is to be foand from this period down to the present day, and the old line is still worthily represented in the parish of Kingsclere.

$t$ Peter Fanconer. The name of Ralph le Fanconer occurs in a urant of 1263, relating to $W_{y} k e$ or Weck manor, St. Mary Bourne. In 1552 Kichard Fauconer was seated at Hurstbourne Priors, of which mention occurs in the Visitation of Hampshire that year. He married Elinor, daughter of George Ranbrigge, stated as of Pembridge, co. Hants, by whom he had Richard Fanconer, of Hnrstbourne, who d. 8. p., and two danghters Elizabeth nud Margaret, the latter narried to Willian Sutwell, of Chnte. Alice, sister aud co-heir of Richard Fanconer, married Richard Kingsmill, surveyor or attorney of the Conrt of Wards. The Peter Fanconer mentioned above was the son of Thomas Fanconer, of Kingsclere, by his wife Elizabeth, daughter of John atfield. Il married Jane, dasnghter of Nicholas Withers, of Sydmonton, by whom he hal a son, John Fanconer, married to Catherine, daughter of John Apleton, of Kingsclere. This branch of the fanily was settled at Kingsclere during eight generations. 
Nicholas Knight, for the Swan, * of errable land in the ffeildes lox ac., whereof in the handes of Tristram Spackman xv ac., and in the handes of Ingram Wrenn, of the same land $\mathrm{v}$ ac.

Stephen Knight, for his ffreeland, of errable land in the ffieldes xij ac.

Simon Holdip, $\dagger$ of errable land in the ffieldes $\mathbf{x x}$ ac., whereof in the handes of his mother, the third pte., and for Wheeler's land, of pasture ground iiij ac.

Robert Warham, $\ddagger$ for his copyhould in the towne, of errable lande in the ffieldes $x \nabla$. ac.

Robert Warham for his howse, of errable pasture ground $\mathbf{x v}$ ac.

William Golding, of errable land in the ffieldes viij ac.

Thomas Edwardes, of errable and pasture ground vi ac.

John Howse, of arable land in the ffieldes vj ac.

Robert Cooper, of errable land in the ffieldes xij ac.

James Holdip, of errable land in the ffieldes vj ac.

Peter Hunte, of errable land in the ffieldes xx. ac.

Walter Dicker, of arable pasture ground $\mathrm{xv}$ ac.

ffurthe ffieldes $\S$ in the handes of John Bye, gent., of errable pasture ground $\mathrm{xx}$ ac., of medow ground ij ac.

John Earlye, for the house holden of Peter ffawkner at Kitt's

Court, of errable pasture ground v. ac.

Walter Willmott, of errable pasture ground iiij ac.

Nicholas Wigmore, for his hould of errable pasture zvj ac.

Nicholas Wigmore, for Redeons land, of errable pasture ground $\mathbf{x x}$ ac., of medow ground $\mathbf{v j}$ ac., of wood ground $\mathbf{x x x}$ ac.

* The Swan. This ancient hostelry is still to the fore at Kingsclere, and from time out of mind, has been the property of St. Mary's College, Winchester. This and the "Crown" must be two of the oldest licensed houses in the country. Mr. T. F. Kirby, M.A., F.S.A., Barsar of Winchester College, has been good enough to point ont that Charters of Privilege exempted the College from this burden of purveyance, but the purveyors were always "trying it on," and at one time a Charter of Privilege was kept at Harmondsworth, where the College had property, in order to show to purveyors when they came there. With regard to the "Swan" property Mr. Kirby mentions that he does not think the exemption from purveyance by the Charters of Privilege extended to the Lesees of the College property, and the "Swan" was nndoubtedly let on bcneficial lease to lessees who andertook to bear all burdens. The same was the case as regards Subsidies, the exemption of the College from which did not extend to their lessees.

+ Sinon Holdip, probably a son of this tenant, was a scholar of Winchester College in 1587, and a Nicholas Holdip in 1571. The former was Rector of Ashe and Deane in 1602. He married Patience Dowse. This name is still a familiar, one in Kingsclere as "Holdup."

$\ddagger$ Robert Warham. This appears to have been a nephew of William Warbain, Archbishop of Canterbary.

$\$$ Probably what is now known as "Frith farm." 
William Longe, of errable pasture ground iij ac., of medow ground $\mathrm{j}$ ac.

John Strike, of errable pasture ground viij ac., of medow ground iij ac., of wood ground iij ac.

Robert Bachelor, of errable pasture ground $\mathbf{x x y}$ ac., of medow ground vj ac., of wood ground iij ac.

William Wyatt, of errable pasture ground xij ac., of medow ground $\mathrm{j}$ ac., of wood ground $\mathrm{j}$ ac.

Richard Collman, of errable pasture ground iiij ac.

William Hinde, junr., of errable pasture ground ij ac.

Thomas Hawkins, of errable pasture ground xl ac., of medow ground vj ac., of wood ground $\mathrm{j}$ ae.

John Hunte, for Newlandes, of errable pasture ground lx ac., of meadow ground xi. ac.

John Hide, for Tucker's hill, of errable pasture ground xl ac., of wood ground iij ac.

William Hinde, senr., of errable pasture ground iij ac.

Michael Allen, of errable pasture ground $\mathrm{v}$ ac.

Thomas Meye, of errable pasture ground xvj ac.

Thomas Gardner, for Somerhurst, " of errable pasture ground xl ac., of medow ground iiij ac., of wood ground ij ac., whereof in the handes of John Willis xij ac.

John Willis, for the howse of Henry Smithe at the townes ende, of errable land in the ffieldes vj ac., of medow ground $j$ ac.

Ingram Bachelor, of errable pasture ground $\mathrm{xx}$ ac., of medowe ground iiij ac., of wood ground ij ac.

William Meryett holdeth of George Hunte, of errable pasture vj ac., of errable land in the fieldes vj ac.

George Hunte, for Rydings, $\dagger$ of errable pasture ground xiiij ac., of medow ground $\mathrm{j}$ ac., of wood ground $\mathrm{ij}$ ac.

Robert Mason, for Starkers, $\ddagger$ of errable pasture ground 1 ac., of medow ground ij ac., of wood ground vj ac.

Anthony Currant, of errable pasture ground $\mathbf{v}$ ac.

John Stacye, of errable pasture ground viij a., of medow ground iij ac., of wood ground $\mathbf{j}$ ac.

Thomas Batcheler, of errable pasture ground $\mathrm{xxx}$ ac., of medow ground iiij ac., of wood ground $\mathrm{j}$ ac.

* This farm still bears the name of Summerhurst.

t Rydings, now called Riddinga.

f Starkers, now Starke house. 
Nicholas ffrowde, ${ }^{*}$ of errable pasture ground $x \times x$ ac., of medow ground iij ac.

Thomas Legatt, of errable pasture ground iiij ac., of medow ground j ac.

John Wayte, of errable pasture ground viij ac., of medow ground j ac.

Thomas Wayte, of errable pasture ground $\mathrm{xx}$ ac., of medow ground ij ac.

Edward Aberye for Rydings, of errable pasture ground xij ac., of medow ground ij ac.

Ingram Wrenne for Lydnolls, of errable pasture ground iiij ac., of medow ground $\mathrm{j}$ ac.

Stanton hould in the occupacon of Stephen Knight, of errable land in the fieldes ix ac., of errable pasture ground vj ac., of wood ground iij ac.

Rauenings, of errable land in the ffieldes ix ac.

James Knight for Stantons $†$ ground of errable land in the ffieldes iiij ac., of errable pasture ground $\nabla$ ac., of medow ground $j$ ac.

\section{OKelye.}

the ffarme of Okelye in the occupacon of William Hellyer, of errable land in the ffieldes 160 ac., of wood gronnd lxxx ac.

John Knight, of errable land in the ffieldes 1 ac., of errable pasture ground lx ac, of medow ground ij ac., of wood ground ij ac.

John Knight, of Tydgrove, of errable pasture ground lx ac.

John Knight for Wackeridge, of errable pasture ground $\mathrm{xx}$ ac.

William Smithe, of errable land in the ffieldes lx ac., of errable pasture ground $x x v i j$ ac., of wood ground $\mathrm{x}$ ac.

Stonye Hall, of errable land in the ffieldes $x \times x$ ac., of errable pasture ground xiiij ac., of wood ground iij ac.

Bollsoms $\ddagger$ in the occupacon of Thomas Wareham, of errable pasture ground 160 ac., of wood ground vj ac.

Pytt ground in the occupacon of Richard Ailiffe, of errable pasture lx ac., of wood ground iij ac.

Pytt ground in the occupacon of John Butler, of errable pasture ground $\mathrm{lx}$ ac., of wood ground vj ac.

- Ffrowde. This surname of the eminent historian of onr own day is a very uncommon one in this district.

$\dagger$ Stantons is the well-known farm on the Newbury road so long occnpied in past days by the Flower family.

$\ddagger$ Bollsoms now called Bolthams. 
Spillman's ground in the handes of Payse, of errable pasture ground sviij ac., of wood ground iiij ac.

William Soper, of errable land in the ffieldes $\mathrm{lx}$ ac., of errable pasture ground $\mathrm{lx}$ ac., of wood ground iiij ac., of medow ground iiij ac.

\section{The Parsonage of Kingsclere.}

The parsonage of Kingsclere in the occupacon of Stephen Knight," of errable land in the ffieldes xl., of errable pasture ground ij ac., of modow ground iij ac., of wood ground $\mathrm{v}$ ac.

The tything of the Parsonage of Kingsclerr.

William Hunte, of errable land in all places of the ffieldes xxx ac., of pasture ground $\mathrm{xxxv}$ ac., of mead ground $\mathbf{v}$ ac., of wood ground iiij ac.

John Bacheler, of Pleastrow, $\dagger$ of errable pasture ground, $\mathrm{v}$ ac.

Tristam Coxheade, of errable land in the ffieldes iij ac., of medow ground iij ac.

Thomas Pettye, of errable land in the ffieldes xij a., of errable pasture ground ij ac.

John Chamberlain, of errable land in the ffieldes viij ac.

Peeter Knight, of errable land in the ffieldes xv ac.

Henry Smythe, for the land in the occupation of John Hinwood, of errable land in the ffieldes vj ac., of errable pasture ground ij ac.

Suma of Acres within the manor of Kingsclere by estimation at the tyme of the composition : of errable in the ffieldes, errable pasture, pasturc, meadowe, and woodes : totall

\begin{tabular}{|c|c|}
\hline $\begin{array}{l}\text { his division rated as } \\
\text { ppereth in foll. } 13,14 \text {, } \\
5,16 \text {, of this book } \\
\text { ow the particulars } \\
\text { ere then layd in } \\
\text { uery parishe at - }\end{array}$ & $\begin{array}{l}\text { xv qrters wheat. } \\
\text { ix lnmbes, price } 36 \text { s. } \\
\text { vij geese. } \\
\text { xj hennes. } \\
\text { vij Capons. } \\
\text { xix pullets. }\end{array}$ \\
\hline
\end{tabular}

- For note on the Knight family, see Highclere.

+ Now Plastow Green. 
The hundred of OuERTon, 1575.

Bradlye.

Imprimis the gleebe in the manurance ${ }^{*}$ of the parson xvij ac. err.

Itm he holdeth by Copye $x l$ ac., errable et valet pr ann., $\mathrm{xx}$ li.

FIRMARIU' + IBID.

Itm in errable xij yeard land, 360 ac., in pasture 220 ac., in woode ground 140 ac.

TENENTES IBID.

William ffinden i yard land - $\quad 30$ ac.

George Pryor, i yard land - - 30 ac.

Andrew Adames - $\quad$ - $\quad$ - $\quad$ xxij ac.

John Newman - $\quad$ - $\quad$ - $\quad$ - $\quad$ xxiij ac.

Eliz. Camis, di yeard land - - - $\quad$ - $\quad$ xv ac.

Thomas fforder $\ddagger \quad-\quad-\quad$ - $\quad$ vij ac. di.

The Parsonage of Cold Waltham.

In the manurance of the parson in glebe iiij yeard land Errab.

In pasture $\mathrm{x}$ ac., in wood ground iij ac., et valet pran £l.

FFIRMARIU' IBID.

In the manurance of James Rumboll $\S$ of errable xiiij yeard land 420 ac., in pasture $x l$ ac., in wood ground 70 ac.

* Manurance, i.e. in the occupation.

$\dagger$ ffirmarias, i.e., the farmer, tenant, or occupier of the manor lands. The rights and privileges of a manor were leased out from time to time to firmarii or land farmers as they were termed, acting in the name and ander the authority of the owners, shortly, they held the estate ad firmam or on farm.

$\ddagger$ Thomas fforder. This is the name of a family which has long held a prominent and honourable position in the city of Winchester.

$\S$ The very numerons and extensive family of Rumboll or Rambold held very considerable property here in the days of "Good Queen Bess," and has ever since been connected by the possession of estates in this neighbonrhood. Preston House, Preston Candover, the seat of the Rumbold family, was formerly the residence of the late Chas. Edmund Rombold, Esq., M.P. for Great Yarmonth. It has been pointed out to as by the Rev. Sumner Wilson, M.A., Vicar of Preston Candover, that there were before 1711, sixty-two small portions of land in that parish, ranging from below an acre to abont tive or six acres, called "Marsh Plots," or "Mersh Plots," the owners of which paid to the Churchwardens op to the above date one penny the Mersh plot. The payment was then lost. The vicar observes that the position of the Marsh plots here seems to point to an earlier arrangement than would arise from any large occapation of common lands-more probably to a lime when the smaller tenants holding ander lords of various manors had small plots of land for their own houses and home gardens. The Vicar receives for these lands only both small and great tithes. 'There is a similar castom in Surrey in the parish of Westbourne, there called Muse plots. 
TENENTES IBID EPISC. *

John Twine, $\dagger$ errab. $\mathbf{v}$ yeard land

250 ac., in pasture $\mathrm{xxx}$ ac.

Edward Bigges, ij yeard land - $\quad$ - $\quad \mathrm{k}$ ac.

Rowland Gedge, ij yeard land - - lx ac.

James Lambold, ij yeard land - - $\mathrm{k}$ ac.

Gilbert Cobb, ij yeard land - - lx ac.

Maude Siluer, ij yeard land - - $1 x$ ac.

John Bigges, ij yeard land - - $\mathrm{lx}$ ac.

Richard Brigilton ij yeard land - - $\quad \mathrm{lx}$ ac.

Thomas Lambold, iij yeard land - - l lxxxx ac.

Clapshew Vidua, iiij yeard land - $\quad$ - 120 ac.

John Woodman, one yeard land - $\mathrm{xxx}$ ac.

John Biggis, junr., one yeard laud - $\quad$ xxv ac.

William Searle, one yeard land - - $\quad$ xxx ac.

Robert Hughes, one yeard land - _ $\quad$ xxx ac.

Mawde Wareham, vid., one yeard land $\mathrm{xxx}$ ac.

Wood in Comon to the tenantes there - lxij ac.

The Parsonage of AsHe.

Itm in gleebe, one yeard land $\mathrm{xxx}$ ac., in medow ij ac., et valet $\mathrm{pr}$ an. $\mathrm{x} \nabla \mathrm{j}$ li.

FFIRMARIU' IBID.

In the manurance of Richard Pile, gent., $\ddagger$ of errable, xiiij yard land 420 ac., of pasture lxxx ac., of medow $\mathrm{xx}$ ac., in pasture for foulding shcep 200 ac., in wood ground 116 ac.

The Parsonage of Deane.

In glebe $\mathrm{ij}$ yeard land $\mathrm{l} x$ ac., in medow ij ac., et valet $\mathrm{pr}$ an. $\mathrm{xx}$ li.

Tenentes rbid.

William Rogers, errable iij yeard land 90 ac., and in seucrall pasture xvij ac., in medow iij ac.

John Basse, ij yard land lx ac.

William Small, 1 yard land $\mathrm{xxx}$ ac.

- The Bishops of Winchester are still lords of the Manor of Cold or North Waltham.

+ John Twine or Twyne. A meniber of the family of Twyne, of Longparish and Bullington, in the neighbourhood. He was long possessed of Ashe farm. John 'Twyne, the antiguary, born at Bullington, was great-great grandson of Sir Bryan 'Twyne, of Lougyarish. Bryan Twine, the Oxford antiquary, was grandson of John Twine before mentioned.

$t$ Of the fanily of Pile, baronets, of Compton Beauchamp, and Oakash, in the parish of Chaddleworth, Berks, and Axford, Ramsbury, Wilts. 
Richard Small, 1 yard land and $\frac{3}{4}$, xliij ac.

Thomas Harris, 1 yard land $\mathrm{xxx}$ ac.

Richard Winckworthe, ${ }^{*}$ ij yard land $\mathrm{lx}$ ac.

William Roneger, $\dagger$ di yard land $\mathrm{xv}$ ac.

William Butler, di yard land $x v$ ac.

William Parsons, 1 yard land xxx ac., in pasture iij ac., in Comon of pasture for folding sheep lvwv ac.

In wood ground in the handes of Rich. flines, Armig. 150 ac.

NUtSell, $\ddagger$ FFirmariu' ibid.

In the manurance of Roger Hunte, in errable 6 yard land 180 ac., in pasture 60 ac., in medow $\mathrm{v}$ ac., in pasture for foulding sheepe 140 ac., and the Lordes of the Manor hould in wood ground xlv ac.

Tenentes ibid (Polhampton).

William Hunte, in errable iij yard land 90 ac. John Trewloue, in errable iij yard land 90 ac. James Browne, in errable iij yard land 90 ac. Richard Edmonds, in errable ij yard land 60 ac. Margery Berry, in errable ij yard land 60 ac. George Knight, in errable ij yard land 60 ac. Edmond Goodalle, in errable ij yard land 60 ac. George Olding, i yard land - - $\quad \mathrm{xxx}$ ac. William Ailiffe, $\mathrm{j}$ yard land - - $\mathrm{xxx}$ ac. It $\mathrm{t}^{\mathrm{m}}$ seuerall pasture to the same tenants $200 \mathrm{ac}$. I $t^{m}$ wood ground to them belonginge - 50 ac.

* Winckworth is the name of a good old yeoman family which for more than three centuries has been continued in North Hants withont intermission, but varying frequently as to the mode in which it is spelt, as Wentworth, and other forms.

+ William Roneger. This name is spelt most variously thas: Renngar, Reniger, Raungire, Runneger, Runigar, Runnygar, Runniger, and as in this place Roneger. The name of Peter Ranngire occurs in a grant by William Brocas, of Beaurepaire, 5 Hen. v. 1417. John Runniger was a warden of the Holy Ghost Chapel, Basingstoke, 1556-7. His daughter Elizabeth was wife to Peter Cobb, of Northington, son to Thomas Cobb, of Swarreton, by his wife Agnes, danghter to John Hunt. The Rnnnigers are not without note in the annals of Hanpshire. One of their number was the celebrated Michael Runniger, Rector of Crawley, 1560, and Archdeacon of Winchester. Elizabeth, danghter to Sir George Paulet of Crondall, by his second wife Barbara, was married first to one Reniger, of Basingstoke, and afterwards to Walter Lambert. Her sister Mabel was wife first to Thomas Chandler, secondly to Roger Corham. Her brother was Sir Hambden Panlet, whose danghter Elizabeth was married to Francis Donce. (See note to Stoake). The nuid servant of Madame Blunden, of chap-book fame was one Anne Runniger.

$\ddagger$ Or Nutley. 


\section{QUIDHAMTON FFIRMARIU' IBID.}

In the manurance of William Denbye, of errable $200 \mathrm{ac}$.

In pasture 80 ac., in medow $x$ ac., in wood ground 44 ac.

\section{Capelila' ibid.}

In the manurance of Richard ffisher, gent., $\operatorname{xxx}$ ac., et valet pr. an. vli. and p. li.

In the manurance of ffrancis Palmes, gent., " errable $\nabla$ yard land 140 ac., in pasture $\mathrm{xx}$ ac.

Allso in Ouerton, of pasture $\mathbf{x}$ ac., in medow vij ac., and of errable there vij ac.

William Hunte, of errable iiij yard land 120 ac., in medow iij ac. Itm comon of pasture to the said Denbye, Palmes, Hunte, and the Chappell, + in the south side and north side 250 ac.

\section{The Parsonage of Ouerton.}

In the manurance of Henry ffrancis, gent., $\ddagger$ in glebe vj, yardo lande 180 ac.

In the manurance of the said Henry, viij yard land 240 ac., viz., Jordaynes ij, yard land, kerbyes ij, yard land, durbors $\mathrm{j}$ yard land, John ffrancklin iij yard land.

Itm in medow viij ac., in wood to the same $\mathrm{ij}$ ac., et valet pr. an. 80 li.

- Of the ancient family of Palmes, of Naborne, co. York. The Francis Palmes here mentioned, of Overton, was high sheriff of Hants in 1601, when he received Queen Elizabeth and her court on Silchester Heath, at the border of the country, and condacted the royal party to Basing Honse, then the princely seat of the Marquis of Winchester, where her majesty remained thirteen days. The queen on leaving Basing made ten knichts, amongst them being Francis Palmes the sheriff, and Hambden Paulet. Francis Palmes and Hambden Panlet were nearly allied through their wives, Mary and Anne, the daughters and co-heiresses of Stephen Hodnell, chamberlain to Queen Mary, by Margaret his wife, danghter to Thomas Atkyns, Esq. After Stephen's death Margaret becaune the wife of Sir Richard Lewkenor. Mary, wife to Francis Palmes died 25 March, 1595, aged 37. This Francis Palmes was heir to Francis Corby or Corbet. It is said that on the occasion of the visit of Queen Elizabeth to Basing as on other progresses, there was an immense company of scallions and other inferior officers of the royal household in her train, who were by the common people jocularly termed the black guard; to which various allusions occur in old writers. In all appearance, the term of reproach which has become so common in modern times, dates its origin from this popalar jest.

+ There was at this time a Free Chapel attached to the manor of Quidhampton.

\$ The name of Henry Francis occurs in the "Narratives of the Reforma. tion," Cam. Soc. in a dialogne between (iardiner, Bishop of Winchester and John Philpot, the martyr, son of Sir Peter Philpot, of Compton, near Winchester. May this not have been the Henry Francis, who at this time held the parsonage of $\mathrm{O}$ verton ander the Bishop of Winchester? 
FFIRMARIU' IBID.

In the manurance of John ffisher, gent., ${ }^{*}$ in errable xviij yard land 540 ac., in pasture 80 ac., in medow viij ac., in pasture for foulding sheep 400 ac., in wood ground 60 ac. Episc. Wint, te.

Southanton.

Richard Denbye, errable ij yard land 75 ac., in seuerall pasture 20 ac. Rose ffincklye 1 yard land $x x x$ ac.,

John Gedge, errable iij yard land 90 ac.

Itm in pasture iij ac.

Joane Horne di $\uparrow$ yard land $\mathrm{xv}$ ac.

Thomas Goodall di yard land errable xv ac.

Nicholas Harte i yard land xxx ac.

Medow ij ac., wood ij ac.

Richard Palmes, gent., $\ddagger$ iij yard land 90 ac., medow ij ac., wood ij ac. Philip Nash $j$ yard land di xlv ac.

John ffrancklin, sen., j yard land di xlv. ac.

$\mathrm{Itm}$ in medow ij ac.

$\mathrm{Itm}_{\mathrm{m}}$ in comon of pasture for foulding to the parson viz, Henry ffrancis, gent. and tenants there, 300 ac.

NoRTHINTON FFIRMARIU' IBID.

Rumboll Wadlow, errable xiij yard land 410 ac., in pasture xv ac., in medow viij ac., in pasture for folding sheep 300 ac.

LAVERSTOCKE.

The parsonage of Laverstocke in the manurance of the parson there in gleebe iij yard land 90 ac., et valet pr. an. $\mathrm{xx} \mathrm{li. \S}$

\section{FFIRMARIU' IBID.}

In the manurance of Gregory Mathew, errable xij yard land 360 ac., in pasture xl ac., in medow viij ac., in pasture for foulding sheep 440 ac., in wood ground 60 ac., wch Mr. fforteseue houldeth.

* The Fishers were allied with some of the best known families in Hampshire. Margery, daughter to James Fisher, of Chilton Candover, was third wife to William Wallop, of Weld, whose sister Rose was married to Sir Walter Lambert, whose half-brothers were Sir Henry and Richard Wallop, and whose father Sir Oliver, of Farley, brother to Sir John Wallop, K.G., was son to Stephen Wallop, by his wife the danghter of Edmund Ashley, of Winborne St. Giles.

$\dagger$ di, or dim., a Latin abbreviation for half.

f Richard Palmes was brother to Francis Palmes, sheriff of Hants, 1601. See note to Quidhampton.

$\S$ Richard Lambert, in 1651, conveyed the manor and rectory of Laverstoke to Sir John Trott, created a baronet in 1660. He niarried Elizabeth, daughter and co-heir of Sir Edmund Wright, Lord Mayor of London, and had by her, who married 2ndly, Lord James Russell, 6th son of William, Duke of Bedford, an only danghter, Catharine, who married Sir Hugh Stukely, Bart., of Hinton, Hants. 
Hundred of Ouertos, continued.

Tenentes in Lauerstocke.

Thomas Dauye, errable i, yard land dim. - xlv ac.

Christian Mason, errab. j, yard land dim. - xlv ac.

Gregory Mathew, i yard land dim. - - xlv ac.

Edward Hayward, i yard land dim. - - - xlv ac.

Thomas Penton, i yard land and vij ac. - exxrij ac.

Henry Sutton, ij yard land - - - lx ac.

Richard Toply, di. yard land - - - xv ac.

Guye Michill, errab. - - - - - xxij ac.

Walter Cuffly, di. yard land errab. - - $\quad$ xv ac.

William Luke, one yard land di. - - - xlv ac.

John Gilbert - - - - - - xviij ac.

Tadleye.

In the manurance of George Ludlowe, Esquire, ${ }^{*}$ pasture, - - - - - 200 ac. In medow - - - - - - $\mathrm{xx} \mathrm{ac.}$

William Apleton, in pasture - - - xlv ac.

Reynold Haniton $\dagger$ in pasture 160 ac., in medow xij ac.

Henry Prior, junr., in pasture - - - $\mathrm{xl}$ ac.

Richard Coles, in pasture - - _ - $\mathrm{xxx}$ ac.

Richard Shoreland, in pasture - - - $\mathrm{xxx}$ a.

Robert Still, in pasturo - - - $\quad$ - $\operatorname{xxx}$ ac.

In medow - - - - - - - iiij ac.

Thomas Prior, in pasture - - - - $\mathbf{x x}$ ac.

Henry Prior, sen., in pasture - - - $\mathrm{xxx}$ ac.

Richard Sheffilde, in pasture - - - $\mathbf{x x x}$ ac.

Widow Lawnclett $\ddagger$ in pasture - - - $\mathrm{xvj}$ ac.

Ralfe Pilgrim, in pasture - - - - $\mathbf{x x}$ ac.

* George Ludlow, of Monks'Sherborne, son of Willian Ludlow, of Tadley Place. High Sheriff of Wilts, 1567. Tadley Place, the ancient seat of the Ladlows, is now a ruinated farm-house, bat retains many evidences of its former importance. An accoant of the Parish of Tadley and the Ladlows will be fonnil in the Transactions of the Nerobury District Field Club, vol. iv. pp. 139-164.

$\dagger$ Reynold or Reginald Haniton. This family of Hanington lived at Tadley for many generations. Margaret, daughter of the Reynold Hanington here mentioned, married John Bye, gent., of Basingatoke, whose surviving son Joln Bje, of Brsingstoke and Heckfield, erected a monument in Bramley Church to his ancle Reginald Hanington, gent., who died a bachelor, 21 May, 1602, aged 72.

See note on the name of Lawuclett, Launcelet or Launcelevees, ander Edmonstrop Launcelewill. 
Richard Wither, in medow - - - - vi ac.

Hugh Duffin, in pasture - - - - xij ac.

Itm comon of pasture - $\quad$ - $\quad$ - 500 ac.

Borough of Ouerton.

John Douce, sen., ${ }^{*}$ one yard land errable

xxx ac. in medow iij ac.

John Magwicke, $†$ di. yard land - - - $\quad$ xv ac.

William Lancaster, one yard land - _ $\quad$ xxx ac.

$\left.\begin{array}{l}\text { ffrancis Palmes } \\ \text { William Ayliffe }\end{array}\right\}$ Constables.

The Hundred of Evenger, 1575.

Whiтchurch.

John Clarke holdeth the manor of Whitchurch, in ffarme and hath by estimacon, $x$ yard land, whereof in pasture $\mathrm{xl}$ ac., in medow $\mathrm{xx}$ ac., in wood iiij ac., the rest in errable and is charged with the payment of wheat, vij buh.

Richard Brooke, $\ddagger$ holdeth the parsonage there in ffarme and hath in gleebe land, iij yard land, whereof in pasture viij ac., the rest in errable. Also the same Richard hath within the pishe of Whitchurch, ijj yard land whereof $\mathrm{xx}$ ac. is wood ground, the the reste errable and is charged with the payment of wheat, vj buh.

* In a cause heard in the Conrt of Star Chamber, 7 Jac. I., 1609, between John Patye, of Chieveley, Berks, Yeoman, plaintiff, and Francis Palmes, of Overton, gent., Andrew Holdip, gent., and John Dowse, of Overton, gent., defendants, the names of the following persons appear in the depositions:Simon Holdip, Parson of Ashe and Deane, Richard Money, of East Woodhay, gent., William Mayne, of Ashe, yeoman, and George Ayliffe, of Southington, yeonian, Thomas Twyne, of Overton, yeoman, and Richard Pococke, of Shawcum-Domnington, yeoman. The depositions were taken at the "Lyon "Inn, Newbury, before Nicholas Fuller, Esq., counsellor of Gray's Inn, who lived at the old mansion of Chamberhouse, in the parish of Thatchaw, in the church of which place he is commemorated by a handsome monument.

$\dagger$ The Madgwicks were long settled at Dunimer. Henry Madgwick of this place, born in 1592, was a scholar and fellow of New College, B.C.L., and Rector of Allington, Wilts; and another Henry Madgwick, L.L.B., was admitted Fellow of Winchester College, 11 August, 1618.

$\ddagger$ There is a brass now affixed on the wall at the end of the south aisle of Whitchurch Church with effigies of this Richard Brooke and his wife, with the following quaint inscription :-

Pietatis opus.

This graue of griefe hath swallowed up with wide and open mouth,

The bodie of good Kichard Brooke, of Whitchurch, Hampton south,

And Elizabeth his wedded wife twice twentie yeares and one

Sweete Jesus hath their soules in heaven, $\mathrm{J}^{\mathrm{e}}$ ground, flesh, skin, and bone. 
COMPUSITION.

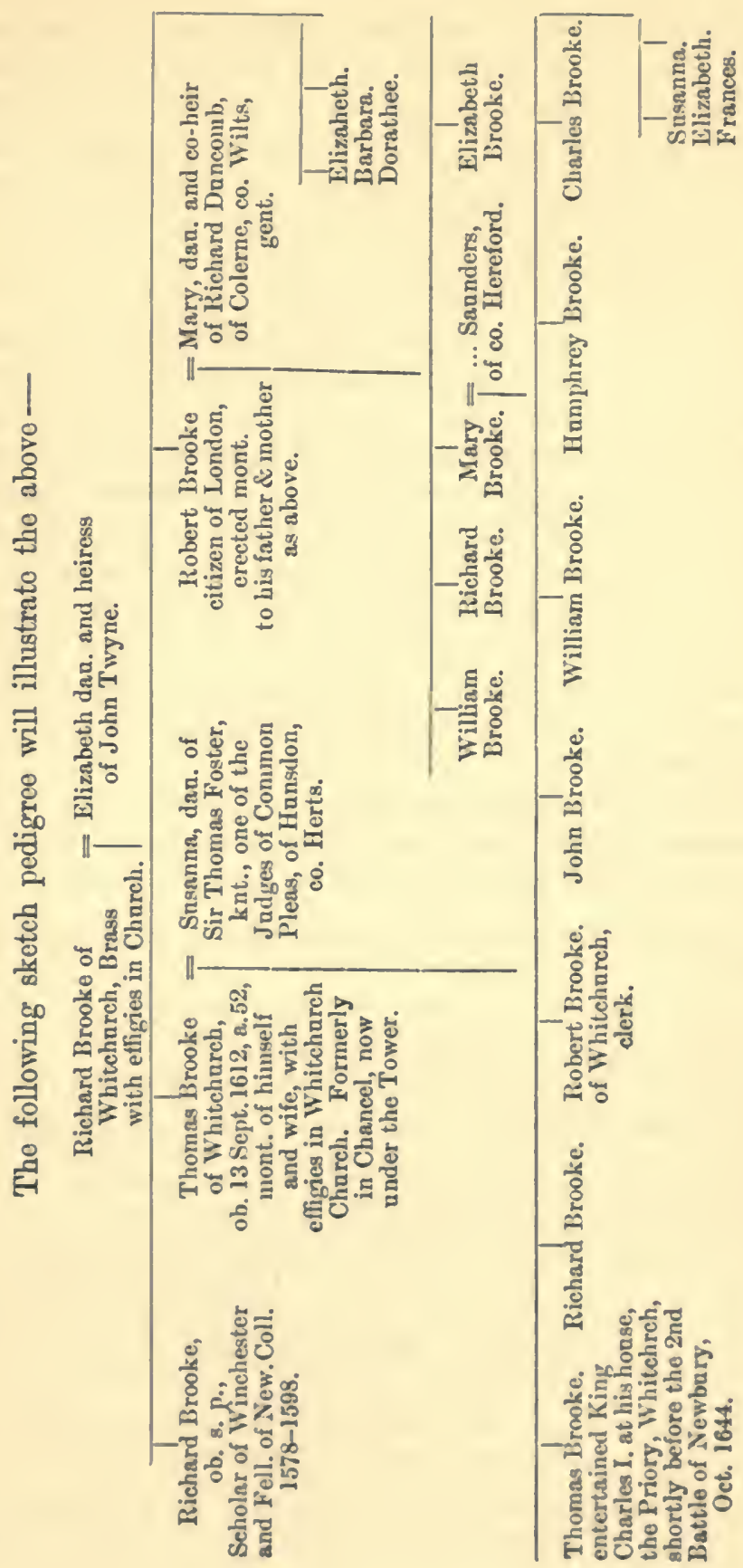


Simon Reeue holdeth Mr. Maton's ffarme wch is ij yard lande, whereof in pasture viij ac., in medow viij ac., in woode xvj ac., the rest in errable, all wch land is now in the tenure of Thomas Perry, John Spencer, William Brexton, Thomas Kidgill, Winifred Poynter, John Harison, and Nicholas Heywood, * and is charged with the payment of wheat, $\mathrm{vj}$ buh.

Robert Cooper holdeth iij yard land whereof $\mathrm{xx}$ ac. is woode and the rest errable and charged with wheate, ij buh.

Nicholas ffoster holdeth iij yard land, and a Cossett whereof in medow iiij ac., in pasture $\mathrm{ij}$ ac., the rest in errable, and is charged with wheat, ij buh.

Thomas Bowyett, iij yard land whereof in medow ii ac., in pasture ij ac., th rest in errable, and is charged with wheat ij bus.

Winifred Poynter hath ij yarde and a halfe of land, and $\mathrm{xx}$ ac., of ffree land, whereof in pasture iij ac., in medow viij ac., the reste in errable, and is charged with the payment of ij buh.

Richard Beanes hath ij yard land viz xl ac., whereof in pasture iiij ac., in medow iiij ac., and is charged with wheat $\mathrm{j}$ buh.

John Howse, $\mathrm{j}$ yard land and a Cossett, whereof in medow ij ac., in pasture ij ac.

Richard Buttler hath iij ac. of ffreeland in errable.

Edmond Cooper hath ix ac. of ffreeland in errable.

Thomas Siluer hath $\mathrm{j}$ Cossett land, whereof ij ac., medowe.

* These names are found at a very early date at Whitchurch and the neighbourhood.

In Januarie (worn with age) daie sirteenth died her

ffrom Christ fall fifteene hundred yeares, and more by nearly three

But death his twist of life in Maie daie twentieth did nntwine,

ffrom Christ full fifteene handred yeares and more by ninetie nine.

They left behinde them well to line and growne to good degree

Ffirst, Richard, Thomas, Robert Brooke, the youngest of the three.

Elizabeth and Barbara then Dorathee the last.

All six the knot of natures lone and kindness keeping fast.

This tombstone with the plate between thas graven fair and large

Did Robert Brooke the youngest sonne make of his proper charge.

A citizen of London state by faithfall service free.

Of Marchante greate adventurers and brother chosen is hee.

And of the Indian Companie (come gaine or losse) a son.

And of the Goldsmiths linerie-All these God's gifte to him :

This monument of memorie in love performed hee.

December twentie one from Christ sixteene handred and three.

Anno Domini, 1603.

Laus Deo.

Arms. Quarterly, 1 and 4 checky, or and azare, on a bend gules a lion passent or [Brooke]; 2 and 3, Argent a fess embattled sable, in chief two estoils of the second [Twyne]. 
Thomas Bunny, sen., j Cossett land* and ij ac. of ffree land whereof $j$ ac. of medow.

John Spencer, ij Cossett lands and ij ac. of frreeland, all errable.

Richard Penton, $x$ ac. of errable.

John Poynter, j Corsett land, errable and medow ij ac.

John Phillips, j Corsett land of errable.

Richard Poynter, ij Corsett landes and ij ac. of ffreeland.

William Quecne, $\mathrm{j}$ yard land whereof $\mathrm{j}$ ac. medow, the rest errable.

John Penton, $\mathbf{v}$ ac., of ffreeland crrable.

Robert Smith, j. Corsett land whereof $\mathrm{j}$ ac. pasture.

Thomas Reynoldes, iij Corsett landes whereof $\mathrm{j}$ ac. medow.

William Brixtonc, ij ac. of ffreeland errable.

$$
\left.\begin{array}{c}
\text { Suma of wheate in } \\
\text { Whitchurch. }
\end{array}\right\} \text { xxiij buh. }
$$

\section{Charlecott.}

Roger Rutter hath iij yard land and a Cossett whereof in wood iij ac., in medow ij ac., in pasture ij ac, the rest in crrable, and charged with the payment of wheat ij buh.

William Soper hath iij yard land whereof in wood iiij ac., in medow iij ac., in pasture $\mathrm{j}$ ac., and is charged with wheat $\mathrm{ij}$ buh. William Wadlow hath iiij yard land whercof in wood iij ac., in medow iij ac., in pasture $\mathrm{j}$ ac., and is charged with wheate $\mathrm{ij}$ buh.

$$
\text { Suma of wheat in Charlcott } \quad \text { j buh. }
$$

\section{Colmexlye. $\dagger$}

Mr. Richard Audlye $\ddagger$ holdeth the manor of Colhenly and hath by estimacon vij yard land whereof in wood $\mathrm{xx}$ ac., in pasture $\mathrm{xxx}$ ac., in medowe $\mathrm{vj}$ ac., the rest is errable and charged with wheate, iiij buh.

- Cossett or Cossett land. Small pieces of land of varying quantity, generally about 5 acres, held by a cottager, for which he paid a rent in money or produce as well as rendering some customary service. By the statate, 31 Elizabeth, no man might build a cottage unless he lay four acres of land thereto, freehold and land of inheritance.

$t$ Colhenlye or Cold Henley. Probnbly a corrupation of Col. Henley, the prefix indicative of the colonial occupation of the Romans, and the suffix from Hen legh the high legh a true description of the table land which is to be seen in such large tracts at the top of the downs in this locality. The Free Chapel of Cold Henley is mentioned in a compotu of the year 1526.

t Mr. Kichard Aadlye. The name of Audley does not appear as an established one in the county of Hants, and this gentleman seeus to have been related to Sir Joun Audley, who belonger to a Norfolk fanily of that name. and became connected with Hampshire by his wardship of the two daughters and heirs of William Brocas, of Beaurepairo-Anne, who married Sir George Warham, and Edith, married to Ralph Pexsall. 
John Lamden hath ij yard land and halfe wherof halfe yard land in wood, the wch his Lord holdeth from him, the reste is errable and barren.

$$
\text { Sum of wheat in Colhenly. } \quad \text { - } \quad \text { iiij buh. }
$$

FFREEFOLKE.

Mr. John Powlett, Mr. Walter Lambert, and Mr. Henry Norris* hould the manor of ffrefolke by estimacon viij yard land wherof in pasture $\mathrm{lx}$ ac., in medow $\mathrm{xx}$ ac., in wood l $\mathrm{xxx}$ ac., and the rest errable, charged with the payment of wheat viij buh.

Peter Cropp hath iiij yard lands wherof in wood $\mathrm{xx}$ ac., in pasture iij ac., in medow . . ., and is charged with wheate ij buh.

Thomas Clarke hath iij yard land wherof in wood v ac., in medow ij ac., and is charged with wheate $\mathrm{ij}$ buh.

Christian Mason hath iiij yard land wherof in medow $\mathrm{j}$ ac., and is charged with wheate ij buh.

Richard Cuffly holdeth iij yard land wherof in wood xiiij ac., in medow $\mathrm{j}$ ac., and is charged with wheat ij buh.

William Sutton holdeth iiij yard land and a Cossett wherof in wood $\mathrm{ij}$ ac., in medow $\mathrm{j}$ ac., and is charged with wheat $\mathrm{ij}$ buh.

Hewe Benham hath $\nabla$ yard land wherof in wood viij ac., in medowe $\mathrm{j}$ ac., and is charged with wheate $\mathrm{ij}$ buh.

* By his will of $4 \mathrm{Ang}$. 1503, Sir Reginald Bray gave the manors of Freefolk, East Woodhay, and Quidhanipton, to his nephew Richard Andrews and his wife Elizabeth with remainder to heirs male of John Bray. John Powlett, son of Richard Powlett, by his wife Elizabeth, danghter to Peter, the last of the Herriard Cowdreys, narried Catherine, danghter to Richard Andrews, of Freefolk and Laverstoke. Richard Androws died seized of Fryfolke South or Syferwast, with Laverstoke, and Chalgrove, co. Oxon. By partition deed of $17 \mathrm{Jnly,} \mathrm{1582,} \mathrm{Catherine,} \mathrm{widow} \mathrm{of} \mathrm{John} \mathrm{Powlett,} \mathrm{received} \mathrm{Freefolk} \mathrm{and}$ Chalgrove, and a rent of $£ 20$ charged on Freefolk. Catherine's sisters were Ursula married to Henry Norris, and Constance married to Richard Lambert, of Twyford, co. Hants, father to (Sir) Walter Lambert. A Richard Lambert, in 1651, conveyed Laverstoke to John Trot, who was made a baronet in 1660 . Henry Norris or Norreys, of the family of the Lords Norreys, of Rycote, was of Ockwells in the parish of Bray, co. Berks, and in the church there was formerly a brass commemorating Ursnla Andrews, danghter of Richard Andrews, of Freefolk, "wife of Henry Norreys, gent.," who died 18 Jnne, 1560. The ledger in which the brass was fixed was the ancient altar slab before the Reformation. Four of the consecration crosses remain at the angles. The stone now lies beneath the communion table. Oliver Lambert only son of the Walter Lambert above-mentioned by his first wife, Rose, dau. of Sir Oliver Wallop, kt., and sister to Sir Henry Wallop, kt., treasurer-of-war in Ireland, ancestors of the Earls of Portsmonth, was father to Oliver Lambert, knighted by the Earl of Essex at the sacking of Cadiz, in 1596, and in 1601 was appointed Governor of Connanght. He was created Lord Lambart, Baron of Cavan, 17 Feb., 1617, and by his wife, Hester, dan. of Sir William Fleetwood, of Carrington Manor, co. Beds., kt., was ancestor of the Earls of Cavan. 
Andrew Roaffe ${ }^{*}$ hath $\mathrm{v}$ yard land wherof $\mathrm{j}$ ac., medow and the reste errable, and is charged with wheato ij buh.

Joane Siluer hath $\nabla j$ yard land and dim., wherof in wood vij ac., in medow $\mathrm{j}$ ac., in pasture $\mathrm{j}$ ac., and is charged with wheate iij buh.

Thomas Webbe, ij yarde landes errable.

Robert and Henry Beenham ij yard lands errable.

Sum of Wheate in ffreefolke - iij qrters. $j$ buh.

HUSBORNE.

The Lady Oxenbregg $\dagger$ for the manor of husborne by estimacon xiij yard land wherof in pasture lxx ac., in medow 1 ac., in wood beside the ffranchises $\operatorname{lxx}$ ac., the rest errable, and is charged with the payment of wheate viij buh.

William Milles hath iij yard land wherof in pasture $\mathrm{xx}$ ac., in medow xv ac., and charged with the payment of wheat ij buh.

Richard Kingsmill, Esqr., $\ddagger$ hath vj yard land, wherof in medow $\mathbf{x x x}$ ac., in pasture $\mathrm{v}$ ac., in wood $\mathrm{v}$ ac., the rest errable and charged with wheat iij buh.

Swithine White hath $\mathrm{v}$ yard land wherof in medow ij ac., in pasture ij ac., and is charged with wheate ij buh.

William Siluester $§$ hath ij yard land wherof in medow $\mathrm{j}$ ac., in pasture $\mathrm{j}$ ac., and is charged with wheate $\mathrm{j}$ buh.

Thomas ffisher hath ij yard land wherof in pasture $i j$ ac., and is charged with wheate $\mathrm{j}$ buh.

- The Roaffes or Roffes were Protestant émigrés.

t Lady Oxenbridge. Alice, one of the danghters and heirs of Thomas Fogg, of Asb, Kent, relict of Edward Scot, second son of Sir William Scot, knt., married 2ndly to Sir Robert Oxenbridge, of Harstbonrne, who died in 1574 . Lady Oxenbridge died circa 1583.

$\ddagger$ Richard Kingsmill, Esq. Of Highclere, Sarveyor of the Conrt of Wards. His lst wife was Alice, sister and heiress of Richard Fnnconer, of Hurstbonrne Priors, by whou he had one danghter, Constance, who married Sir Thomas Lacy, of Charlcote, co. Warvick, son and heir of Slakespeare's Sir 'Thomas Lncy. He died in 1600, and was buried in the old charch of Highelere. His second son Richard, was created a baronet, 11 March, 1617-18. Richard's eldest son, Kingruill Lney, of Fnocombe married Theophila, danghter to I.ord Berkeley, who after his denth, married (despite the difference in their creeds), Robert Nelson, of the "Fasts aud Festivals." Berkeley, third and last baronet, son to Kingsmill and 'Theophila Lucy, died 19 Nov., 1759. Ilis wife was Catherine, daughter of Charles Cotton, of Beresford, well-known as the nuthor of the "Wonders of the Peak," and for his part in the "Complete Angler."

$\S$ The nane of Sylvester is afforded to a list of Charch Goods, teup, Edw. VI. 
John Becham hath ij yard land and halfe wherof in medow $j$ ac., in pasture $\mathrm{ij}$ ac., and is charged with wheate $\mathrm{j}$ buh.

Richard gosslinges hath ij yard land wherof in medow $v$ ac., and is charged with wheate $\mathrm{j}$ buh.

William Issarne hath $\mathrm{j}$ yard land wherof in medow $\mathrm{j}$ ac., in pasture $\mathrm{j}$ ac.

Christian Willkins hath half-yard land in errable $j$ ac. in pasture.

John Cooper hath ij yard land wherof in medow $\mathrm{j}$ ac., in pasture $\mathrm{j}$ ac., and charged with wheate $\mathrm{j}$ buh.

Sum of wheate in husborne - ij qrs. $\mathrm{v}$ buh.

\section{HUSBORNE.}

Alice Siluester, $\mathbf{j}$ ac. medow and vij errable.

Anthony Heath, $j$ yard land wherof in medow $j$ ac.

Morice Holland, $j$ yard land wherof $j$ ac. pasture.

John Brooker, dim. yard land wherof $j$ ac. pasture.

William Godden, $\mathrm{j}$ yard land halfe wherof in medow $\mathrm{j}$ ac.

John Laske, $j$ yard laud wherof in pasture $j$ ac.

Christian Newell, $\mathrm{j}$ yard land dim. wherof in pasture $\mathrm{j}$ ac.

Richard Blanchard, $j$ yard land wherof in pasture $j$ ac.

Mathew Gawen,* dim. yard land wherof $\mathrm{j}$ ac. pasture.

Richard Blanchard, jun., one yard land wherof in medow ij ac.

Christian Newell, $\mathrm{j}$ yard land wherof in medow and pasture ij ac.

John Brooker, $\mathrm{j}$ yard land wherof in medow $\mathrm{j}$ ac., in pasture $\mathrm{j}$ ac.

George Penton, $\mathbf{j}$ yard land wherof in medow $\mathrm{ij}$ ac., in pasture $\mathrm{j}$ ac.

John Billett, dim. yard land wherof in pasture and medow ij ac.

John Waterman, dim. yard land wherof in pasture and medow ij ac.

Elizabeth Adams, $j$ ac. medow and vij ac. errable.

Nicholas Hunte, dim. yard land errable.

Thomas Edwards and Robert Hedges, ech of them $\mathrm{j}$ yard land errable.

* Of the Gawens of Norrington, in the Vale of Chalk, Wilts. $-\mathrm{a}$ family traced by Aubrey to so high and noble a sonrce as King Arthar. Norrington was their seat from 1377 to 1658 , when it passed to the Windhams. 
The Tythng of St. Mary-Bourne.

Jeffery Poore, ${ }^{*}$ hath $\mathrm{v}$ yard land wherof in medow $\mathrm{v}$ ao. in pasture ij ac., in wood $v j$ ac., the reste errable, and is charged with wheate iij buh.

Simon Cooper hath ij yard land wherof in medow $\mathrm{j}$ a., and charged with wheate $\mathrm{j}$ buh.

William Laske hath $\mathrm{j}$ yard land wherof in medow $\mathrm{j}$ ac., in pasture $\mathrm{j}$ ac., in wood $\mathrm{j}$ ac., and is charged with wheate $\mathrm{j}$ buh.

John Braye + hath $\nabla$ yard land wherof ij yard land is in Stoke and in pasture iij ac., in medow $\mathrm{v}$ ac., in wood iiij ao., and the said John Braye hath more dim. yard land of Wigmores in all charged with wheat iij buh.

Richard Underwood hath ij yard land wherof in medow $\mathrm{j}$ ac., in wood vj ac., and is charged with wheat $j$ buh.

John Braye, by the Church, hath ij yard land wherof in medow ij ac., in wood ij ac., and is charged with wheat $\mathrm{j}$ buh.

John Brexstone $\ddagger$ hath iiij yard land wherof in medow xij ac., in pasture ij ac., in wood ij ac., charged with wheat iij buh.

Mr. Roger Corham $\S$ holdeth the parsonage in ffarme, and hath dim. yard land in errable, and he holdeth more $\mathrm{v}$ yard land of my Lady Oxenbregg wherof in medow viij ac., in pasture ij ac., in wood vij ac., and is charged with the payment of wheate for the whole ij quarters.

Hewe Laske hath ij yard land errable.

Bartholomew Smith j yard land errable.

Hewe Laske hath ij yard land errable.

Bartholomew Smith j yard land errable.

John Smith ij yard land wherof i ac. medow.

* The Poores extended to many villages in North Hampshire. John and Thomas Poore were living at St. Mary Bourne before 1545; where they remained from generation to generation nntil recent tinses. Some of this old yeoman stock occupied a good position in Newbury in the 16th and 17th centuries; and several nembers of the family went from Hampshire and Wiltshire to New England about the year 1635, and their descendants are promiment citizens of Newbary and other towns in Massachusetts at the present day. The Poores of Newbury (England) were connected by marriage with the old Wiltshire family of Morse, also an hononred name in the Annals of New England. In the parish charch of St. Mary Bourne an inscription records that the Church clock was pat apat the expense of Mr. Richard Poore, a native of the parish, in the year 1820 .

$t$ The Brays were connected with this parish previous to 1545 .

t The nanie of Brexton appears in the subsidy of 34 Hen. VIII.

$\$$ Mr. Roger Corham. A prominent Winchester citizen, and member of a Devonshire family. Joln Corhnm, of Ottery St. Mary, liad several sons, of whom the third, Roger, of Barton, co. Hanla, married Isabell, daughter to Sir George Paulet or Powlett, of Crondall. They had several children, the eldest of them namel after his father Roger. 
- Thomas Bestocke hath iij yard land wherof in medow ij ac., and in pasture $\mathrm{j}$ ac., and is charged with the payment of wheat ij buh. Elizabeth Crooke hath iij yard land whereof in medow ij ac., in pasture ij ac., in wood iiij ac., and is charged with the payment of wheate ij buh.

Sum of wheat in St. Mary-bourne.

- iiij qrter. $\mathrm{j}$ buh.

\section{The Tything of StoAke.}

William Hayse holdeth vj yard land wherof in pasture viij ac., in medow vj ac., in wood $v$ ac., and is charged with the payment of wheate $v$ buh.

Richard Wigmore hath vj yard land wherof iiij yard land he houldeth of my Lady Oxenbregg, and ij yard land of the Deane of Windsor, and hath in pasture iij ac., in medow vj ac., in wood vj ac., and is charged with the payment of wheate iiij buh. William Elderwill hath iij yard land and dim., wherof in pasture ij ac., in medow $\mathrm{v}$ ac., in wood $\mathrm{vj}$ ac., and is charged with the payment of wheat ij buh.

George ffines* hath ij yard land and dim., and more dim. yard land of Bigges his land wherof in medow iij ac., in wood ij ac., and is charged with wheate $\mathrm{j}$ buh.

John Rumboll hath ij yard land and dim., wherof in medow ij ac., in wood iij ac., and is charged with wheat $\mathrm{j}$ buh.

George Rumbold hath ij yard land wherof in medow ij ac., in pasture $j$ ac., in wood $i j$ ac., and is charged with wheate $j$ buh. Thomas Dowse $\dagger$ hath $\mathrm{j}$ yard land dim., wherof in medow $\mathrm{ij}$ ac., in wood ij ac.

* Of the family of Fiennes, Lords Saye and Sele. They held several properties in North Hants. Sir Richard Fiennes, of Broughton Castle, Oxfordshire, who held the manor of Earlstone, in the parish of Burghclere, was great great-grandson of Margaret, wife of William, Lord Saye, daughter and heiress of William Wykeham, of Broughton. This was the great Elizabethanizer, of Broughton. He died 13 Aug., 1579. Sir Richard Fiennes, his son and heir, who was admitted to Winchester College, as founder's kin, in 1569, married (1) Constance, daughter of Sir William Kingsmill, of Sydmonton, and (2) Elizabeth, daughter and heir of Henry Coddingham. His son William, by his first wife, was created Viscount of Saye and Sele, 7 July, 1624. (See Note p. 58.)

$t$ 'Thomas Dowse. The family of Dowse or Douce was of consideration in Hampshire. Nicholas Douce, of Hurstbourne, was father of Richard Douce, of Moore Court, co. Hants, who married Alice, daughter of George Tutt, of that place. His son Richard Douce, of Moore Court, married Elizabeth, daughter of Thomas Paulet, of Melplash, co Dorset. Thomas Douce, of Broughton, brother of Richard, was father of Sir Francis Donce, of Broughton and Nether Wallop, who married Elizabeth, danghter of Hambden Paulet. From this branch of the family Francis Donce, the well-known antiquary, was descended. His ancestor, Sir Francis Douce, was Sheriff of Hampshire in the fourth year of Charles II. 
Bawden Leshe, $\mathrm{j}$ yard land and halfe wherof in medow ij ac., in wood ij ac.

William Woddard, $\mathrm{j}$ yard land wherof in medow $\mathrm{j}$ ac., in wood iiij ac.

George Bachelor, $\mathrm{j}$ yard land wherof in medow $\mathrm{j}$ ac., in wood iiij ac., and is his ffreeland.

Joane Hawkine hath xxiij ac. of land wherof $j$ ac. medow and $j$ ac. in pasture.

Robert dim. yard land errable.

Sum of wheate in Stoake - 1 qrter. vj buh.

\section{The Tythinge of WEEkE.}

Richard Hayse hath $\mathrm{v}$ yard land wherof $\mathrm{j}$ yard land liethe in Stoake, and hath in wood vij ac., the rest errable and charged with the payment of wheat iij buh.

Mr. Robert Oxenbregge * holdeth in Week iij yard land late Richard Watts and ij yard land late Thomas Elderwildes, and $\mathrm{j}$ yard land late hernes, and hath in wood vj ao., and is charged with the payment of wheat iij buh.

Richard Cooper hath iij yard land wherof in wood $\mathbf{v}$ ac., and is charged with the payment of wheat ij buh.

Eliz. Billett holdeth iij yard land wherof one yard land lyeth in Swampton, in all of wood ground iiij ac., and is charged with the payment of wheate ij buh.

Thomas Canon hath two yard land and dim. errable, and is charged with the payment of wheate $\mathrm{j}$ buh.

The Lady Oxenbregg holdeth in Weeke iij yard land of errable and sheepe pasture besides $\mathrm{lx}$ ac. of copis wood in the ffrmnchises. $\dagger$

- Robert Oxenbridge, Esq,, afterwards Sir Robert Oxenbridge, son of Sir Robert Oxenbridge, of Hurstbourne Priors, and Alice his wife. He married Barbara, daughter of Sir Thomas White, knt., of Soath Wanborough, co. Hants, Master of the Court of Requests. He died at Harstbourne, $22 \mathrm{Jan} .1591$. t "The franchises." Now written "Irenches," an exaumple of how local names become corrapted in coarse of time. Lady Osenbridge lived at Week or Wyke honse, now Upper Wike, at the same time her son Sir Robert lived at Hurstbonme Priors. The arms of the Oxenbridges are mentioned in 1861, as being displnyed on portions of the interior of the louse, but on a recent visit we found the whole place had been "sweyt, and garnished," not a restige of its former importance remaining beyond a stack of Jacobern chinneys, and an ancient lock on one of the attic doors. The situation of the house is very fine, but the graud view to the sonth is obsenred by the block of farm buildings inmediately in front. The farm is now occupied by Mr. Eylex, belonging to an old family mentioned by Dr. Stevens in his "Hist. of St. Mary Bourne," as an ancient stock in the neighbourhood. 
84 A ROYAL PURVEYANCE IN THE ELIZABETHAN AGE.

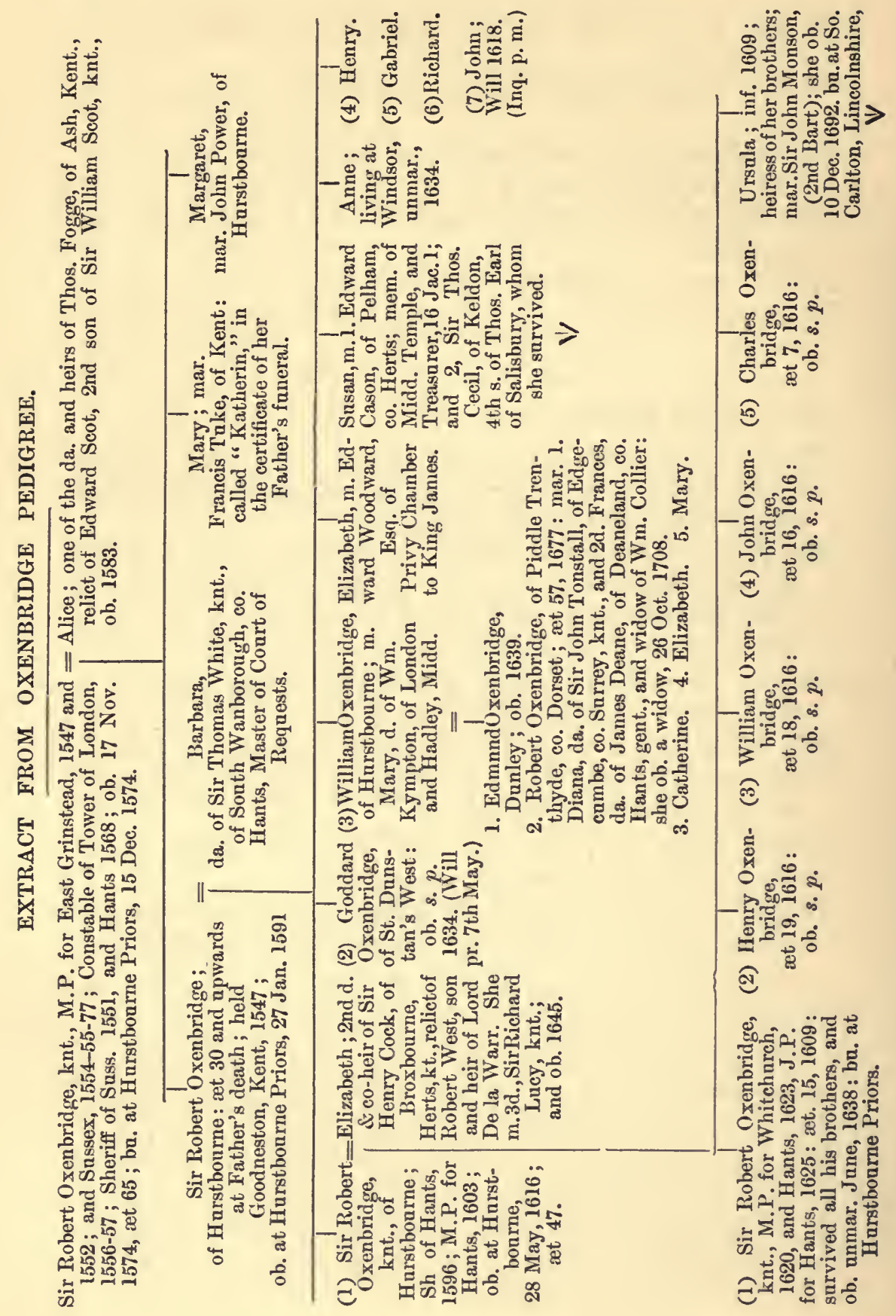


Thomas Horne and William Kidgill have ech of them $\mathrm{j}$ yard and halfe errable.

Robert Splott hath xx ac, errable.

Sum of Wheat in Weeke - j qrter iij buh.

The Tything of EgBerye.

Christian Goddard holdeth iiij yard land wherof ij yard land is ffreeland, and hath of both in wood viij ac., and is charged with the payment of wheate ij buh.

Richard Barnard hath iiij yard land of the La. Oxenbregge, and ij yard land to Buckett's downe and $x \times$ ac.: of Brighte's land, and hath in wood vj ac., and is charged with wheate ij buh.

William Nauell hath iiij yard land wherof in medow iij ac., and is charged with wheate ij buh.

John Godden hath ij yard land wherof in wood iiij ac.

William Bright hath iij yard land wherof in wood iij ac., and is charged with wheate $j$ buh.

George Godden hath iij yard land and viij ac. of pasture and charged with wheate $j$ buh.

Thomas Kidgill hath iij yard land and charged with wheate $j$ buh.

Bartholomew Broadway hath iiij yard land errable and charged with wheate ij buh.

Simon Taller hath iij yard land wherof in wood ij ac., and charged with wheate $\mathrm{j}$ buh.

Sum of Wheate in Egbery. - $\mathrm{j}$ qrter. iij buh.

The Tything of Binlye.

Christopher Kidgill holdeth iij yard land wherof in wood iij ac., and is charged with wheate ij buh.

William Gynes hath iiij yard land wherof in wood iij ac., and is charged with wheate ij buh.

Thomas Poore hath iij yard land wherof in wood iij ac., and is charged with wheato $\mathrm{j}$ buh.

Nicholas Philpot hath iiij yard land wherof in wood $\mathrm{v}$ ao., in medow $\mathrm{j}$ ac., and is charged with wheato ij buh.

Richard Downe hath ij yard land wherof in wood $\mathrm{j}$ ac. 
John Angell hath ij yard land errable and $\mathrm{v}$ ac. of pasture wherof $\mathrm{j}$ yard he holdeth of Sr. William Kingsmill, and the other of Mr. Richard Kingsmill, and is charged with the payment of wheate ij buh.

John Penton hath iij yard land wherof in wood $\mathrm{v}$ ac., in medow $\mathrm{j}$ ac., and is charged with wheate ij buh.

George Dyar hath ij yard land wherof in wood $\mathrm{j}$ ac.

Jeffery Poore and Richard Lardnar hath iij yard land wherof in wood iij ac., in medow $j$ ac., and is charged with wheate $j$ buh.

Thomas Nowell hath ij yard land wherof in wood iiij ac., in medow ij ac., and is charged with wheate $\mathrm{j}$ buh.

Christopher Skiner hath ij yard land wherof in wood iiij ac., in pasture $\mathrm{j}$ ac., in medow $\mathrm{j}$ ac., and is charged with wheate $\mathrm{j}$ buh.

Sum of wheate in Bynlie. - $\mathrm{j}$ qrter. $\mathrm{v}$ buh.

\section{Newetoune.}

John Harman hath viij ac. of pasture, ij ac. of medow, iij ac. of wood.

Walter Benham hath viij ac. of pasture, iij ac. of medow, vj ac. of wood of his free land, and in lease, xvj ac. of pasture, and iij ac. of medow.

William Stanbrooke hath in pasture ij ac., in medow $\mathbf{j}$ ac.

John Pierce hath vj ac. of pasture and ij ac. of wood.

Hellyer hath iiij ac. of pasture, $j$ ac. of medow.

Nicholas Holdway hath iiij ac. of medow and iij ac. of pasture.

Webbe hath ij ac. of medow and $j$ ac. of wood.

John White * hath ij ac. of medow.

the parson hath iij ac. of pasture.

William Meare hath $\nabla$ ac. of pasture, $i j$ ac. of medow.

John Holdway hath iiij ac. of pasture, $j$ ac. of medow, $j$ ac. of wood. Richard Marshall $j$ ac. of medow, Whetlands iij ac. of pasture, Smith, $\mathrm{j}$ ac. of medow,

\section{Sum of Acres in Newetoune - 100.}

* The family of White has been a prominent one in connection with this small parish for centuries. William le Whyte, of Woodhay, the ancestor no doubt of the Whites of this place, appears as a landholder here in the Taxation of Hants, 1334. 


\section{The Tything of Woodhaye.}

Edward Longman* holdeth the manor there in ffarme by estimacon vij yard land, wherof in pasture 1 ac., in medow xxx ac., the rest in errable: and heer is to be noted that within this tything of Woodhay ther is to euery yard land $1 \mathrm{x}$ ac.: and allso that the ffarmer hath wood allowed him for his ffewell and not otherwise, and is charged with the payment of wheate vij buh.

Mr. Edward Goddard † holdeth viij yard land and $l$ ac. of purposture, and hath in pasture lxxx ac., in medow $\mathrm{xxx}$ ac., in wood $\mathrm{xl}$ ac., the reste in errable, and charged with wheate vij buh.

William Rumbold holdeth the parsonage, and hath in gleebe lands xvij ac. errable, and holdeth of the Lord halfe a yard land wherof in medow $\mathrm{v}$ ac., in wood $v i$ ac., the reste in errable, more he holdeth in purposture xxiij ac., and is charged with wheat vj buh.

John Whittear $\ddagger$ holdeth in errable, xlviij ac, in medow $\mathrm{xx}$ ac., in pasture $\mathrm{xxxiij}$ ac., in wood $\mathrm{xx}$, and is charged with wheate $\mathrm{ij}$ buh.

- The Longman family has been connected with North Hants for several centuries. The tirst mention we find of the name is in a Subsidy Roll, under Woodcott, of Edward III., 1327. For many generations they held property as proprictors or occupiers at Week in the parish of St. Mary Bourne, and the surrounding neighbourhood. In the churchyard of Bonrne there are many monuments commemorating successive members of this finc old yeoman family, whose births, marriages, and deaths arc recorded in the parish registers from age to age with a regularity which might cause envy to some man of bricf pedigree, anxious to cxtend the line of his ancestry. The last inale representative of the Longmans at St. Mary Bourne was the lighly estecmed and benevolent owner of Wadwick or Warwick, a hamlet in the parish. An inscription under the Tower of the Parish Church records that the chandelier in the centre aisle of the church was the gift of Mr. John Longman, gent., of Apsley Farm, in the parish of Hurstbonrne Priors, in the year 1807.

+ Edward Goddard, of Stargrove. This fanily was one of considerable position and influence at the timc, and possessed a large property at Woodhay, which has passed into other hands. At Stargrove, after the second battle of Newbury, the then owner, John Goddard, received at his honse Oliver Cromwell, and the basin or bowl which he used on the occasion, was carefnlly prescrved by the family, and some years since deposited at the Rectory of East Woodhay, for safc and permanent custody, by the late Rev. Enilins Goidard, he being the last remaining member of that branch of the Goddards. In $1655 \mathrm{Mr}$. Vincent Goddard, of this family, was a Conmissioner under Cromwell for the county of Berks. In East Woodhay Church there is a handsome nonninent to Edward Goddard, son of Willian Goddard, of Stargrove, by Elizabeth his wife, danghter of John D'Oyley, Esq., " an eminent and hononrable family in the county of Oxford." Edward Goddard, the son, married Elizabeth, daughter of Edward Gordard, Esq., of Ogbourne St. Andrew, Wilts, and died 17 Oct., 1724. On the monument are full-sized figures of hinself and wife.

f John Whittear. This name, like many others, varies very much in its spelling. The Whitenrs were an old respectable, and ancient yeoman family, fast becoming extinct in Hampshire at the present time. The yeomen descendants of the Whitears are or were the owners of many manors and brond lands around Winchester and the neighbourliool. There are many gravestones in Alresford Church in memory of members of the Whitear family. 
George Knight holdeth ij yard land wherof in pasture vij ac., in medow vij ac., in wood xvj ac., the reste in errable, and more in purposture $x v j$ ac., and charged with wheate $j$ buh.

Richard Beckonsall holdeth $\mathrm{j}$ yard in errable, and lvj ac. wherof in pasture xxxiij ac., in medow $x$ ac., in wood xiij ac., and is charged with wheate $j$ buh.

Webbes' land is $\mathrm{xx}$ ac. of pasture.

Elizabeth Barbone* hath $\mathrm{j}$ yard land in errable, and halfe yarde land wherof in pasture, $\mathrm{xl}$ ac., in medow $\mathrm{ij}$ ac., in wood $\mathrm{x}$ ac., the reste in errable.

John Holdway, $\dagger$ of Sellhouse, $\ddagger$ hath $1 x$ ac., wherof in wood $\mathrm{xx}$ ac., in pasture $\mathrm{xx}$ ac., in medow $\mathrm{v}$ ac., in errable $\mathrm{xl}$ ac.

Richard Holdway hath $\mathrm{xl}$ ac. wherof in wood $\mathrm{xx}$ ac., in pasture $\mathrm{xx}$ ac. Mr. Henry Kingsmill, $\S \mathrm{j}$ medow, iiij ac., in pasture vj ac.

Robert Porter, $\mathrm{j}$ medow of $\mathrm{ij}$ ac., in pasture xiij ac.

William Stelle II a medow of iij ac.

Edward ffrome, a pasture of $\mathrm{xx}$ ac.

William Morgan, in pasture $\mathrm{x}$ ac., in medow $\mathrm{j}$ ac., in wood iij ac.

Bartholomew Rumbold, in pasture xxxiij ac., in medow ij ac., in $\operatorname{wood} \mathrm{v}$ ac.

John Wholdaye, in pasture ix ac., in medow iij ac., in wood iij ac., in errable $j$ ac.

Thomas Mascoll hath in pasture xx ac.

William Harte hath in pasture vij ac. in medow iij ac.

John Ironmonger T hath in pasture vj ac., in medow iiij ac.

* Elizabeth Barbone. Whether this was an ancestress of "Praise God, Barebone," whose real name was Barbon, "Barebones" being a play on the same, we cannot say, but it is one of very infrequent occurrence, and it is not improbable that "Praise God Barbon," who was a leather-seller in London, was descended from this North Hampshire stock. The name of John Barbone appears later as a customary tenant of the manor of East Woodhay.

$t$ John Holdway. The Holdways remained in unchanged and unbroken descent in North Hants for many ages, and they were a family of considerable importance hereabouts, for their names appear amongst those old yeomen families dignified by the highest honour, integrity, and worth. From generation to generation the name is found as owners or occupiers of land at St. Mary Bourne and neighbouring villages, but at last the good old stock has died ont. The last of the name was the benerolent lady occupant of Haven Hill.

$\ddagger$ Sellhouse. Now corrupted into "Zellhouse." Sellhouse, or Cellhouse, as often written, was probably so denominated because it stands on the chalk formation, which constitutes the geological construction of the spot.

$\S$ Mr. Henry Kingsmill. Afterwards Sir Henry Kingsmill, son of Sir William, of Sydmonton.

II Or Steele. This old line of yeomen was long continued at "Steele's Farm," Ashmansworth.

I Of the family of Iremonger, afterwards of Donnington Priory, and the Priory, Wherwell. 
Thomas Pinmore hath in pasture iij ac., in medow $\mathbf{j}$ ac., in wood iiij ac.

Richard Wheeler hath in pasture xv ac., in wood ij ac., in medow ij ac.

Bartholomew Welles, in pasture ix ac., in meadow $\mathrm{j}$ ac., in wood ij ac.

Agnes Androw, in pasture xxvj ac., in meadow iiij ac., in errable $\operatorname{xxx}$ ac.

Richard Beckonsall, in pasture ix ac., in medow ij ac., in wood $\mathrm{j}$ ac. John Durman, in pasture xiiij ac., in medow vj ac., in errable $\mathrm{xV}$ ac., in wood iiij ac.

Drewe Rumboll, in pasture $\mathrm{xl}$ ac., in medow iiij ac., in wood $\mathrm{xv}$ ac.

John Parker, in errable xij ac., in medow ij ac.

John Laske, in errable vij ac., in pasture iiij ao., in medow $j$ ac.

Richard Herne, in pasture lij ac., in medow viij ac., in wood $\mathrm{xx}$ ac.

Margery Harris, in pasture xiiij ac., in medow iij ac., in errable $x$ ac., in wood iij ac.

Robert Parker, $\mathrm{j}$ medow ij ac., in wood ij ac.

William Ballard, in errable $\mathrm{x} \nabla$ ac., in pasture $\mathrm{xv}$ ac.

John Humbard, in pasture $\nabla$ ac., in medow $\mathrm{j}$ ac.

John fforde, in pasture xiiij ac.

Thomas Kinge, in pasture $\mathbf{x}$ ac.

John Barbone, in errable vij ac., in pasture $\mathrm{j}$ ac., in medow ij ac.

John Alexander, in pasture xiijj ac., in medow vj ac.

Thomas Mansill, in pasture xiiij ac.. in medow ij ac., in wood iiij ac.

Elis ffielde, in pasture viij ac., in medow vj ac., in wood ij ac.

Thomas Abbington, in medow vij ac., in wood $x$ ac.

William Hellyer, in medow $\mathrm{j}$ ac., in pasture $\mathrm{xvj}$ ฉc.

John Angell, in pasture vj ac., in medow vj ac., in errable viij ac.

John Pesse, in pasture xv ac., in medow iij ac., in wood ij ac.

Agnes Osgood, in pasture xxij ac., in medow viij ac., in wood iij ac.

Elizabeth Hellier, in pasture xiiij ac., in medow vj ac., in errable ix ac., in wood $j$ ac.

Richard Laske, in pasture xj ac., in medow ij ac., in wood $\mathbf{j}$ ac.

Thomas Wallter, in pasture xvj ac., in medow iij ac., in errable $\mathrm{x}$ ac., in wood iij ac.

Richard ffielder, ${ }^{*}$ in pasture xxij ac., in medow ij ac., in wood $\mathrm{j}$ ac.

- Richard Fielder. This family can be traced iu old deeds and docnments to a very early period in the neighbourhood of Winchester and varions parishes in the northern division of Hampshire, where they possessed considerable landed property, and held many responsible positions. At the time of the 
Elizabeth Pearman, in pasture xvij ac., in medow ij ac., in errable $x$ ac., in wood $j$ ac.

Thomas Robinson, in pasture $\mathrm{xv}$ ac., in errable $\mathrm{x}$ ac., in medow iiij ac., in wood iij ac.

$$
\text { Sum of wheate in Woodhaye - iij quarters. }
$$

\section{The tything of ITchenswell.}

Henry Withers holdeth the manor in ffarme by estimacon $x$ yarde lande wherof in pasture xxxiij ac., and wood sufficient for his ffewel, and in medow xxj. ac., the rest in errable and charged with the payment of wheate $\mathrm{j}$ quarter.

Edward Withers holdeth the parsonage of Etchenswell, and hath $\mathrm{j}$ yard land in gleebe, wherof in medow $\mathrm{j}$ ac., the rest errable and charged with the payment of wheate iiij buh.

John Winckworth, sen., ij yard land wherof in pasture $x \mathrm{~V}$ ac., in medow $\mathrm{j}$ ac., in wood ij ac., and is charged with wheate $\mathrm{j}$ buh.

John Winckworth, jun., ij yard land wherof in pasture iiij ac., in medow vj ac., the wood ij ac., and is charged with wheate dim. buh.

ffrancis Wall hath ij yard land wherof in pasture $x x x$ ac., in medow $\mathrm{v}$ ac., and is charged with wheate $\mathrm{j}$ buh.

John Beuer hath xxx ac., wherof in pasture iiij ac., in medow $\mathrm{j}$ ac., the rest errable.

Peter Rowland, in errable $\mathrm{xxv}$ ac., in pasture $\mathrm{v}$ ac.

John Young, of Woodhay, in errable xviij ac., in pasture ij ac.

John Benham and Henry Witchers, in errable xiiij ac., in pasture xij ac.

Richard Morrice, in errable $x$ ac., in pasture xij ac., in medow $j$ ac. Ingram ffranckline, in errable xxij ac., in pasture $\mathrm{v}$ ac., in medow Thomas ffranckline, in errable $\mathrm{xxx}$ ac., in wood ij ac., in pasture $\nabla$ ac.

William White, in errable xviij ac., in pasture vij ac.

John Rumboll, in errable xvij ac., in pasture iij ac.

great rebellion, in the seventeenth century, Colonel Fielder was Governor of the Parliamentary garrison at Farnham, and in that capacity commanded the Surrey contingent engaged in the siege of Donnington Castle, and had previously done good service under Cromwell in other fields of action. The Fielders of Winchester and Newbury both descended from this old Hampshire race, and there are few families of whom so well-sustained a pedigree might be made out. 
William Reynold, in errable $\mathrm{xx}$ ac., in pasture $\mathrm{x}$ ac., in medow ij ac., in wood $j$ ac.

John White, in errable xviij ac., in pasture xix ac., in medow $j$ ac., in wood $\mathrm{j}$ ac.

John Reynold, in errable xviij ac., in pasture ix ac., in medow ij ac., in wood $\mathbf{j}$ ac.

Allice Younge, in pasture xxiij ac., in medow ij ae

Joane Younge, in errable xxx ac., in pasture viij ac., in medow ij ac.

Richard Swithine, in errable xiij ac., pasture xv ac., in medow ij ac.

Pawle Winckworthe, in errable iiij ac., in pasture $\mathrm{xx}$ ac., in medow $\mathrm{v}$ ac.

John Leggatt, in errable $\mathrm{xxx}$ ac., in pasture $\mathrm{xx}$ ac., in medow ij ac., in wood $\mathrm{j}$ ac.

Agnes Bolle, in errable vj ac., in pasture iiij ac.

Richard White, in errable viij ac., in pasture xj ac.

Edmond Winckworth, in pasture xiiij ac., in medow $\mathrm{j}$ ac.

William Prissmall, ${ }^{*}$ in errable ij ac., in pasture xxvj ac., in medow ij ac.

John ffosberrye, $\uparrow$ in errable xiiij ac., in pasture viij ac., in medow iij ac.

Walter Alfforde, in errable iij ac., in pasture $\mathrm{xx}$ ac., in medow ij ac.

Nicholas Whetland, in pasture $\mathrm{xx \nabla}$ ac., in medow $\mathrm{v}$ ac.

Walter Spencer, in pasture xxvij ac., in medow $j$ ac., in wood ij ac. Edmond Winckworthe, in pasture xj ac., in medow $j$ ac., in wood $v$ ac.

$$
\left.\begin{array}{c}
\text { Sum of wheate in the tything } \\
\text { of Itchinswell. }
\end{array}\right\} 1 \text { quarter vj buh. }
$$

\section{The tything of Ashminsworthe.}

John Cole holdeth the manor of Ashminsworth $\ddagger$ in ffarme by estimacon, vj yard land wherof in pasture xl ac., wch is the wood allowed for ffewell, and in medow $\mathrm{x}$ ac., the rest errable,

- The name of Prissmall still survives in the neighbourhood of Newbury.

t The Fosberrys are an old Hampshire family, some of whom were not long since living at Woodhay. The Fosberys of Clorane and Curraghbridge, in Ireland, derive their descent from an ancestor, anciently of Hanjphire, who settled in Ireland in the reign of William III., in whose army he held a commission in a regiment of dragoons. From him descended George Fosbury, Esq., of Clorane, high-sheriff of Limerick in 1743.

† Ashmansworth. The Anglo-Saxons brought their words over with them, and applied those words according to the character of the places where they settled. Their way was this. A namber of men settled on one spot. Erch had a portion of arable land, held under the principal lond, on which he lived; this was for his own exclusive ase. Bat their feeding groand, their pastare, as 
except lx ac., copis wood of wch the lord hath the pitt. The whole is charged with wheate iij buh.

Nicholas Wholdaye* hath ij yard land wherof in pasture $\mathrm{v}$ ac., in medow iij ac., in wood ij ac., and is charged with wheat $\mathrm{j}$ buh.

John Bacheler hath ij yard land there and if yard land in highclere, and hath of both in pasture xx ac., in medow ij ac., in wood $x$ ac., and is charged with wheate iij buh.

Allice Holdwaye hath ij yard land and vj ac. of purposture, wherof in wood iiij ac., in medow ij ac., and charged with wheat $\mathrm{j}$ buh. Thomas Penton, ij yard land errable.

Arthur Westcott, xij ac. errable.

Agnes Thurman, $\mathbf{j}$ yard land and a cossett wherof in wood vij ac., and of medow $j$ ac.

Thomas Holdwaye, $j$ yard land errable and $i j$ ac. of purposture.

John Coll, one yard land and dim. errable, and vij ac. of purposture.

Joane Holdwaye, i yard land dim., wherof in medow $\mathrm{j}$ ac., in wood $\mathrm{j}$ ac., in pasture ij ac.

Ann Stephens, $\dagger \mathrm{j}$ yard land dim., and $\mathrm{xx}$ ac. of purposture in medow $\mathrm{j}$ ac., in medow iij ac.

* The name of William Holdway, of Ashniansworth, occurs in a grant, 7 Edw. IV., 1467.

$t$ The name of John and Thomas Stephens, or Stevens, occurs in the above-nanied grant of 1467 , and on the south wall of the nave of Ashmansworth there has recently been disclosed under many coats of whitwash, the name of "John Stevens" in black letter, and the date "1533," indicating apparently his place of burial beneath.

we have shewn, was in common. So also in common, were the woods, and forest ground through which their animals ranged. Such names of places as end in worth, as in Ashmansworth, ton, tun, (meaning enclosure) ham, stead, and the like, all imply the settled habitation where the houses were. But such names as end in den, holt, wood, hurst, as in Hurstbourne, and others invariably denote forests, and roving pastures in forests. The word den, in particular, says Mr. Kemble, is a Saxon noun neuter, which always denotes woodland feeding. In the counties of Kent and Sussex, along the edge of the Weald (the Great Forest) there are many such names as Surrenden, Tenterden, Ashenden, and the like. There are so many of them, that within the last two centuries, there was actually a peculiar jurisdiction called the Court of Dens, for settling claims belonging to the woodland feedings. There is another word, dene, which neans a valley; but that is ancient British, not Saxon, and is very rarely found in composition. The Sason Den is woodland pasture. Brad is, of course, Saxon for broad, and Bradley as we have examples in North Hampshire, means the broad, open forest glades where the cattle love to lie. In a previous note we have referred to the Church of Ashmansworth having been given to the See of Winchester by King Athelstan; and during recent repairs evidences have been disclosed of what appears very much like Saron work, and in these stones it is not nureasonable to snppose we have a memorial of the original church founded by the Saxon king, and bestowed by him on the Monks of Winchester. At the foot of the northeast quoin of the chancel a piece of Roman stone has been used, which probably came from Silchester. 
Thomas Hellyer, $\mathrm{j}$ yard land and dim. errable.

Walter Holdwaye, $\mathrm{xx}$ ac. of purposture, ${ }^{*}$ wherof $\mathrm{j}$ ac medow and $\mathrm{j}$ ac. of wood.

John Walter hath $\mathrm{xx}$ ac. of purposture.

John Neale hath $v$ ac., of errable and in medow $j$ ac.

Sum of wheat in Ashmansworth - viij buh.

\section{The Tything of HIGHCLERE AND HAwCLERE.}

Mr. Richard Knight $\dagger$ holdeth the manor of highclere ffarme by estimacon $\mathrm{x}$ yard land errable, and hath for his pasture xlij, cattell going in the parke, and is charged with wheat vj buh.

- Purposture, i.e. P'urpresture. Is the making of buildings and enclosures within the limits of a forest. The Crown would sometimes give license of purpresture; and sometimes a title by long prescription to enclosnres which must have been originally purprestures, though no one could prove when the appropriation of the land had taken place. So in consse of time the forests got very much encroached apon. Purpresture here appears land enclosed from the waste, and scems to include not only land wrongfully so enclosed, but such as was separated with the consent of the owner.

$\dagger$ The Knight family were not only lessees of the manor of Highclere, but also of the Great Tithes of Kingsclere, in which parish they also held considerable other property. A family of the name possessed the manor of Crookham, on the Hampshire border, and in 1548 John Knight, gent., of Newbury, had considerable grants of property belonging to the dissolved chantries attached to the parish church there. But the North Hampshire branch of this widespreading family, which held considerable property at Highclere, Kingsclere, and neighbouring parishes appears to have sprung from the Knights of Chawton, near Alton, of which we append a short sketch of descent:

William Knight, of Chawton =Agnes, 1525.

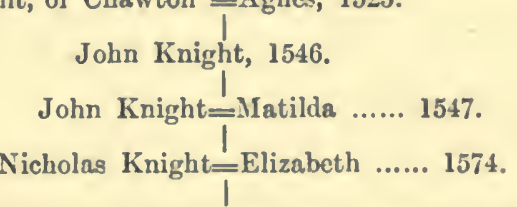

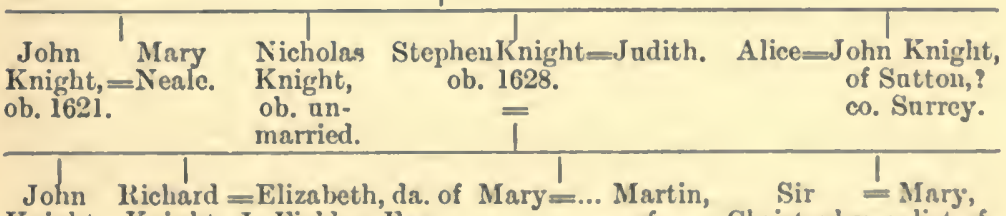

Knight Knight J. Ficlder, Esc.,

of

"Barrow-court,"

co. Berks, 1637. of Christopher relict of

co. Oxoll. Recorier of

Chichester.

(2nil hus-

band). 
Mr. Gunter* holdeth the parsonage and hath ij yard land wherof in pasture xvj ac., in medow iiij ac., wood iij ac., errable xxiiij ac., and is charged with wheate ij buh.

Robert Beckonsall hath $\nabla$ Cossett landes, errable and of purposture $I$ ac., and in medow $\nabla$ ac., in wood $v$ ac., and is charged with wheate ij buh.

John Sawyer hath iiij yard land wherof in errable xl ac., in wood $\nabla$ ac., in medow iiij ac., in pasture xj ac. $\mathrm{j}$ buh.

Philip Comen hath ij yard land wherof in pasture $\mathrm{x}$ ac., in medow iiij ac., in wood vj ac., and charged with wheate $j$ buh.

Peter Waterman hath iij yard land and $\mathrm{xx}$ ac. of pasture, and in wood vj ac., in medow iij ac., charged with wheate $\mathrm{j}$ buh.

Morrice Cooper hath ij yard land, and xij ac. of pasture, and in wood iij ac., in medow iij ac., charged with wheat $j$ buh.

Edward ffrome, in errable $x \times x \nabla$ ac., in pasture $x x$ ac., in medow vi ac., in wood $x$ ac., charged with wheate $j$ buh.

Anthony Beanes, in pasture $\mathrm{x}$ ac., in medow $\mathrm{j}$ ac., errable iiij ac.

John Greene, errable $x \nabla$ ac., medow j ac., wood ij ac.

William ffroome, in pasture $x \nabla$ ac., in wood $j$ ac., in medow iiij ac.

William Stile, in pasture $\mathrm{v}$ ac.

William ffollowell, in medow xj ac.

John Younge, in medorv viij ac.

John Huniwell, in errable $x \vee$ ac., in medow ij ac., in wood ij ac.

Allice Pricksmall, in errable $\mathrm{x}$ ac.

Roger Louinge, in errable $x$ ac., in wood ij ac.

William Young, in errable $\mathbf{x}$ ac., in medow iij ac., in wood iij ac.

John Alle, errable iiij ac., pasture iiij ac., medow ij ac.

Peter Louinge, in pasture $\mathrm{xx}$ ac., Richard Hine in pasture $\mathrm{xl}$ ac.

John ffroome, in pasture iiij ac.

William White, in medow iiij ac., in wood iij ac.

Sum of Wheat in highclere and hawclere - j qrter. vij buh.

* Mr. Gunter. The lessee or farmer of the Great Tithes was most probably Mr. John Ganter, of Barton Conrt, Kintbary, who died in 1624, aged 89. The family settled at Kintbory about the year 1407, and continued till 1695, it then became extinct. 


\section{The Tything of Burrowcleare.}

Mr. John Beckensall* holdeth the manor of Burrowcleare in ffarme by estimacon xij yard land wherof in pasture lxxx ac., in medow $\mathrm{xx}$ ac., the rest in errable, and hath wood allowed for his ffewell in the Lord's woods, and charged with the payment of wheate xj buh.

The said John Beckonsall holdeth the parsonage hauing in gleebe of errable land lxxx ac., in wood ground $\mathrm{x}$ ac., in pasture iiij ac., in medow ij ac., and is charged with the payment of wheate xij buh.

The said John Beckonsall holdeth $\mathrm{j}$ yard halfe, and Cosset of Copie hould lande, wherof in pasture xvj ac., in medow ij ac., the reste in errable, and also in purposture and woods vj ac., for the whole charged with wheate $\mathrm{j}$ buh.

William Cleue hath iiij yard land wherof in medow viij ac., in pasture xxiiij ac., in wood $\mathrm{j}$ ac., and more of purposture land in wood and pasture xxx ac., charged with wheate ij buh.

- John Beckensall. This is a local rendering of Beconshaw, or Beckenshaw. John Beconshaw, the first of this family settled in Hampshire, was the son of John Beconshaw, of Ieconsliaw in Lancashire. He was resident at Hartley Westpall. His second son, John, was a fellow of New College. and Professor of Greek, in Paris. He died at Sherborne St John, in 1559, and was buried in the charch there. His yonngest son, Walter, settled at Hartley Westpall. John Beconshaw, of Burghclere, the head of the family, grandson of Edward, brother to the Fellow of New College, and Walter Beconshaw, married Anne, danghter to Nicholas Tichborne, by whom he had a son Peter, who is described as of Burghclere William Beconshaw, son of Richard, and grandson of Walter Beconshaw, by his marriage with Alice, danghter and leiress of William White, of Moyles Court, M.P. for Lymington in 1589, brought the Moyles Court Estate into the family. Alice, wife of Sir John Lisle, the Regicide, and who swore Cronwell in as Lord Protector, as co-heiress of her father Sir White Beconshaw, took Moyles Court into the Lisle family. It was this Alice Lisle, née Beconshaw, who was brought ap before the infamons Judge Jeffreys on the charge of treason, for having given shelter to Hickes and Nelthorpe, fagitives from the field of Sedgemoor. Her own loyalty was andoubted, and she had a son in the king's army, but her husband Colonel Lisle had been one of the judges at the trial of Charles I., and was shot dead at Lousanne by three hired ruflians. His widow was now marked for rengoance by Jeffreys, and after a conviction, forced by the bratal judge from a jury who had twice retarned a verdict of not gailty, she was condenned, and executed at Winchester, 2 Sept, 1685. Edward Lisle, of Crux-Easton, the anthor of the well-known work on Agriculture, was son of Sir William Lisle, a zealous royalist, with Charles II. in exile, brother to Sir John Lisle, the Regicide, and father of Dr. Thomas Lisle, anthor of "Porsenna," who died Rector of Burghclere in 1766.

The story of Alice Lisle, a very marked episode of the rebellion, is, as is well-known, the subject of a fresco in the Palace of Westminster.

The names of John Beconshaw, Peter and Nicholas Tichborne, and William Beconshaw appear in a "Catalogue of papists" in 1579, who appear to have been in prison as Recusants for more than two years. 
The said William Cleue hath more $\mathrm{j}$ yard land and dim., wherof in medow iij ac., in pasture vj ac., in purposture $x$ ac., the rest errable, and charged with the payment of wheat $j$ buh.

William Eeles * hath $\mathrm{j}$ yard land in errable, more in pasture $\mathrm{xx}$ ac., in medow iijj ac., in purposture xvj ac., and is charged with the payment of wheat $\mathrm{j}$ buh.

Simon Eeles hath ij yard land in errable and more, and a Cossett land, and also vj ac. medow, and $\mathrm{xx}$ ac. wood ground, and more in pasture vj ac., and more in errable iiij ac., and is charged with the payment of wheat ij buh.

John Alle hath $\mathrm{j}$ yeard land and a Cossett in errable besides iiij ac., medow iij ac., wood and in pasture and purposture $\mathrm{xxxvj} \mathrm{ac.,}$ charged with the payment of wheate $\mathrm{j}$ buh.

William ffollowell hath $j$ yard land and a Cossett wherof in errable $\mathrm{xxx}$ ac., in pasture xliiij ac., in medow $\mathrm{xx}$ ac., in wood viij ac., and is charged with wheate $j$ buh.

John Herryett hath $\mathrm{j}$ yard land and a Cossett in errable and more in pasture xiiij ac., in medow $\mathrm{v}$ ac., and is charged with the payment of wheate $\mathbf{j}$ buh.

Agnes Cooper hath in errrble $x v$ ac., in medow viij ac., in pasture $\mathrm{xj}$ ac., in wood ij ac.

John Wheeler, jun., in errable xxx ac., in medow ij ac., in pasture vj ac., and in highclere iij ac. pasture.

John Gaston, in errable iiij ac., in pasture vij ac., in medow $\mathrm{j}$ ac.

John Bronsdowne, in errable iij ac., in pasture $\mathrm{j}$ ac., in medow $\mathrm{j}$ ac.

John Wheeler, senior, $j$ yard land and $x$ ac. in errable, and in pasture and purposture $x x x$ iij ac., in medow vij ac., in wood ground $\mathrm{x}$ ac.

Richard Wheeler, dim. yard land in errable, and in medow ij ac., in pasture iij ac.

John Arundell, $\uparrow$ yard land in errable, in pasture and purposture xxiiij ac., in wood viij ac., in medow $\mathrm{v}$ ac.

Thomas Alle, dim. yard land and ix ac. in errable, in pasture xiij ac., in purposture $x x x$ ac., in medow iij ac., in wood ground $x$ ac.

* William Eeles. This family has continued withont intermission been settled at Kingsclere, Highclere, and the neighbourhood from Elizabethan days to the present. The name is most corruptly and diversely spelt, and with that of Eyles appears to have had a common origin.

+ The Arundells of Burghclere, Brimpton, Newbury, and elsewhere in the neighbourhood, represented a branch of the ennobled house of Arundell of Wardour. 
Philip A-lee, dim. yard land in errable, and in pasture ij ac., in medow iij ac.

John Clarke, dim. yard land errable, and in pasture $\mathrm{x}$ ac.

John Steptoe hath xxxiiij ao., wherof in medow iiij ac., in pasture $\mathrm{xxx}$ ac.

Elinor Arundell, dim. yard land errable, in medow ij ac., in pasture vij ac., in purposture vj ac., and $\mathrm{j}$ ac. of wood.

John Peirce, dim. yard land errable, and in pasture $\nabla$ ac., in medow $\mathrm{j}$ ac.

Agnes Peirce, dim. yard land, and in medow ij ac., in pasture vj ac., and in purposture $\mathrm{v}$ ac.

William Arundell, in purposture $\mathrm{x}$ ac., in pasture iiij ac., in medow $i$ ac., in wood $v$ ac.

John White, iij Cossett landes errable, in medow vij ac., in pasture viij ac., in purposture $\mathrm{xx}$ ac., and in wood ground $\mathrm{xxij}$ ac.

Richard Brooke, iiij Cossett landes wherof in medow $\mathrm{x}$ ac., in wood iij ac., in pasture xij ac., in purposture $j$ ac.

Peter Hould, i Cossett dim. land wherof in medow $\mathrm{j}$ ac., in pasture iij ac.

Joane Dickon, ij Cossett landes wherof in medow ij ac., in pasture sviij ac., in wood iiij ac.

Richard Crooke, $\mathrm{j}$ yard land, wherof in pasture xxij ac., in purposture xij ac., in medow vj ac., in wood vij ac., in errable xx ac.

John Miskine, dim. yard land and a Cossett, wherof in pasture vj ac., in medow $\mathrm{j}$ ac., in purposture iiij ac.

John Attwell, dim. yard land, dim. Cossett, wherof in medow ij ac., in pasture iij ac.

John Oliner, i Cossett land wherof in pasture ij ac.

Simon Wendbolte, dim. yard land, wherof in modow $j$ ac., and in pasture, iij ac., and more in purposture iij ac.

John Torroway, i yard land and dim. in errable and in medow iij ac., in pasture vj ac., and in purposture vj ac.

William Withers, dim. yard land wherof in pasture $x \times$ ao., in medow ij ac., in wood vj ac., and more in purposture $x$ ao.

$\left.\begin{array}{c}\text { Sum of wheate in the Tythinge } \\ \text { of Burrowcleare }\end{array}\right\}$ iiij qrters. $\mathrm{j}$ buh. 
The Tithing of Baghurste.

Sr. William holdeth the parsonage, and hath ij ac. of pasture for his gleebe, and charged with wheate $\mathrm{j}$ buh.

John ffreeborne hath xv ac. errable

William ffreeborne hath $\mathrm{xxx}$ ac. errable, and more in wood iij ac., in medow ij ac.

Thomas Harmsworth hath $x x x$ ac., wherof in medow $j$ ac.

William Dyker hath xxx ac. errable, and iij ac. medow, and in wood ij ac.

Richard Losse hath xviij ac. in errable, and ij ac. in wood.

William Sweetapple hath in errable iiij ac.

Thomas Nott, in pasture ij ac.

Thomas Peuike ij ac. errable.

Richard Withers, xxvj ac. errable, and in wood iij ac., in medow $\mathrm{j}$ ac.

William Deane, ij yard landes errable, and more in wood iij ac., in medow iiij ac.

Robert Greene hath xxx ac., wherof in medow ij ac., in wood ij ac. William Bye hath xxiij ac. errable, in wood $\mathrm{j}$ ac., in medow $\mathrm{j}$ ac.

John Spencer hath $\mathrm{j}$ yard 'land errable, and more in wood iij ac., in medow ij ac.

Nicholas Potter hath $\mathrm{j}$ yard land errable, and in wood $\mathrm{j}$ ac., in medow ij ac.

William Seward hath xiij ac. errable, and in wood $j$ ac., in medow $\mathrm{j}$ ac.

Ingram Baghurste hath xxx ac. errable, and in wood iij ac., in medow ij ac.

John Mershe hath xviij ac. errable, $\mathrm{j}$ ac. wood, and in medow $\mathrm{j}$ ac. William ffreeborne hath of errable xvj ac., in medow ij ac.

Sum of wheate in Baghurst

- j buh

The hundred of Pastrowe.

The Tything of Woodcort.

William Still hath in his occupacon 150 ac., wherof $80 \mathrm{ac}$. ar in the

Comon ffeldes, and 20 ac. of pasture, $\mathrm{v}$ ac. of wood, and ij ac. in medow, the reste in tillage in seuerall, charged with wheate iij buh.

Thomas Taylor hath in his occupacon lxxvj ac., wherof xl ac. lyeth in the comon ffieldes, and viij ac. ar pasture, vij ac. Copie ground, and $i j$ ac. medow, the residew tillage in seuerall. 
Edmond Winckworth hath in his occupacon lxx ac. in the comon ffieldes : $\mathrm{j}$ ac. of wood ground, ij ac. in meadow, and viij ac. in pasture.

Thomas Tayler and Edmond Winckworth ar charged with wheate iij buh.

Drewe Rumboll hath in his occupacon xlvij ac., wherof xl ac ar in the comon fieldes, $\nabla$. ac. of Copis ground, and ij ac. in medow. charged with wheate $\mathrm{j}$ buh.

Simon Still hath in his occupacon $x \times x$ ac., wherof $j$ ac. is copis ground, xxiij ac. ar in the comon fieldes, and the reste tillage in seuerall.

Robert Kente hath in his occupacon xxxij ac., wherof xxiij ac. lieth in the comon fieldes, $\mathrm{j}$ ac. is wood ground and halfe an acre medow, the residew tillage in seuerall.

Richard Kcnte has in his occupacon $\mathrm{xxx}$ ac. wherof xxij ac. lye in the common fieldes, $\mathrm{j}$ ac. is copie ground, and one acre medow, the resider is tillage in seuerall.

The Tything of Woodcott charged with wheat:

\} - vij buh.

\section{The Tything of Cruxeastox.}

The parsonage of Cruxeaston xvj ac. errable in gleebe: the ffarm of Crux eastin in the occupacon of William Temple* 350 ac. errable, and iijj ac. dim. medow, $\mathrm{xx}$ ac. of bushie pasture, and lx ac. errable belonging to his tenements, and of meadow iij ac. halfe of Copis ground viij ac., and more xl ac. of Copis ground: the underwood and herbage belongs to the said William Temple: and the wood to the Lord, charged with wheat xj buh. Thomas Parker hath in his occupacon lxvj ac. errable, and onc ac. of medow ground and vj ac. of Copis ground, the wood and herbage is his owne, and charged with the payment of whea $j$ buh.

The Tything Cruxeaston charged with wheate xij buh.

* The family of Temple had at this period spread into several branches, and it is difficalt to identify the gentleman named in the text. There is a pedigree of this ancient and long enduring honse in Nichols" "History of the Connty of Leicester," and many particulars of the family will be found in the pages of the "Herald and Genealogist," bat no mention is made of this layrector of Crax Easton. Very probably, however, he was the son of John Temple, of Kingston Deverell, co. Wilts, described in Hoare's "Modern Wilts," as William Temple, of Bishopstrow, gent. In 1637, a William Temple purchased the fee of the inanor of Bishopstrow, of James Tachet, Lord Audley, and Castlehaven. 


\section{The Tything of FFACCOMBE.}

The ffarme in the occupacon of $\mathrm{Mr}$. Reade, ${ }^{*} 150$ ac., in the comon fieldes, and ffiftio acres errable in seuerall, iij ac., of meade ground, 110 ac. of Copis ground, the wood, the Lords, the herbage John Helliers until it be vij yeares owld, and then it is comon.

* The Reades of Faccomb were people of note here in the 16th and 17th centuries, and allied to the Dymokes of Scrivelsby, the Windebanks, and other historic houses. On a fine brass, set in alabaster, formerly in the old Church at Faccombe, is the following inscription:- "Heare lyeth ye body of Anne Reade, ye deare wife of Henry Reade, Esq., one of ye daughters of Sir Thomas Windebank, knight, Clarke of ye Signet to the late Queen Elizabeth, and to King James that now is. She was begotten of ye body of Frances Dymmocke, his wife, one of ye daughters of Sir Edward Dymmocke, of Serivelsby, in ye county of Lincolne, Knight Champion to ye said Queen Elizabeth, and her saccessors, by the tenure of his landes. She departed this life to rest with her Saviour Christ, 17th day of June, 1624, in ye 53rd yeare of her age, and left behind her issues of her body, living, two sones and three daughters, Margret, Mildred, and An." Sir Edward Dymoke officiated as Champion at the Coronation of Edward VI., Queen Mary, and Queen Elizabeth. Alice Reade, wife of Robert Reade, gent., of Linkenholt, was buried in the chancel of the old Church, Oct., 1596. The family of Dymoke still retains its singular office of Champion, which it derives from the baronial house of Marmyon, with the fendal manor of Scrivelsby, to which the championship is attached. Of this family Henry Reade sat for Andover in the Parliament of 1588, and John Reade, b. 1579, was a Scholar of Winchester College. Thomas Reade, of Linkenholt, b. 1606, was a Scholar and Fellow of New College, D.C.L., Advocate of Arches Court, Principal Magdalen Hall, 1643. He fought for the king, and died in the Charterhouse 1669. Robert Reade, b. at Faccombe, 1642, Scholar, and Fellow of New College, succeeded to the Faccombe property in 1668. On a marble Tablet formerly in the Chancel of the ancient Church of St. Michael, Faccombe, now destroyed, was the following inscription :-

M. S.

SVB CERTA RESVMENDI SPE

MORTALITATIS SVAE EXUVIUS

HENRICVS READE ARMIGER ANDREæ F.

QVI

CVM DEO PRINCIPI PATRIA LONGVM ET FIDELITER

INSERVIISSET

PER AESTVOSVM HVNC VIT AS OCEANYM

VARIIS ACTVS TEMPESTATIBVS

ANNO SVPRA OCTOGESIMVM PRIMO

CLIMACTERICO SVO MAGNO

PORTVM DEMVM INTRAVIT

QVARTO APRIL

MDCXLVII.

FRANCISCVS READE FILIVS ET HARES

PIETATIS ET OFFICII ERGO

MOER. MOES. POS.

The sword-an Andrea Ferrara, and helmet said to have been worn in the wars, by this unbending and chivalrous cavalier, were formerly suspended over this monument, bat were removed when the old Charch was palled down. 
The parsonage of ffaccombe in the occupacon of Mr. Reade, xxviij ac., in glebe, wherof vj ac. in seuerall : the Lord Sandes, and hath three score and tenn ac. of Copis wood, the wood my Lords, and the herbage to whom my Lord shall please.

The ffarme and parsonage of ffaccombe charged with wheat $x$ buh.

Robert Wadlow hath in his occupacon 120 ac., wherof $x l$ ac. ar in the comon ffieldes, and ij ac. medow, the residew tillage in seuerall.

Thomas Bulpitt hath in his occupacon 120 ac. errable in seuerall, ij ac. in medow, and the said Thomas Bulpit hath $\mathbf{x x}$ ac. errable in common wherof $\mathrm{ij}$ ac. ar in seuerall, dim. ac. in meade ground, $\mathrm{v}$ ac. in Copis ground, and the wood Mr. Erlyes, the herbage belongeth to the said Thomas untill it be vij yeares owlde.

Robert Wadlow and Thomas Bulpitt charged with the payment of wheate $\mathrm{v}$ buh.

Thomas Hellyer hath in his occupacon $1 x$ ac. errable, wherof $x l v$ ac. ar in seuerall, $j$ halfe ac. in meade ground, and the residew in the comon fieldes, charged with wheate $\mathrm{j}$ buh.

John Bunny hath in his occupacon xliiij ac. errable, wherof $x \mathrm{v}$ ac., do lye in the comon fieldes, and dim. ac. in mead ground, the residew tillage in seuerall charged with wheate $\mathrm{j}$ buh.

Agnes Hellyer hath in his occupacon xlv ac. errable, wherof $x x x$ ac. in seuerall, $x \nabla$ ac. in the comon fieldes, and $j$ ac. in medow ground, charged with wheate, $j$ buh.

William Lake hath in his occupacon xlv ac. errable in seuerall, and $v$ ac. of Copis ground, the wood the Lords, the herbage doth belong to the said William, charged with wheat $j$ buh.

Rowland Louelocke hath in his occupacon 1 ac. errable, wherof $\mathrm{xxx}$ ac. ar in seuerall, and $\mathrm{xx}$ ac. in the comon fieldes, and one acre meade ground, charged with wheate $j$ buh.

Valentine Bulpitt hath in his occupacon xliiij ac. errable, wherof xxiiij ac. ar in seuerall, $x x$ ac. in the comon fieldes, $j$ ac. of meade ground and $\mathrm{v}$ ac. of Copis ground, the wood the Lords, the herbage to the said Valentine, charged with wheate $j$ buh.

John Goodale hath in his occupacon 1 ac. orrable, wherof $\operatorname{xxx}$ ac. in seuerall, $x \mathbf{x}$ ac. in the comon fieldes, $\mathrm{j}$ ac. of medow and iij ac. in Copis ground: the wood the Lords, the herbage to the said Goodalle, charged with wheato $\mathrm{j}$ buh.

John Pierce hath in his occupacon $l$ ac. errable wherof $\mathrm{v}$ ac. lyo in seuerall, and $\mathrm{xl} \mathrm{ac}$. in the comon fieldes, and $\mathrm{j}$ ac. in meadow ground. 


\section{2 a Royal pURveyance in the elizabethan age.}

Ambrose Brooker hath in his occupacon xl ac. errable, wherof iij ac. in seuerall, the reste in the common fieldes, and $\mathrm{j}$ halfe ac. in meade ground.

John Cooper hath in his occupacon 1 ac. errable, wherof xxx ac. in seuerall, $\mathrm{xx}$ ac. in the comon ffieldes, and halfe an ac. in meade ground.

William Deane hath in his occupacon $\mathrm{xxx}$ ac. errable, wherof viij ac. in seuerall, the reste lyeth in the comon ffieldes, and dim. ac. in medow ground.

John Pierce, Ambrose Brooker, John Cooper, and William Deane, one lambe between these iiij, price iijs. iijd.

Mr. Sweetwell hath in his occupacon xxiiij ac., in seuerall, and halfe an acre in medow, and iij halfes in wood ground, the land all his owne, and charged with the payment of $\mathrm{j}$ goose.

Anthony Boswell hath in his occupacon xxiiij ac. arable in seuerall, * and three halfes in Copis ground.

Richard Wigmore hath in his occupacon xxvj ac. errable in the common ffieldes and $j$ ac. in meade ground, charged with $j$ Capon.

Agnes Bulpitt hath in her occupacon xxij ac. errable, wherof xij ac. in seuerall, and $\mathrm{x}$ ac. in the comon fieldes.

Mawde Hellier hath in her occupacon xxvj ac. errable, wherof vj ac. in seuerall, and dim. ac. in meade ground, and $x x$ ac. in the comon ffieldes, charged with ...... j Capon.

Thomas Pierce hath in his occupacon xx ac. errable, wherof viij ac. in seuerall, and xij ac. lye in the comon ffieldes, and iij ac. in wood ground, all his owne land, and charged with ...... j goose.

John Cumen hath in his occupacon xij ac. errable, wherof iiij ac. in seuerall, and viij ac. in comon, and dim. ac. in medow.

John Cole hath in his occupacon xij ac. errable, wherof iiij ac. in seuerall, viij ac. in comon, and halfe ac. in medow.

John Groodall hath in his occupacon xij ac. in seuerall and $j$ ac. in Copis ground, the wood the Lords, the herbage the said Goodalls.

John Hellier hath in his occupacon viij ac. errable, wherof vj ac. in seuerall, $i j$ ac. in comon, and $j$ ac. of medow.

$$
\left.\begin{array}{c}
\text { Sum of wheate in the Tything } \\
\text { of ffaccombe. }
\end{array}\right\} \text { ij qrters. vj buh. }
$$

* Senerall or Severalty. "He that holds lands or tenements in severalty, or is sole tenant thereof, is he that holds them in his own right nnly, without any other person being joined or connected with him in point of interest, during his estate therein." Blackstone Com. 
The Tything of CoxHoLtre.

William Hellier hath in his occupacon 140 ac.. wherof 90 ac. ar errable; and 60 ac. pasture, iij ac. meade ground, $\mathbf{v}$ ac. of wood, the herbage and the underwood his owne: charged with wheate, จ. buh.

William Phare hath in his occupacon 1 ac. errable in the comon ffieldes, and one acre halfe meade ground charged with wheat j buh.

John Page hath in his occupacon xxiiij ac. errable in the comon ffieldes, and dim. ac. meadow.

John Piper hath in his occupacon xij ac. errable in the comon ffielde.

Thomas Hellier hath in his occupacon xl ac. errable, wherof xj ac. lye in seuerall, and the reste in comon fieldes, and halfe an ac. of medow, charged with wheate $\mathrm{j}$ buh.

Alice Wilcoxe hath in his occupacon vij ac. errable lying in the comon fieldes.

Sum of wheate in Conholte - vij buh.

\section{The Tything of Phernams Deane.}

Thomas Hellyer hath in his occupacon 120 ac. errable in comon, lxxx ac. in seuerall, and iiij ac. of medow, charged with the payment of wheate vj buh.

Mr. Burley* hath in his occupacon xxvj ac. Copis ground belonging unto him and the herbage to Thomas Hellycr and now the said Burley claimeth it from him, and the said Thomas hath ij ac. of wood ground of his owne.

Thomas Rogers hath in his occupacon 120 ac. in the comon fieldes, $j$ ac. of medow, $j$ ac. of wood ground, and iij ac. of pasture: charged with wheate iij buh.

* The Barleys were a family of old settlement at Longparish. Capt. Symonds in his "Diary of the Marches of the Royal Army," mentions a monumental brass then in Longparish Church commenorating Richard Burley, gent., ob. 1541, and Agnes his wife, ob. 1557. The shield bearing these arins:Quarterly, 1 and 4, three boars' heads coupled [Burley]: 2, a chevron engrailed [? wavy], between three cross-crosslets [Bonhain]; 3, three spears erect in fess. Crest, a demi-boar holding a thistle. "These Burleys" he adds, lived at the manor, and farmed it of the Lord Delaware, who lived at IIorwell [Wherwell] in this county of Hampshire." IRichard Barley, of Middleton Hall Longparish, was the son of William Burley, of Devizes, Wilts. 


\section{A ROYAL PURVEYANCE IN THE ELIZABETHAN AGE.}

Mr. Burlye hath in his occupacon xvj ac. of wood belonging to the same ffarme, the herbage wherof belongeth to the above said Thomas Rogers.

Thomas Liuelocke hath in his occupacon xl ac. errable ground in the comon ffieldes and $\mathrm{xx}$ ac. in seuerall, and halfe an ac. of meade ground: Mr. Burlye hath viij ac. of the same hould in wood ground reserued unto him.

Thomas Wooldridge hath in his occupacon 1 ac. errable in the comon ffieldes and $\mathrm{x}$ ac. in seuerall, dim. ac. medow, and dim. ac. of wood ground.

Thomas Liuelocke and Thomas Wolridge* charged with wheat, iij buh.

Thomas Hopgood hath in his occupacon $\mathrm{xv}$ ac. errable in the comon ffieldes and $\mathrm{xxv}$ ac. in seuerall, and ij ac. of wood ground and halfe an acre of meade ground.

John Isgate hath in his occupacon $x x x$ ac. errable in the comon ffieldes: $x$ ac. errable in seuerall, dim. ac. wood ground and dim. ac. in medow charged with wheate $\mathrm{j}$ buh.

Richard Hunte hath in his occupacon xxx ac. errable in the comon ffield $\mathrm{xxx}$ ac. in seuerall, $\mathrm{j}$ ac. of wood and dim. ac. of medow charged with wheate $j$ buh.

1. Thomas Smarte hath in his occupacon xxx ac. errable in seuerall.

2. Thomas Broker hath in his occupacon 1 ac. errable in the comon ffieldes and dim. ac. of medow.

3. William Pike hath in his occupacon xl ac. errable in the comon ffielde.

4. Ideth Bennett hath in her occupacon xx ac. errable in comon, $x$ ac. in seuerall, ij ac. of wood ground, and iij ac. medow.

Thomas Smarte, Thomas Broker, William Pike, Ideth Bennett, these iiij charged with $\mathbf{j}$ lambe between them price iijs. iiijd.

Rowland dewman hath in his occupacon $\mathrm{xxx}$ ac. errable in comon, and iij ac. errable in seuerall, charged with $\mathbf{j}$ henne.

William Blissett hath in his occupacon $\mathrm{xxx}$ ac. errable in the comon ffielde, and dim. ac. medow charged with $\mathrm{j}$ pullett.

John North hath in his occupacon $\mathrm{xxx}$ ac. errable wherof iiij ac. lve in seuerall, the rest in common charged with $\mathrm{j}$ pullett. Simon Woldridge hath in his occupacon $\mathrm{xv}$ ac., wherof $\mathrm{v}$ ac. lye in seuerall, the reste in comon, and dim. ac. of medow.

* The name of Wooldridge is still represented at Winchester and the district. 
Thomas Tayler hath in his occupacon vij ac. in comon and viij ac. in seuerall.

Robert Anker * hath in his occupacon 1 ac. errable in seuerall, $j$ ac. of wood, and $\mathrm{j}$ ac. medow charged with wheat $\mathrm{j}$ buh.

John ffellow hath in his occupacon $x v$ ac. in common and $j$ ac. in seuerall, charged with

j henne.

John Hedges hath in his occupacon xvj ac. errable, wherof $\mathrm{x}$ ac. lye in comon, and vj ac. in seuerall, and dim. ac. medow, $\mathrm{j}$ henne. John Liuelocke hath in his occupacon $\mathrm{xxx}$ ac. errable in comon, $\mathrm{x}$ ac. in seuerall, ij ac. of medow, and $\mathrm{j}$ ac. wood ground, charged with wheate

William Barrett hath $\mathbf{x v}$ ac. errable in the comon ffieldes.

Richard Hersey hath xv ac. errable in the comon ffields.

John Poore, Ixiij ac. errable wherof iiij ac. lye in seuerall, the reste in comon, one ac. of medow, and iij ac. wood.

Nicholas Canon hath in his occupacon $\mathrm{lxxv}$ ac. errable wherof $\mathrm{xV}$ ac. in seuerall and the reste in comon.

John Poore and Nicholas Canon charged with wheate, iij buh. John Nalder hath xlvj ac. errable wherof vj ac. lye in seuerall, the rest in comon, charged with wheate

\section{Sum of wheate in the tithing of Phernams Deane.} j buh. ij qrters. iiij buh.

\section{The Tything of Lyschinholte. $\dagger$}

" This name is still preserved in "Anker's Farm."

+ The Linchehou, in Esseburne hundred, (the other manors of the hundred were Combe, Essebnrne or Hurstbonme Tarrant, Estune or Crux-Easton, Liveselle or Litchfield, Odecote or Woodcote, and Optone or Upton) of Domesday Book, is nndoubtedly the Lynkehold which Ernulph de Hesding, at Salisbury, on Candlemas Day, 1081, gave to Serlo, the Abbot of Gloncester.

In the thirteenth century, the Abbot of Gloncester held Linkenholt in frankalmoign, under Ralph de Hastings.

In 1290 the Abott of Gloncester's holdings at Lyngeholte and Littleton were valued together at $£ 15$. In 17 Edward III. Lungeholt was valued at 100s.

The patent of King Henry VIII., of 3 Sept., 1541, when he established and endowed the bishopric and cathedral establishment of Gloncester granted to the new dean and his six prebendaries the old abbey holdings of Lynkynholt, Littleton, and Wallop.

The Blakes, related to the "bold Admiral Blake," of Devonshire, were long connected with Combe and Linkenholt. Nicholas Blake, born at Longparish, 1638, was of this family, also the Blakes of Andover. Alderman Blake, of St. Lawrence, Winchester, who died 1727 , bore the sane arms as the Admiral, with a crescent in the chevron for difference. Nicholas Blake Mayor of Plymouth in 1726, was consin to Robert Blake, of Linkenholt. One Nicholas Blake was Mayor of Portsmouth. Ambrose Blake, Ralph Beynham, John Dumner, Henry Complin, were turned ont of their New College fellowhips by the I,oug Parliament. Among Blake's other companions in that expulsion were Gilbert Wither, who was however restored 4 Sept., 1649. 
William Holte hath in his occupacon 150 ac. in the comon ffields, $\mathrm{xV}$ ac. of bushie pasture, iiij ac. of meade ground, $\mathrm{xxx}$ ac. of Copis ground, the wood the Lords, the herbage doth belong to the said William Holte, until the Copis be vij yeare owlde; charged with wheate,

iiij buh.

Richard Gray hath in his occupacon 1 ac. errable in the comon ffieldes, wherof iiij ac. be newly inclosed, and $\mathbf{j}$ ac. medow, charged for this hould and for $\mathrm{j}$ yard land more $w^{\mathrm{ch}}$ he entreth to at Michas next at phernamsdeane with wheat ij buh.

Elizabeth Polinton* hath in her occupacon 1 ac. errable in the comon ffieldes, ij ac. heathie pasture inclosed, and $j$ ac. of meade ground, charged with wheate

Robert Lunden hath in his occupacon xl ac. errable, wherof iij ac. ar new inclosed, and dim. ac. medow, charged with wheat $j$ buh.

Robert Rumbold hath in his occupacon $x x x$ ac. errable in the comon fieldes, $\mathrm{ij}$ ac. bushie pasture, and $\mathrm{j}$ ac. of medow, charged with

Thomas Poore hath in his occupacon $\Sigma x x$ ac. errable in tho comon ffielde, and $\mathrm{ij}$ ac. heathie pasture, and dim. ac. medow, charged $\mathrm{j}$ goose.

Thomas Kempe hath in his occupacon $\mathbf{x x}$ ac. errable in the comon ffielde, and ij ac. of bushie pasture.

Richard White hath in his occupacon $\mathrm{xx}$ ac. errable in the comon ffielde, and ij ac. of heathie pasture.

Katherine Bate hath in her occupacon $x$ ac. of errable in the comon ffielde, and $\mathrm{j}$ ac. dim. bushie pasture.

The parsonage of Linchinholte $\mathrm{xx}$ ac. of gleebe in the comon ffielde, halfe-an-ac. medow, and ij ac. of heathie pasture charged with wheat,

$\mathrm{j}$ buh.

Sum of Wheate in Linchinholte - ix buh.

\section{The Tything of Taxglye. $\dagger$}

* Of the ancient family of Polhampton.

$\dagger$ The unusually seguestered nature of the situation of Tangley, almost amounting to concealment amongst the wild hill-country of North Hants, induced us to make a pilgrimage to this remote village, and to see, as we thonght, its ancient church. After a long climb up the Three-Legged-Cross Hill, the site of a medieval wayside cross, and a more beantiful spot for such a memorial can scarce be imagined, we reached the old-world village of Hurstbourne Tarrant, where the picturesque inn yclept the "George and Dragon," reminds the passing traveller of the coach and other traffic that formerly traversed this now almost deserted highway. From the village there is a very steep hill to climb. On the right is a charming old Georgian house, with a quaint entrance porch of finely cut brickwork, and above is the date "1742." It was here that for many years lived Joseph Blount, a very remarkable man, 
Vincent Smith hath in his occupacon $x l$ ac. in seuerall and xij ac. in comon, and ij ac. in medow, charged with wheat $\mathrm{j}$ buh. John Leache hath in his occupacon xxiij ac. in seuerall, and xij ac. in comon, and ij ac. in medow, charged with wheat $j$ buh.

Thomas Drewlye hath in his occupacon xxxviij ac. errable in seuerall, xvj ac. in comon, and $\mathrm{j}$ ac. in medow, charged with wheat,

j buh.

Richard Corderoy hath in his occupacon $\mathrm{xx}$ ac. errable in seuerall, xij ac. in comon, ij ac. medow, and iij ac. dim. of wood ground, charged with wheate

j buh.

John Hopgood hath in his occupacon $\mathrm{xxx}$ ac. errable in senerall and $\mathrm{xx}$ ac. in comon, $\mathrm{j}$ ac. of medow and $\mathrm{ij}$ ac. wood ground, charged with wheate

j buh.

John Mercer hath in his occupacon xxx ac. errable in seuerall and $\mathrm{xx}$ ac. in comon, $\mathrm{j}$ ac. of medow, and $\mathrm{ij}$ ac. of wood ground, charged with wheate

j buh.

William Coxe hath in his occupacon $\mathrm{xx}$ ac. errable in seuerall, and viij ac. in comon, $\mathrm{j}$ ac. of medow, and iij ac. wood ground.

Christopher Jeffery hath in his occupacon $\mathrm{xV}$ ac. errable in seuerall, vj ac. in comon, ij ac, medow, and iiij ac. of wood ground.

William Mercer hath in his occupacon $\mathrm{xv}$ ac. errable in seuerall and $v j$ ac. in comon, $j$ ac. medow, and iiij ac. of wood ground.

William Leache hath in his occupacon $\mathrm{xv}$ ac. errable in seuerall, vj ac. in comon, and $\mathrm{j}$ ac. dim. in medow.

William Coxe, Christopher Jeffery, William Mercer, William Leache charged with one lambe between these iiij, price iijs. iiijd.

the intimate friend and correspondent of William Cobbett, who records many visits paid to his estimable friend. Mr. Blount was a member of the ancient and distinguished Catholic family of this mame, so long seated at Mapledurham. He married 1st, Jnne, danghter of John Saterthwaite, Esq., of Mansergh Hall, Westmoreland, and 2dly, Anne, only child of Mr. Richard Martin, of Hurstbonme Tarrant, and by this lady he had an ouly daughter. Mr. Blount died in 1863 , in his 84 th year, and together with his father-in-law, and wife, who long pre-deceased hin, dying in 1820 , in her 30 th year, is buried in the chnrchyard of his adopted village. At the top of Hurstbourne Hill is a solitary cottage, where the old toll bar formerly stood. Tangley is, however, one of those spots which, when once reached, would, for those who cared not for the bustle of the world, have especial charms, and the sweet nature of the scenery would be fascinating to those who had once overcome the difliculties of the access, and knew the ups and downs of the return. After so long and rongh a journey it was disappointing to find that the Church, which is described as having been "a sumall antique edifice," had been destroyed, as was the crse with its aister-cluarch of Faccombe, when much that was beautiful and ininitable was rathlessly swept away through ignorance and misplaced zeal. Neither in the Church nor Chnrchyard do any ancient monuments remain, but in the names of Leach, Smith, Mercer, Piper, Poore, etc., wo trace the descendants of ancestors living liere in the Elizabethan are.

In 1535, Sir Richard Reade was then lord of Tangley Manor. 
Robert Crowch hath in his occupacon $\mathrm{x}$ ac. errable in severall, and vj ac. in comon, $\mathbf{j}$ ac. medow, and $v j$ ac. of pasture $j$ pullett. Annis Wibley hath in her occupacon xiij ac. errable in seuerall, and viij ac. in comon, charged with i pullett.

$$
\begin{gathered}
\text { Sum of Wheat paid in the Tything } \\
\text { of Tanglye. }
\end{gathered}
$$

The Tything of UPPer husborne.*

William Crowchman hath in his occupacon xxviij ac. errable in comon, charged with

j henne.

John Purchill hath in his occupacon lviij ac. errable in comon, and $\mathrm{j}$ ac. dim. in meade ground charged with wheate

$\mathrm{j}$ buh.

Reynold Purchill hath in his occupacon xxiiij ac. errable and dim. ac. medow ground.

Simon Irenmonger hath in his occupacon xiij ac. errable in comon. John Whitear hath in his occupacon $\mathrm{lxv}$ ac. errable in comon and iij ac. in medow.

John Bunny + hath in his occupacon lxiii ac. errable and iiij ac. medow.

John Whitear and John Bunnye charged with wheate iij buh. Simon Kempe hath in his occupacon $\mathrm{v}$ ac. errable in comon.

Richard Hersey hath in his occupacon $\mathrm{v}$ ac. errable in comon.

Christopher Rumbold and John Hellier have in there occupacon 120 ac. errable in comon, and $\mathrm{v}$ ac. in medow, charged with wheate

iij buh.

* Upper Hurstbourne or Hurstbonrne Tarrant. The nunnery at Tarrant or Tarent Crayford or Crawford, Dorset, from which the suffix is derived, was a house of Cistercian or White Nuns, called originally "The Charnel," founded by Richard Poore, Bishop of Salisbury, at this place where he was born, and where his heart is interred. There are no ancient monuments remaining in Hurstbourne church, but in the churchyard are many memorials of the Holdways, Poores, Bannings, Blandys, Childs, Mundy, Durnford, Steele, and other worthy old residents in the parish. A mural tablet in the Church commemorates the Rev. Samuel Heskins, or Haskins, for 30 years Rector of Tydworth, and Vicar of Hurstbourne 47 years. He died in 1732. His daughter Mary, married Mr. Samuel Slocock, of Newbury, and is buried in the chancel of the church there. There are also some memorials of the Powletts, one of whom Thomas, youngest son of Lord Charles Powlett, is buried in the chancel, He died 2 Sept., 1708, a. 63.

$t$ The Bnnnys were in possession of an estate at Ibthorp, a tithing of Hurstbourne Tarrant from the time of King John as appears by a deed of that date, and continued to hold property here till recent years. The late Edward Brice Bunny, Banker, of Newbury, was lineally descended from this old stock, and his son Colonel E. J. St. John, of Slinfold, Horsham, Sussex, is the present representative of the family. The Hurstbourne Bunnys were connected by marriage with the Blandys, Vincents, and other old families of good standing in the neighbourhood. 
Robert Tamidge hath in his occupacon 1 ac. errable in comon, and $\mathrm{j}$ ac. dim. in medow charged with wheate $\mathrm{j}$ buh.

Edward Portchmouth hath in his occupacon xxx ac. errable in comon, and $\mathrm{j} \mathrm{dim}$. in medow, charged with $\mathrm{j}$ pullett.

William Milles hath in his occupacon xl ac. errable in comon, and ij ac. medow ground.

William Bulpitt* hath in his occupacon xl ac. errable ground in comon and ij ac. dim. in medow; the said Milles and Bulpitt charged with

halfe a lambe.

Roger Richardson hath in his occupacon xij ac. errable ground in comon.

Robert Longman + hath in his occupacon lij ac. errable ground in comon, and $\mathrm{j}$ ac. dim. medow, charged with wheate $\mathrm{j}$ buh.

William Wallis hath in his occupacon $\mathrm{lx}$ ac. errable ground in comon, and ij ac. in medowe, charged with wheate $j$ buh.

John Hellier, senior, hath in his occupacon xij ac. errable in comon and dim. ac. of meadow.

William ffarr $\ddagger$ hath in his occupacon xxviij ac. errable ground in comon, and $\mathrm{j}$ ac. in medow, charged with

$\mathrm{j}$ henne.

John Canon $\S$ hath in his occupacon $x v$ ac. errable in comon, and dim. ac. of medow.

John Pourchman hath in his occupacon $x$ ac. of errable ground in comon.

Robert Munday hath in his occupacon l $x \times$ ac. errable ground in comon, and iij ac. medow charged with wheate $\mathrm{j}$ buh.

Thomas Hendaye hath in his occupacon $\mathbf{x x x}$ ac. errable in comon, and $\mathrm{j}$ ac. in medow, charged with

James Harte hath in his occupacon xxij ac. errable ground in comon, and $\mathrm{j}$ ac. in medow.

Humfrye Bothe hath in his occupacon $\mathbf{x x x}$ ac. errable in comon, and $\mathrm{j}$ ac. in medow, charged with

j pullett.

- The late William Whitear Bulpitt, Banker of Winchester and Alton, was descended from this family, and the Whitears of the same place. (See Note to Woodhaye).

+ For note respecting the Longman fanily, see Woodhaye.

t The name of Farr is one of long standing at dndover and the neighbourhood.

$\S$ John Canon, i.e. Cannin or Canning, a very ancient family in this district. In his "Saxons in England," Mr. Kemble has collected a list of very nearly 1400 nanes of English parishes ending in ing. Antong such patronymics Mr. Kemble includes the nane of Canning, which niny serve as an illustration and key to the history of nanes. Canning was first a family name improrted into England twelve centuries ago. The foreign settlers who bore it naturally gave it to the place at which they settled. The next stej was, that individuals born in or connected with the plice, distinguished themselves from other Johns or Williams, as John or Willian de Canning, or Cannings. Presently the de fell into disuse, and so the word insensibly passed into a family nane once more. 
Walter Warren hath in his occupacon $\mathrm{xv}$ ac. errable in comon.

Thomas Pescodde hath in his occupacon xij ac. errable in comon and dim. ac. in medow.

Thomas Waterman hath in his occupacon $\mathrm{xxx}$ ac. errable in comon and dim. ac. in medow.

William Skeye hath in his occupacon xxviij ac. errable in comon $\mathrm{j}$ pullett.

John Roase hath in his occupacon xxviij ac. errable in comon and dim. ac. medow, charged with

j pullett.

Robert Genoway hath in his occupacon $\times x \times v j$ ac. errable in comon and $j$ ac. in medow.

Allice Dowce* hath in her occupacon 1 ac. errable in comon, and $\mathrm{j}$ ac. dim. in meadow; the said Robert Genoway and Allice Dowce, charged between them with halfe a lambe.

Thomas Hellyer + of ffaccombe hath in his occupacon xxvj ac. of errable ground in comon.

John Hellyer hath in his occupacon of his ffarme 180 ac. of errable ground, wherof 104 ac. lye in comon, and $\mathrm{l} x$ ac. in senerall, and xvj ac. meade ground, more ouer the Lord Marquis hath in Dowles' $\ddagger$ xij Copses, and the said John Hellyer hath halfe the herbage for vij yeares after the sale therof.

The said John Hellyer hath in his occupacon one Copie hould in Husborne Tarrante conteyning $\mathrm{xxx}$ ac., wherof one of the said acs. is medow, and the rest lyeth in the comon fields.

The said John Hellyer hath in his occupacon of the parsonage in gleebe land $\mathrm{lx}$ ac. errable in common, and iij ac. medow and pasture: the said ffarme and parsonage charged with wheate xij buh.

$$
\begin{gathered}
\text { Sum of Wheate in the Tything } \\
\text { of Upper Husborne. }
\end{gathered}
$$$$
\text { ij qr. vij buh. }
$$

* There is a pedigree of Dowce of "Husborne" entered in the Hants Visitation of 1634. See note to Sloake or Stoke, St. Mary Bourne.

$\dagger$ The family of Hellyer or Hillier was a widely distributed one in North

Hants. There is a pedigree of the family in the Hants Visitation of 1634. The name is still common in the neighbourhood in the form of Hillier, Hilliard, and other varieties.

$\ddagger$ Dowles or Doles Wood. According to Dr. Johnson, Dole means to share a grant, hence the name of this well-known wood, originally part of the great forest of Chnte, may have been derived from its having been divided or shared by the several tenants of the Lord's manor. Dole is also an agricultural word for a void space left in tillage. The "Lord Marquis" referred to was John Paulet, 2nd Earl of Viltshire; and Marquis of Winchester, who died shortly after his more famous father, in 1576. The manor of Hurstbourne Tarrant, at the dissolution of religious houses, was granted with other property in Hampshire to the first Marquis of Winchester for the maintenance of a small garrison at Netley Fort, near Netley Castle, on Sonthampton water, which had then lately been erected as one of the defences of that port. 
The Tything of Conвe. *

Imprimis John Parker hath in his occupacon ij yard lande being $\mathrm{xl}$ ac. seuerall ground wherof $\mathrm{xx}$ ac. are errable, $\mathrm{xviij}$ ac. pasture and vacant ground, and $\mathrm{ij}$ ac. meadow rated at the payment of wheate

$\mathrm{j}$ buh.

George Knight hath in his occupacon $j$ yard land being xviij ac. seuerall ground wherof $x i j$ ac. ar errable, $v$ ac. vacante, and $j$ ac. meadow, rated at

xd. for a lambe.

Thomas Maye hath in his occupacon xx ac. seuerall ground wherof xij ac. ar errable, six acres pasture and barren ground, and $\mathrm{ij}$ ac. meadow, rated at

$x d$. for a lambe.

Robert Pierce hath in his occupacon j yard land wherof xvj ac. ar errable in seuerall and comon, rated at

j pullett.

Henry Hedges hath in his occupacon $j$ yard land being xvj ac. errable ground in seuerall and comon, wherof dim. ac. rated at j pullett.

Simon Smith hath in his occupacon $\mathrm{j}$ yard land dim. being xxij ac. in comon and seuerall wherof $j$ ac. in meadow rated at

xx. for a lambe.

* The three connties of Hants, Berks, and Wilts meet at a point near Combe called Buttermere Corner. Conbe is a very common name for villages, especially on the downs or other ranges of hills. The word is Welsh, and means a particular kind of valley; for all valleys are not combes. The chalk downs above Combe, looking northward over Berkshire, is the highest point of the chalk in this part of England. A little way off is a very extensive ancient British entrenchunent, or hill-fort called Walbury, the altitude of the hills at this place being just a thousand feet above sea level.

In 1084, there was a church on the manor of Combe, when it belonged to Ernulph de Hesding, the Domesday lord of Newbury. Shortly afterwards his wife Amelin gave it to the Abbey of Bec. In the 13th century the Priory of Okeburne held Cumbe by ancient enfeoffment auder Ralph de Hastings in frankalmoign. In 1290 the rectory of Cumbe was valued at $£ 13$ 6s. 8d, and its vicarage at $\$ 4$ 6s. 8d. By the retarns made 2 August, 1294, it appears that the lands held by the Abbey of Bec, or rather by his prior of Okeburne, in his own hands, including a windinill, pasture for 1000 sheep, valued at 4ls. 8d., came to $102 s .8 d$. From 29 customary tenants and seven cottars he received £ll 9s. 9d., making the whole income from Combe £16 12s. 5d. In 1414 at the suppression of Okeburne priory its site and manors were given to the University of Cambridge, and afterwards to the royal foundation of King's College. The tithes and spiritualities were granted to John, Duke of Bedford, for the College of Windsor-a grant confirmed by Henry V. and Edward IV.

It appears from a record of 1512 , that on $18 \mathrm{July}, 1467$ the King gave to the Dean and Canons of Windsor the manor and advowson of Combe, in whon the patronage of the vicarage is still vested. Linkenholt originally belonged to the lord of Combe.

The other alien yriories in Hampshire suppressed or tranferred by the statute of 1414, were, Andewell (Tyrone), Andover (St. Sauveur), Applederwell (St. Mary de Montisburg), Carisbrook (Lyre), Elingham (St. Sauveur le Viconte), Hamele, or Hamble (Tyrone), Hayling (G'ymeges, or Junieges), St. Cross, (Isle of Wight), Tyrone, Selborne and Sherborne (St. Vigor of Ceresy), Stratfield saye (the Valido monte). 


\section{A ROYAL PURVEYANCE IN THE ELIZABETHAN AGE.}

Robert Saunders hath in his occupacon ij yard land dim., being $x l$ ac. errable in comon and seuerall, wherof $j$ ac. medow, rated at wheate j buh. dim.

Agnes Crickland hath in her occupacon $j$ yard land being xvj ac. errable in comon and seuerall and dim. ac. in medow.

Simon More hath in his occupacon $\mathrm{j}$ yard land being $\mathrm{xv}$ ac. errable in seuerall and comon, wherof $\mathrm{j}$ ac. in meadow.

Henry Rumboll hath in his occupacon $j$ yard lande being $x \nabla$ ac. errable ground in seuerall and comon where dim. ac. medow, rated at

Peter Rumboll hath in his occupation $\mathrm{j}$ yard land being $\mathrm{xv}$ ac. errable in seuerall and comon, wherof $j$ ac medow.

Robert Kempe hath in his occupacon $j$ yard land being $x v j$ ac. errable in seuerall and comon, and $j$ ac. meadow rated at

$\mathbf{x d}$. for a lambe.

William Kempe, senior, hath in his occupacon $\mathrm{j}$ yard land dim. being xxij ac. errable in seuerall and comon, wherof dim. ac. medow rated at

$\mathrm{xd}$. for a lambe.

John Blake hath in his occupacon ij yard land dim. being xl ac. errable in seuerall and comon, and $\mathrm{j}$ ac. meadow rated at wheate j buh. dim.

William Kempe, junior, hath in his occupacon $\mathrm{j}$ yard land being xvj ac. seuerall, wherof in errable xij ac. and iiij ac. in pasture.

Anthonye Boswell * hath in his occupacon x yard lands belonging to his ffarme; wherof iij ac. ar medow, lx pasture, and lx ac. ar wood ground, wch ar to the use and occupacon of the Lord, and lxxx ac. of tillage, rated at wheate,

viij buh.

the said Anthony Bosswell hath in his occupacon iij yard lands at Nestweeke, $\dagger$ wherof lvj ac. ar seuerall grounds; $\mathrm{xx}$ ac. ar pasture and barren ground; xxiiij ac. errable, and ij ac. ar meadow, rated at wheate, $\quad j$ buh.

It $m$ the said Anthony Bosswell is rated for his parsonage at wheate j buh. dim.

Sum of Wheate in the Tything of Combe xv buh.

* The Boswells of Combe, probably the ancestors of Johnson's biographer, were the principal landowners in the parish at this time, and farmers of the great tithes.

$t$ Eastwick apparently a clerical error for "Estweeke," as it was then written. 


\section{LIST OF LANDHOLDERS}

FROM THE PRECEDIYG ASSESSMENT FOR PURVEYANCE OF THE ROYAL HOUSEHOLD OF QUEEN ELIZABETH, 1575.

\section{HUNDRED OF EVINGER. *}

WhITChURCH.

Audlye, Richard, Mr., (Colhenlye)

Beanes, Richard

Benham, Henry

Benham, Robert

Boyett, Thomas

Brextone, William

Brooke, Richard, Gent.

Bunny, Thomas, sen.

Buttler, Richard

Clarke, John

Cooper, Edmond

Cooper, Robert

Deane, Simon

Ffoster, Nicholas

Harison, John

Heywood, Nicholas

Howes, John

Lambden, John (Colhenlye)
Long, Thomas, sen,

Penton, Richard

Perry, Thomas

Perry, Richard

Phillips, John

Poynter, John

Poynter, Richard

Poynter, Winifred

Queene, Willinm

Reeve, Simon

Reynolds, William

Rutter, Roger (Charlecott)

Silver, Thomas

Smithe, Robert

Soper, William (Charlecott)

Spencer, John

Wadlow, Nicholas

Wadlow, William (Charlecott)

Webb, Thomas

* There are one or two points connected with these Hampshire Hundreds, on which we nay in passing offer a few remarks. It is often said that we owe the institution of Shires, Tithings, and Hnndreds to Alfred the Great, but these certainly existed long before his time, for they are alluded to in the laws of King Ina, c. A.D. 700. By referring to the list it will be observed that of the five Hnndreds comprised in the Purveyance there are bat two called from the chief town within their limits, viz.: Kingsclere and Overton. Of the rest Evingar, (Evingare of Domesday); Chnteley, (Cillei of Domesday); and Pastrow or Pastroe, all traces have long since perished of the sources from which they were originally derived, and the interpretation seems to point to a remote time when this part of the country was but thinly peopled, and there were but few towns or villnges of any note in it. 
114 A ROYAL PURVEYANCE IN THE ELIZABETHAN AGE.

Frekfolk or Ffreefolke,

Benham, Henry

Benham, Hugh

Benham, Robert

Clarke, Thomas

Cropp, Peter

Cufflye, Richard

Lambert, Walter, Mr.
Mason, Christian

Norris, Henry, Mr.

Paulet, John, Mr.

Roffe, or Roaffe, Andrew

Silver, Joane

Sutton, William

Webbe, Thomas

Hurstbourne Priors, or Down Husborne.
Adams, Elizabeth
Adnam, Thomas
Hunte, Nicholas
Bechen or Beachen, John
Issarne, William
Jaques, William
Billett, John
Blanchard, Richard
Kingsmill, Richard, Esq.
Blanchard, Richard, jun.
Laske, John
Brooker, John
Locke, John
Milles, William
Cooper, John
Edwards, Thomas
Fisher, Thomas
Gawen, Matthew
Godden, William
Goslinge, Richard
Newell, Christian
Newell, Elizabeth
Oxenbregg, Lady
Penton, George
Silvester, Alice
Silvester, William
Goulding, William
Heath, Anthony
Hedges, Richard
Underwood, Richard
Waterman, John
White, Swithine or Swithian
Holland, Morrice
Willkins, Christian

St. Mary-Bourn, or Boornt.

Berkeley, Thomas

Bestocke, Thomas

Braye, John

Brextone, John

Cooper, Simon

Corham, Roger, Mr.

Crooke, Elizabeth

Ilderwill, Hugh
Issarne, William

Lake, Hugh

Laske, William

Poore, Jeffery

Smith, Bartholomew

Smith, John

Underwood Richard

Underwood, Robert 
Bachelor, George

Dowse, Thomas

Elderwill, William

Fficcas, George

Ffines, George

Billet, Elizabeth

Cannon or Canning, Thomas

Cooper, Richard

Hayes, Richard

Barnard, Richard

Brighte, William

Broadway, Bartholomew

Goddard, Christopher

Godden, George
STOKE.

Hayes, William

Leshe, Bowden

Hawkine or Hawkins, Joane

Wigmore, Richard

Woodard, William

WEeke.

Horne, Thomas

Kidgill, William

Oxenbregge, Robert

Watts, Richard

Egberky.

Godden, John

Godwine, Christopher

Kidgell, Thomas

Nowell or Newell, William

Taylor or Taller, Simon

Binley.

Penton, John

Philpot, Nicholas

Poore, Jefferie

Poore, Thomas

Skinner, Christopher

Newell, or Nowell, Thomas

Woodheye or Woonhay (EAst).

Abbington, Thomas

Alexander, John

Androes, Agnes

Angell, William

Ballard, William

Barebon, Elizabeth

Barebon, John

Beckensall, Richard

Durman, John (Sellhouse)

Ffeilder, Ellice

Ffeilder, Richard
Kinge, Thomas

Manfielde, Thomas

Mansill or Mansell, Thomas

Morgan, William

Osgood, Agnes

Parker, John

Parker, Robert

Parker, Simon

Pearman, Elizabeth

Pease, John

Pesse, John 
116 A ROYAL PURVEYANCE IN THE ELIZABETHAN AGE.

Woodheye or Woodhay (East), (Continued).

Fforde, John

Ffrome, Edward

Goddard, Edward, Esq.

Harris, Margery

Harte, William

Hellier, Elizabeth

Hellier, William

Herne, Richard

Hinde, Richard

Houldway, John

Houldway, Richard

Humbard, John

Ironmonger, John
Pinmore, Thomas

Robinson, Thomas

Rumboll, Bartholomew

Rumboll, Drewe

Rumboll, Edward

Rumboll or Rumbold, William

Stelle or Steile, William

Young, John

Walter, Thomas

Welles, Bartholomew

Wheeler, Richard

Whitear, John

Wholdaye or Holdway, John

ECCHENSWELL OR ITCHENSWELL.

Awforde or Alfforde Walter

Benam or Benham, John

Bever, Richard

Bolle, Agnes

Ffosbury, John

Ffrancklin, Ingram

Ffrancklin, Thomas

Legatt, John

Morrice, Richard

Prixmall or Prismall, William

Reynolde, John

Reynolde, William.

Rowland, Peter

Rumboll, John

Southe, Richard

Spencer, Walter
Swithine, Richard

Wall, Francis

Whetlande, Nicholas

White, John

White, Richard

White, William

Winckworthe, Edmonde

Winckworthe, John, sen.

Winckworth, John, jun.

Winckworthe, Pawle

Wither or Withers, Edward

Wither, Henry

Younge, Alice

Younge, Joan

Younge, John

Ashmansworth.

Bachelor, John

Cole or Coll, John

Cole, Joane

Hellier, Thomas

Holdwaye, Alice

Holdwaye, Joane
Lange, Peter

Neale, John

Penton, Thomas

Stevens, Amye

Stephens, Ann

Thurman, Agnes 
Ashyansworth, (Continued).

Holdwaye, John Thurman, John

Holdwaye or Wholdaye, Nicholas Walter, John

Holdwaye, Thomas

Westcott, Arthur

Holdwaye, Walter

Highclere and Hawclerr.

Alle, John

Beanes, Anthony

Beckinsall, Robert

Comen or Comyn, Philip

Cooper, Morrice

Ffolwell, William

Ffrome, Edward

Ffrome, John

Ffrome, William

Greene, John

Gunter, Mr.

Honiwell, John
Kingsmill, Richard, Esq.

Knight, Richard, Mr.

Lovinge, Peter

Lovinge, Roger

Prixmall or Prissmall, Alice

Sawyer, John

Still, William

Waterman, Poter

White, William

Younge, John

Younge, William

Burghclere or Borrowclert.

Acwell or Atwell, John

Alle, John

Alle, Philip

Alle Thomas

Arundell, Ellinor

Arundell, John

Arundell, William

Beckensall, John

Brooke, Richard

Bronsdowne, John

Clarke or Clerke, John

Cleeve, William

Cooper, Agnes

Crooke, Richard

Deacon or Dickon, Joane

Dickon, John

Ffolwell or Ffollowell,'William

Garraway, John

Gaston, John

Herryett, John
Hould, Peter

Lee A. John

Lee A. Philip

Lee, A. Thomas

Nutkine or Nuskine, John

Oliver, John

Peirce, Agnes

Peirce, John

Potter, .......

Steptoe, John

Torroway, John

Wendbolte, Simon

Wheeler, John, sen.

Wheeler, John, jun.

Wheeler, Richard

White, John

Withers, William

Yeeles or Eeles, Simon

Yeeles, William 
118 A ROYAl PURVEYANCE IN THE ElizabethaN AgE.

Baghurst or Baughurst.

Baghurste, William

Bye, William

Deane, William

Dicker or Dyker, William

Drake, William

Ffreeborn, Hugh

Ffreeborn, John

Ffreeborn, William

Greene, Robert

Harmsworthe, Thomas

Benham, Walter

Harman, John

Hellyer,

Holdway, John

Holdway, Nicholas

Marshall, Richard
Losse, Richard

Marshe or Mershe, John

Nott, Thomas

Pevicke, Thomas

Potter, Nicholas

Seward, William

Spencer, John

Sweetapple, William

Withers, Richard

NewTowne:

Meare, William

Pierce, John

Smith,

Stanbrooke, William

Webbe,

White, John

\section{HUNDRED OF CHUTLYE.}

Monk-Sherborne.

Bushell, Anthony

Cooper, Thomas

Dowman, John

Ffroglie, Alexander

Harnewood, William

Harris, Katherine

Hasker, or Haskar, John

Hasker, William

Hawkine, Agnes

Hawkine, Joane

Hawkine, Richard

Holmes, John

Pickmonde, Richard

Gardner, John

Lardner, Widow

Snowe, Anthony

Stanbrooke, John
Pincke, Edmonde

Pincke, Richard (Priory)

Rive, Richard

Russell, Thomas

Sherwood, Joane

South, James

South, John

Touvye, or Tovye, Clement

Trewe, James

Voaxe, Thomas

Woode, John

Warham, or Wareham, Thomas

Wickens, Francis

Wortinge.

Starke, Thomas

Trewe, Thomas

Whitehorne, Widow 
Lawrexce-Wotton.

Ailiffe, Thomas

Ailiffe, William

Browne, John

Browne, Richard

Burnell, Ideth

Buttler, Robert

Carter, Margaret

Ffreemantle, Richard

Hacke, Richard

Hacke, Robert

Hall, Richard

Knight, John

Lee A. Thomas

Mortimer, John

Parker, Widow

Apleton, John

Dicker, Margery

Drewett, Richard

Drewett, Thomas

Gedge, Michell

Hall, Jane

Harris, Richard

Hinwood, John
Poynder, Humfrye

Prymer, or Primmer, John

Rabnett, Thomas

Randall, William

Simpson, Alice

Small, Agnes

Small, Richard

Soper, John

Spencer, Hugh

Warham or Wareham, Mawde

White, Joane

Wither, John

Wither, Richard

Wissam, John

Hanington.

Primer, or Primmer, Philip

Soper, William

Upton, George

Wareham, or Warham, Elioner

Wareham, or Warham, Thomas

Wither, Joane

Wither, Nicholas

Church OAKrey.

Ayliffe, Humfrie

Ayliffe, William, jun.

Wareham, or Warham, Lady,

Kingsmill, Sir William, knt., Wigge, William

(Malshanger)

Winckworth, Richard

Smith, Darye

\section{HUNDRED OF KINGSCLERE.}

Earistone.

Cooke, Edmonde

Ffolwell, William

Hunte, James

Leggatt, John

Massone, or Mason, George
Mason, James

Palmer, John

Withers, Edward

Withers, Margaret

Withers, William 
EDMonstrop Launcelewili.

Knight, Nicholas

Reynold, John

Knight, Walter

Spencer, Walter

Love Locke, or Lovelocke, John Wigmore, Nicholas

Edmonstrop Beenam or Begnham.

Bachelor, Ingram

Bachelor, John

Becher, Vahan or Vaughan

Buttler, Margaret

Chamberlein, John

Hunte, James (Appshanger)

Laurence, John
Mace, Walter

Mason, Robert

Millett, Nicholas

Wayte, Thomas

Wayte, Richard

Withers, Henry

Frroberrye, or Frobury.

Apulton, Thomas

Camber, John

Deane, William

Edwards, Thomas

Gouldinge, William

Hunte, George

Hunte, James

Knighte, Richard
Merryett, William

Prior, Walter

Smith, Henry

Spackman, William

Spencer, Thomas

Strike, John

Wrenne, Richard

Kingsclere Lordship.

Aberye, Edward

Allen, Michael

Attfield, Elizabeth

Attfleld, John

Bachelor, Ingram

Bachelor, Robert

Bachelor, Thomas

Bye, John, gent.

Collman, Richard

Cooper, Robert

Currant, Anthony

Dicker, Walter

Earlye, John

Edwardes, Thomas

Ffalkner, Peter, gent.
Hunte, John

Hunte, Peter

Knight, James

Knight, Nicholas

Knight, Peter

Knight, Stephen

Legatt, Thomas

Longe, William

Mason, Robert

Maye, or Meye, Thomas

Merryett, William

Parr, John

Sherland, Edmund

Stacie, John

Spencer, John 
Kingsclere Lordship (Continued).

Ffrowde, Nicholas

Gardner, Thomas

Golding, William

Hawkines, Thomas

Hide, John

Hinde, William, sen.

Hinwood, John

Holdip, James

Holdip, Simon

Hunte, George

Hunte, James (Cannon Courte)
Spencer, Thomas

Spencer, William

Strike, John

Warham, Robert

Wayte, John

Wayte, Richard

Wayte, Thomas

Willis, John

Willmott, Walter

Wrenne, Ingram

Kingsclere Parsonage.

Bachelor, John

Chamberlein, John

Coxhead, Tristram

Hunte, William
Knight, Peter

Knight, Stephen (Parsonage)

Pettye, Thomas

Smythe, Henry

Kingsclere-The Guildable.

The Crown Inn in the occupation of Nicholas Clapham.

Hanington Launcelewell or Launces.

Brewer, Edward

Thorne, Peter

Kingsmill, Henry, Esq. Tyler, alias Fletcher, John

SANDFORD.

A Berrye or Aberry, Edward Hunte, Isabell Appleton, John

Cursell, John

Hunte, James

Dyer, Thomas

Ilsley, William

Dyer, William

Isarne, Hugh

Earlye, Thomas

Mason, John

Fficcas, Nicholas

Osmonde, William

Fforde, James

Parr, Thomas

Purdue, Robert

Ffrowde, Amye

Spackman, William

Ffroude, Anne

Hogge, Thomas

Wareham or Warham, Robert

Hunte, Elizabeth

Weste, Thomas

Willmot, Ingram 
Edwardes, Thomas

\section{Clere Woodcott.}

Hunte, James

Spencer, William

Knight, Nicholas

Webbe, Richard

\section{Ewhurste.}

Ailiffe or Ayliffe, Richard

Wollferton OR WOLVERTON.

Butler, John

Butler, Margaret

Gardner, Thomas

Gedge, Robert

Heron, Robert

Humber, John

Hunte, George
Keene, Hugh

Maye or Meye, Thomas

Prior, Thomas

Silvester, William

Smith, Alexander

Style or Stile, Laurence

Spencer, William

Sydmonntaine, Sydmanton, or Sydmonton, and Litchfield.

Boyer, Henry

Dancastle, Stephen

Diker, Walter

Harding, John

Joyse, John

King, Richard

Kingsmill, Sir Wm., knt.

Knowle, John

Martine, William

Mason, Edmond

Mason, Little John

Mason, Robert
Mason, Thomas

Nutt, Alice

Millett, John

Rowland, Richard

Salter, Walter

Sutton, Walter

Sanders, William

Smith, Thomas

Turton, John

Wallis, $J_{0 h n}$

Wallis, Richard

Weyer, Henry

Okelye or OAkLey (North).

Ailiffe or Ayliffe, Richard

Butler, John, (Pytt ground)

Hellier, William

Knight, John (Tydgrove)

Knight, John (Wackeridge)
Payse,

Smithe, William

Soper, William

Warham or Wareham, Thomas

(Boldsoms or Bollsoms)

John Bachelor

Platstowe. 
COMPOSITION.

HUNDRED OF PASTROE.

Crooxeaston or Cruxeaston.

Parker, Thomas

Temple, William (Parsonage)

Faccombe.

Boswell, Anthony

Brooker, Ambrose

Hellyer, Mawde

Hellyer, Thomas

Bulpitt, Agnes

Lake, William

Bulpitt, Thomas

Lovelocke or Livelocke, Rowland

Bulpitt, Valentine

Pierce, John

Bunney or Bunny, John

Pierce, Thomas

Cole, John

Cooper, John

Reade, Mr. (Manor)

Sandes, Lord

Cumen or Cumming, John

Sweetwell, Mr.

Deane, William

Wadlowe, Robt.

Goodall or Goodale, John

Wigmore, Richard

Hillyer or Hellier, Agnes

LyNCHENhOLTE OR LiNKENHOLT.

Bate, Katherine

Graye, Richard

Holte, William

Kempe, Thomas

Luneden or Lundon, Robert
Pullhamptine or Pollhampton, Elizabeth

Poore, Thomas

Rumboll, Robert

White, Richard

Conholte.

Ffar, Ffarr or Phare, William Page, John

Hellyer, Thomas

Piper, John

Hellyer, William

Wilcoxe, Alice

WOODCOTT-UPPER WOODCOTE.

Dewman, Richard

Follow, John

Hedges, John

Kente, Robert

Kente, Richard

Kingsmill, Sir William
Rumboll, Drew

Still, Simon

Still, William

Taylor, Thomas

Winckworth, Edmond 
124 A ROYAl PURVEYANCE IN THE ElizabethaN Age,

Ffarenham-Deane, Phernams Deane, or Vernham-Deane.

Anker, Robert

Barrett, William

Bennett, Edith or Ideth

Blissett, William

Brooker or Broker, Thomas

Burley, Mr.

Canon or Canning, Nicholas

Castlegate, John

Dewman, Rowland

Ffellow, John

Hedges, John

Hellyer, Thomas

Hersey, Richard
Hopgood, Thomas

Hunte, Richard

Isgate, John

Lovelocke or Livelocke, John

Lovelocke or Livelocke, Thomas

Nalder, John

North, John

Pike, William

Poore, John

Rogers, Thomas

Swaite, Thomas

Tayler, Thomas

Woolridge or Woldridge, Thomas

UpP-HUSBorne or HURstbourne-Tarrant.

Bothe or Booth, Humfry

Bulpitt, William

Bunney or Bunny, John

Canon or Canning, John

Crouchman, William

Ffarr, William

Harte, James

Hellyer, John (Parsonage)

Hellyer, John, jun.

Hellyer, Thomas

Hendy or Hendaye, Thomas

Hersey, Richard

Ironmonger, Simon

Jeneway or Genoway, Robert

Longman, Robert
Milles, William

Munday, Robert

Pescodde, Thomas

Portchmouth, Edward

Pourchman, John

Purchell or Purchill, John

Richardson, Roger

Rose, or Roase, John

Rumboll, Christopher

Skeye, John

Talmage or Tamidge, Robert

Walleys or Wallis, William

Warren, Walter

Waterman, Thomas

Whitear, John

\section{Tangley.}

Corderry or Corderoy, Richard

Coxe, William

Crouch, Robert

Drewlye, Thomas

Hapgood or Hopgood, John

Heathe, John

Jeffery, Christopher

Leache, John

Leache, William

Mercer, John

Mercer, William

Smith, Vincent

Wibley, Agnes or Annis 
Blake, John

Сомве.

Boswill or Boswell, Anthony (Parsonage)

Crickland, Agnes

Maye, Thomas

Hedges, Henry

Kempe, Robert

Kempe, William, sen.

Kempe, William, jun.

Knight, George

More, Simon

Parker, John

Pierce, Robert

Pierce, William

Rumboll, Henry

Rumboll, Peter

Saunders, Robert

Smith, Simon

\section{HUNDRED OF OVERTON.}

Broadlye now Bradley.

Adames, Andrew

Newman, John

Camis, Elizabeth

Ffinden, William

Pryor, George

Fforder, Thomas

Sarage, Sir John, knt.

Cold Waltham, now North Walthan.

Bigges, Edward

Bigges, John,

Bigges, John, jun.

Lamboll, Thomas

Purchase, Julian

Rumboll, James

Brickleden or Brigilton, Richard Searle, William

Clapshowe or Clapshawe, Widow Silver, Mawde

Cobbe, Gilbert

Twyne or Twine, John

Gedge, Rowland

Warham or Wareham, Mawde

Hughes, Robert

Lamboll or Lambold, James

Woodman, John

Deane.

Basse, John

Butler, William

Ffines, Richard, Armiger

Garrett, Baldwine

Garrett, William

Harris, Thomas

Parsons, William

Rogers, William

Roneger, William

Small, Richard

Small, William

Winokworth, Richard

Quidhamton.

Denby, William

Ffisher, Richard, gent.

Hunte, William

Prlmos, Francis, gent. 
126 A ROYAL PURVEYANCE IN THE ELIZABETHAN AGE.

Gardner, Thomas

Ayliffe, William

Berry, Margery

Browne, James

Edmonde, Richard

Goodall, Edmond

Goodall, Simon
AsHe.

Pile, Richard, gent.

Polmampton.

Hunte, Roger, Nutsell now Nutley

Hunte, William, ditto

Knight, George

Oulding or Holding, George

Trewlove, John

Southanton or Southington.

Denbye, Richard

Ffinkley, Rose

Ffrancis, Henry

Ffisher, John, gent.

Ffrancklin, John

Gedge, John
Goodall, Thomas

Harte, Nicholas

Horne, Joane

Nashe, Philip

Palmes, Richard, gent.

NorRINGTON OR NoRTHINTON.

Rumboll, Wadlowe

LAVERSTOCKE.

Cuffly, Walter

Davy, Thomas

Gilbert, John

Heywood, Edward

Luke, William

Mason, Christian

Apelton, William

Coles, Richard

Duffin, Hugh

Hanington, Reynold

Lawnclett, Widow

Ludlow, George, Esq.

Pilgrim, Ralfe

Dowse, John

Ffrancis, Henry, gent.

Matthew, Gregory

Mitchell, George

Penton, Thomas

Sutton, Henry

Toply, Richard

Wadlow, Hugh

Tadley.

Prior, Henry

Prior, Henry, jun.

Prior, Thomas

Sheffield, Richard

Shorland or Shoreland, Richard

Still, Robert

Wither, Richard

Overton.

Ffisher, John, gent.

Lancaster, William

Magewicke, John 


\section{GENERAL INDEX.}

A Berry, Edward, 41, 42, 62, 66

Abbington, Thomas, 89

Acwell or Atwell, John, 29, 97

Adames, Andrew. 68

Elizabeth, 80

Ailiffe, George, 74

," Humfrey, 34

, Richard, 39, 41, 60, 66

"Thomas, 33, 35

William, 33, 34, 35, 51, 54

,, William, jun., 36

70,74

"Family, 60

Albans, St., 3

A Lee or Alle, John, 27, 94, 96

, $\quad$ Philip, 28, 97

, Thomas, 29, 33

Alexander, John, 30, 89

Alien priories in Hants, 111

Allen, Michael, 65

Alsopp, Widow, 37

Alton, 16

Ambrose, Admiral, 38

Andewell, priory of, 111

Andover, 100, 111

Andrews, Richard, 22, 78

Androes, Agnes, 30, 89

Angell, John, 25, 31, 86, 89

Anker, Robert, 46, 105

Applederwell, or Appuldurcombc, priory of, 111

Apleton or Apulton, John, 37, 44,

61,63

", " $\quad$ "William, 53, 73

Apshanger Farm, 38

Articles of Agreement between the Board of Green Cloth and the Jnstices of Hants, 15-19

Arandell, Elinor, 28, 97

, John, 29, 96

Ashe, 51, 53, 69

$$
\text { Family, } 96
$$

Landholders at 126

Ashley, Edmund, 72

Ashmansworth, 26, 29, 31, 91, 92, 93

Athelstan, King, 26, 92

Landholders at, 116, 117

Atkins, Thomas, Esq., 71

Attfielde, Elizabeth, 42

, Joln, 42, 63
Audley, James, Lord, 99 , Mr. Richard, 22, 77

"Sir John, 77

Awforde, or Alforde, Walter, 32, 91

Aylesbury, William of, 2

Bachelor, George, 28, 83

, Ingram, 41, 42, 65

, John, 26, 43, 44, 67, 92

, Robert, 42, 65

,"Thomas, 42, 65

Bacon, Sir Francis, 5

Baghurst, or Banghurst, 27, 99

$$
\text { ", " Iaudholders }
$$

Ingram, 31, 98

Ballard, William, 30,89

Barebon, Elizabeth, 30, 88

, John, 30, 89

" "Praise God " 88

Barnard, Richard, 25, 85

Baron, Court, 9

Barrett, IVilliam, 105

Basing Honse, 40, 71

Basingstoke, 16

Basse, John, 54, 69

Bate, Katherine, 106

Baylie, Kobert, 37

Baynton or Beynton, Robert, 24

Beachen, John, 28, 30

Beanes, Anthony, 94

," Richard, 22, 76

Beauchamp, Edward, Lord, 25

Bec, Abbey of, 47, 111

Becher, Vahan, 38

Bedford, William, Dake of, 72

Beenham Court, 38

Beconsall, or Beconshaw, John, 26,

$$
27,95
$$

$\begin{array}{llr}\text {, } & \text { " } & \text { Richard, } 26, \\ & & 88,89 \\ \text {, } & \text { " } & \text { Robert, } 27,94\end{array}$

", $\quad$ ", $\quad$ Wobert, 27,

", " " Sir White, 95

Benham, Henry, "30, 79

William, 95

" Hagh, 23, 78

"John, 32

Robert, 30, 79

IValter, 29, 86

Bennett, Edith or Ideth, 47, 104 
Berklye, Thomas, 23

Berry, Margery, 54, 70

Bestocke, Thomas, 82

Bever, Richard, 32, 90

Bigges, Edward, 50, 69

, John, 50, 54, 69

, John, jun., 69

Billett, Elizabeth, 83

, John, 28, 80

Binley, 25, 28, 85, 86

, Landholders at, 115

Blake, Admiral, 105

" Family, 105

"John, 47, 112

Blanchard, Richard, 28, 80

Blandy, family," 51 , jun., 80

Richard, 51

Blissett, William, 49, 104

Blount, Joseph, 106, 107

Blunden, Madame, 70

Bollsoms farm, 66

Bolton, Charles, Duke of, 40

Borhante, Sir John de, 49

Borne or St. Mary Bourne, 23, 24, 28

Borrowclere, or Burghelere, 27, 28, 95,

96,97

"

,

Landholders

Boswell, Anthony, 22, 47, 102, 112

Both or Booth, Humfrey, 49, 109

Boyer, Henry, 56 ," family, 56

Boyett, or Bowyett, Thomas, 22, 76 "John, 28, 23, 78, 81

Bray, Sir Reginald, 22, 78

Brexton, John, 23, 81

, William, 76, 77

Brickledon, or Brigilton, Richard, 50, 69

Brighte, William, 25, 85

Broadlye, or Bradley, 49, 50, 52

" ", Landholders at, 125

Broadway, Bartholomew, 25, 85

Brocas, Sir Bernard, 49 William, 49, 77

Brooke, Richard, 22, 29, 74, 75, 76, 97

Brooker, Ambrose, 47, 102

, John, 28, 80

, Thomas, 47, 104

Bronsdowne, John, 96

Browne, James, 51, 70

, John, 35

" Richard, 36

Balpitt, Agnes, 102

, Thomas, 45, 101

., Valentine, 45, 101

"William, 47, 109

"William Whitear, 109

Bunney, or Bunny, John, 45, 46,

," , Thomas, 78

Bunney or Bunny, family, 108

Burley, Mr., 103, 104

" family, 103

Burnell, Ideth, 37

Burrows, Prof. Montaga, 50

Bushell, Anthony, 37

Buttler, or Butler, John, 39, 40, 60, 66 , , Margaret, 41, 43,61

", ", Richard, 76

, , Robert, 36

" "Willian, 70

Bye, John, gent., 42, 64, 73

,"William, 31,98

Camber, John, 42, 57, 62

Camis, Elizabeth, 68

Canon, or Cannin, family, 109

, " John, 109

", ", Nicholas, 46, 105

" " Thomas, 83

Canon Courte, Kingsclere, 40, 63

Carey, Catherine, 15

Carisbrook, priory at, 111

Carlton, East, 2

Carter, Margaret, 36

Castlegate, John, 46

Cavan, Earl of, 78

Chamberlain, John, 41, 44, 67

Chamberhouse, Thatcham, 74

Chandler, Thomas, 70

Chapman's Ford, 13

Charlecott, 77

Charles I., 5. 6, (at Kingrsclere) 39, 62, (at Whitcharch) 75, 95

Chawton, near Alton, Knight family of, 93

Cheapside, pillory at, 5

Child family, 108

Chilton Candover, 72

Church Oakley, 34, 36, 40

Landholders at, 119

Chutlye Handred, 33-38

"' "' Landholders in, 118 ,

Clapshawe, Widow, 50, 69 [119

Clarke, John, 22, 28, 74, 97 ," Thomas, 23, 78

Cleeve, William, 27, 95, 96

Clere Woodcott, 38, 41, 122

Cobbe, Gilbert, 50, 69 Peter, 70

Cobbett, William, 107

Col or Cold Henley, 22, 77, $78 \quad[69$

Cold or North Waltham, 10,50, 54, 68,

Cole," Joane, 29

Landholders at, 125

John, 26, 29, 91, 92, 102

Coles, Richard, 73

Collman, Richard, 65

Conholte, 45, 103

Landholders at, 123

Cooke, Edmond, 38, 56

Coombe, or Combe, 47, 48, 49, 111, 112

, Landholders at, 125 
Cooper, Agnes, 29, 96

" Ednrond, 76

"John, 23, 47, 80, 102

, Morrice, 27, 94

" Richard, 83

, Robert, 22, 64, 76

, Simon, 23, 81

Thomas, 35

Corderry, Richard, 47, 107

Corham, Mr. Roger, 23, 70, 81

Corse, or Corsey, 16

Corsett, or Cossett land, 77

Coxe, William, 48, 107

Coxhead, Tristram, 41, 67

Crane, Anthony, 19

Creslow, Crown pastares, 5

Crickland, Agnes, 112

Crofte, Sir James, 15, 19

Cromwell, Oliver, 87, 95

Crooke, Elizabeth, 23, 82 ., Richard, 29, 97

Crookham, manor of, 93

Crooxeaston or Crux Easton, 45, 95, 99

Cropp, Peter, 23, 78 Landholders at 123

Crouch, Robert, 49, 108

Crouchman, Willian, 48, 108

Cuftlye, Richard, 23, 78 Walter, 73

Camen or Comyn, John, 102

Currant, Anthony, 65 Philip, 27, 94

Carsell, John, 62

Dancastle, family, 57

," Stephen, 57

Davy, Thomas, 53, 73

Dawman, John, 35

Deacon, Joane, 29

Deane, 51, 53, 54, 69

, Landholders at 125

" Sir Janies, 51

, Simon, 22

$[98,102$

Delaware, Lord, 18

Denby or Dembye, Richard, 52, 72

", William, 51, 70

Deptford, Crown pastures at, 5

Dewman, Rowland, 48, 104

Dicker or Diker, Margery, 34

" ", Walter, 43, 64

Dickon, Joane, 97

William, 31, 98

Digby, Sir Kenelm, 50

Doles Wood, 110

Domesday Hundreds, 113

Dorchester, 5

Dowce, Alice, 47, 110
Francis, 70
"John, 55, 74
, Patience, 64
"Thomas, 28, 82
, family, 82

Downe, Richard, 28, 85

Drake, William, 27

Drewe, Rumboll, 30

Drewett, Thomas, 34, 36

, Richard, 34

Drewlye, Thomas, 47, 107

Dablin, St. Patrick's Cathedral, 18

Daffin, Hagh, 74

Donley, 25

Dorman, John, 30, 89

Dyer, Alexander, 21

, George, 28, 8'

,Thornas, 43, 62

William, 62

Dymoke, Sir Edward, 100

, Francis, 100

Earlstone, 38, 4l, 55

Earlye, John, 64 Landholders at, 119 , Thomas, 41, 61

Ecchinswell, 26, 32, 90, 91, 116

Edmonde or Edmonds, Richard, 54, 70

Edmonstrop Beenham, 38, 41, 43, 44

$$
\text { , Landholders at, } 120
$$$$
\text { "I Launcewell, } 38,41,43
$$

" , Landholders at, 120

Edwardes, Thomas, 44, 64, 80

Eeles, Simion, 96

, William, 96

Egbary, tithing of, 24, 25, 85, 115

Elderwill, Thomas, 83

$$
\text { " Willian, 24, } 82
$$

Elingham, priory of, 111

Elizabeth, Queen, 4, 9, 15, 71

Enclosare Acts, 14

England, Knight Champion of, 100.

Evenger Hundred, 22, 32, 74-98

Ewhurste, 39, 41, 60

Landholders in, 113.118

," Landholder at 122

Eystons of Hendred, 57

F faccombe, 45, 47, 48, 100, 101, 102 Landholders at 123

Ffalckoner, Fanconer, or Falconer, Peter, 40, 63

Ffar, William, 45, 48, 109

Ffarneham Deane, or Vernham Deane $46,47,49,103,104,124$

Ffeilde, Ellice, 30, 89

Fellow, John, 48, 105

liccas, George, 24

Nicholas, 44, 61

Ffielder, J., Esq., 93

, Richard, 89

" family, 89, 90

Ffines, George, 82

, Richard, 70

family, 82

Finden, William, 53, 68

Finkelye, Iose, 54, 72 
Fisher, James, 72

, John, gent., 52, 53, 72

" Thomas, 23, 79

" family, 72

Fleetwood, Sir William, 78

F folwell, William, 27, 38, 94, 96

Fforde, James, 43, 61 John, 89

Fforder, Thomas, 68

Ffortescne, Mr. 72

Ffosberrye, John, 32, 91

Foster, Nicholas, 22, 76

Franchises, the, or "Frenches," 83

Francis, Henry, gent., 52, 71

Ffrancklin, Ingram, 32, 90

$$
\text { " John, 53, 71, } 72
$$$$
\text { ", Thomas, } 32,90
$$

Ffreeborn, Hugh, 31

, John, 98

, William, 98

Freefolk, 23, 78, 79

$$
\text { " Landholders at, } 114
$$

Ffreemantle, Richard, 33

Frith, Farm, 64

Frobary, 39, 42, 44, 62

$$
\text { Landholders at, } 120
$$

Ffroglye, Alexander, 35

Ffrome, Edward, 27, 88, 94

" John, 94

"William, 31, 94

Ffroude, Amy, 41

, Anne, 62

", Nicholas, 42, 66

Fuller, Nicholas, 74

Gardner, John, 35

," Thomas, 39, 51, 53, 60, 65

Garraway, John, 29

Garrett, Baldwine, 54

, William, 54

Gaston, John, 96

Gates, Sir John, 23, 24, 25

Gawen, Matthew, 80

Gedge, John, 52, 60, 72

," Michell, 38

", Robert, 44, 60

, Rowland, 50, 69

Genoway or Jeneway, Robert, 47, 110

Geynes, William, 25, 85

Gilbert, John, 54, 73

Gloucester, Serlo, Abbot of, 105

Goddard, Christian, 85

Godd̉en, George, 25, 85

John, 85

William, 80

Goddwine, Christopher, 25

Goldsmith's Deserted Village, 11

Goodall or Goodale, Edinonde, 70

$\begin{array}{ccc}\text {," } & \text { John, 45, 101, } 102 \\ \text {," } & \text { Simon, 54 } \\ \text { ", Thomas, } 72 \\ \text { Gilliam, 28, 44, } 64\end{array}$

Goslinge, Richard, 23, 80

Gray, Richard, 45, 106

Greene, John, 31, 94

," Robert, 31, 98

Gunter, Mr., 27, 94

Hacke, Richard, 37

Robert, 36

Hall, Jane, 37

," Richard, 36

Hamele or Hamble, priory, 111

Hanington, 34, 36, 37, 38

, Landholders at, 119

", Lanncelewell, 39

, $\quad$ Rejnold, 52, 53, 73

family, 73

Hard’ing or Hardinge, John, 42, 56

Harman, John, 86

Harmsworth, Thomas, 31, 98

Harnewood, William, 35

Harris, Katherine, $\mathbf{3 5}$

, Margery, 30, 89

" Richard, 37

" Thomas, 70

Harison, John, 76

Harrison, Sir Pichard, 19

Harte, James, 109

, Nicholas, 54, 72

,, William, 88

Harwood, John, Esq., 51

Haskar or Hasker, John, 33, 35, 51

Hawkines, Agnes, 35

William, 35, 37

, Joan, 28, 33, 83

, Richard, 35, 37

"Thomas, 42, 65

Hayes, William, 24, 82

" Richard, 24, 83

Hayling, priory, 111

"Hayned," old English word, 9

Heath, Anthony, 28, 80

John, 46

Hed'ger, Robert, 28

Hedges, Henry, 49, 111

John, 48, 105

Hellier or Hellyer, Agnis, 45, 101

$$
\begin{aligned}
& \text {, , Elizabeth, 30, } 89 \\
& \text { " ", John, 22, 46, 100, }
\end{aligned}
$$

Henley, Col. or Cold, 22, 77, 78

Hendy, Thomas, 48, 109

Herne, Richard, 30, 89

Heron, Robert, 39, 60

Herryett, John, 27, 96

Hersey, Richard, 105, 108

Hesding, Ernalph de, 105, 111

Heskin's or Haskins, Rev. S., 108

Heywood or Hayward, Edward, 53, 
Heywood or Hayward, Nicholas, 76

Hide, John, 42, 65 $[79,93,94$

Highclere and Hawclere, 26, 27, 31, , Landholders at, 117

High" Constables" of Hants, precept to, 20,21

Hinde, Richard, 31

"William, sen. and jun., 31

Hinwood, John, 36, 37, 40, 63, 67

Hodnell, Stephen, 71

Hodgson, Rev. J. H., 1

Hogge, Thomas, 41, 61

Holding or Oulding, George, 54

Holdip, Andrew, 74

"James, 64

, Simon, 43, 64, 74

Holland, Morrice, 28, 80

Holmes, John, 35

Holte, William, 45, 106

Honywell, John, 31, 94

Hopgood, John, 47, 107

Horne, Joane, 72

$$
\text { Thomas, } 104
$$

, Robert, Bishop, 18

, Thomas, 28, 85

Hould, Peter, 97

Houldway, Alice, 26, 92

, Joane, 92

" John, 29, 30, 86, 88

" Nicholas, 26, 86

", Richard, 30,88

", Thomas, 29, 92

"Walter, 31, 93

family, 88

Howse, John, 29, 64, 76

Hughes, Robert, 54, 69

Humbard, John, 89

Humber, John, 41, 60, 61

Hnnte, Elizabeth, 39

, George, 39, 61, 62, 65

"J James, 38, 39, 40, 41, 56, 61

"John, 65, 70

"Nicholas, 80

, Peter, 64

"Iichard, 46, 104

" Robert, 51

" Roger, 53

William, 42, 67, 70, 71

Hurst, Monument in Charch, 19

Hurstbonrne Priors, 23, 28, 79, 80

" " ' Landholders at, 114

Harstboarne 'Tarrant, 46, 47, 48, 49, $106,108,109,110$

" ,

Landholders at, 124

Ilderwill, Hugh, 28

Ilslye, William, 62

Ironmonger, John, 88, 108

Isgate, John, 104

Isle of Wight, Trenty of, 6

Issarne, Hugh, 61

William, 28, $80 \quad[91,116$
Itchenswell or Ecchinswell, 26, 32,90,
Jaques, William, 23

Jeffery, Christopher, 48, 107

Jeneway or Genoway, Robert, 47, 110

Josye, John, 57

Keene, Hugh, 39, 60

Kempe, Richard, 99

," Robert, 48, 106, 112

" Simon, 108

, Thomas, 106

, William, 112

"William, jun., 112

Kempshott, 35

Kente, Robert, 48, 99

Kidgell, Christopher, 25, 85

"Thomas, 25, 76, 85

,William, 28, 85

King, Richard, 57

Thomas, 89

Kintbary, 94

Kingsclere, Handred, 38-44, 55-67

" ," Landholders in.

Great Tithes, 93

[119-122

" Great Tithes, 93

" Lordship tithing, 40, 42,

Parsonage, 40, 42, 44, 67

", Swan Inn, 64

", Landholders at, 119, 120 ,

121,122

Kingsnill, Sir William, 21, 34, 39, 42,

,, Henry, Esq., 39, 88

46,86

, Sir John, 21

" $\quad$ Richard, 23, 27, 63, 86

, Sir Richard, 27, 79

" family, 79

Kirby, Thos. F., Esq., 60, 64

Knighte, George, 26, 48, 54, 70, 88,

, James, 66

John, 37, 40, 66

Nicholas, $38,40,41,57,64$

Peter, gent., 42, 44, 67

Richard, 39, 62, 93

Stephen, 40, 43, 64, 66, 67

Walter, 41, 57

Knollys, Sir Francis, 15

Knowle, John, 43, 56

Knowles, H. C., Esq., 45

Lake, Williain, 45, 101

Lambard, William, 20

Lambert, Oliver, 78

, Richard, 72

"Walter, 23, 70, 72, 78

Lan boll, Janies, 50, 69

,, Thomas, 50, 69

Lambilen, John, 30, 78

Lancaster, William, 74

Lardiner, Richard, 86

," Widow, 35

Laske, Hugh, 81

, John, 80, 89 
Laske, Richard, 89

," William, 81

Latimer, Bishop, 12, 13

Launcletts or Laancelewill family.

Laverstocke, 52, 53, 54, 72, 73

Lawnelett, Widow, 73

Landholders at, 126

Lawrence, John, 41

Lawrence Wotton or Wotton St. Law. rence, $33,35,36,37$

', Landholders at, 119 Baldwine, 28, 83

", John, 107

, William, 48, 107

Legatt, John, 32, 56, 91 , Thomas, 66

Lewkener, Sir Richard, 71

Linchenholte or Linkenholt, 45,48 , $100,105,106,111$

Lisle", Alice, 95 "

Landholders at, I23

" Edward, 95

"Sir John, 95

" Thomas, 95

"Sir William, 95

Locke, John, 28

London, Lord Mayor of, 72

Longe, Peter, 31

,"Thomas, sen., 29

William, 65

Longman, Edward, 86

", John, 86

" Robert, 46, 109

", family, 86

Lovelocke, John, 44, 46, 105

" Rowland, 45, 101

, Thomas, 46, 104

Lovinge, Peter, 94 Roter, 94

Losse, Gaye, 36

, Richard, 97

Lacy, Sir Thomas, 79

Ladlow, Mr. George, 31, 53, 73

, family, 73

Lake", William, 54, 73

Laneden ar Lunden, Robert, 45, 106

Lychtielde, 42

Mace, Walter, 41

Magwicke, John, 74

, family, 74

Manfielde, Thomas, 30

Manors, Customs of, 9

Mansill or Mansell, Thomas, 89

Marsh, John, 31, 98 or Mersh Plots, 68

Marshall, Richard, 86

Martine, William, 57

Mascoll, Thomas, 88

Mason, Christian, 23, 53, 73, 78

", Edmond, 43, 56

, George, 41, 56

, James, 55
Mason, John, 39, 57, 61

, Little John, 42

"Robert, 42, 57, 65

, Thomas, 42, 43, 56, 57

Maye or Meye, Thomas, 43, 44, 48,

Mayo, Richard, (Bishop), 38 $61,65,111$

Mathew, Gregory, 52, 53, 72, 73

Maton, Mr., 76

Mayne, William, 74

Meare, Wiliiam, 86

Mercer, John, 47, 107

," William, 48, 107

Merryett, William, 44, 65

Michell, Gay, 73

Milles, William, 23, 47, 79, 109

Millett, John, 43, 56

Misk'ine, John, 97

Money, Richard, gent., 74

Monks' Sherborne, 33, 35, 36, 37, 118

More, Simon, 112

Morgan, William, 88

Morrice, Richard, 90

Mortimer, John, 36

Moyles, Court, 95

Mundey, Robert, 46, 109

Nalder, John, 46, 105

Nashe, Philip, 53, 72

Neale, John, 93

Netley Castle, 46, 110

Newbury, Corporation v. Hobbs, 9

" Domesday, Lord of, 111

, Jack of, 20

", Battles of, 24

, Lyon Inn at, 74

" New England, 81

New College, 95, 100

Newell or Nowell, Christian, 80

$\begin{array}{lll}\text { ", } & \text { " } & \text { Thizabeth, 28 } \\ \text { ", } & \text { Thomas, 25, 86 }\end{array}$

Newman, John, 68

Newtowne, 29, 86

, Landholders at, 118

Norrington or Northington, 52, 53,

, (Wilts) 80

$70,72,126$

Norris, Sir Henry, 23, 78

North, John, 49, 104

North Waltham, 10, 50, 54, 68, 69,

Notte, Thomas, 98

Nutkine, John, 29

Nutsell or Nutley, 53, 70

Natt, Alice, 43,56

Oaklye Charch, 34,36

", "North, 40, 66
", Landholders at, 122
ebarne 16 or Ogbourne, priory, 47, 111


Oliver, John, 97

Osgood, Agnes, 30, 89

Osmond, William, 41, 62

Onlding or Holding, George, 54, 70

Overton, Hundred of, 49-55, 68-74

" ", Landholders, in 125, 126

, Town of, 55, 71, 74

"Iandholders at, 126

Oxenbregg or Oxenbridge, Lady, 23,

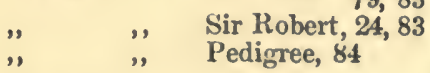

Page, John, 103

Palmer, Johu, 56

Palmes, Francis, gent., 53, 71, 74

, Richard, gent., 52, 72

family, 71

Parker, John, 47, 89, 111

," Robert, 89

, Simon, 30

, Thomas, 45, 99

Widow, 36

Parr, John, 43

"Thomas, 62

Parsons, William, 70

[98-112

Pastroe Hundred, 20, 21, 22, 45-49,

Patye, John, 74

Payne, 67

Pearman, Elizabeth, 30, 90

Peaze or Pesse, John, 30, 89

Peirce or Pierce, A gnes, 29, 97, 101, 102

$$
\text { , " John, 28, 47, 86, } 97
$$

", ", Thomas, 48, 102

Penton, George, 28, 80

, John, 25, 77, 86

, Richard, 77

Thomas, 31, 53, 73, 92

Perrye, Richard, 29

Pescodde, Thomas, 110

Pettye, Thomas, 44, 67

Pevicke, Thomas, 98

Pexsall, Sir Richard, 49

$$
\text { , Ralph, } 77
$$

Phare, William, 103

Philips, Fabian, 2

Philpott, Nicholas, 25, 85 Sir Peter, 71

Pickmonde, Richard, 37

Pike, William, 47, 104

Pile, Richard, gent., 51, 53, 69

Pilgrim, Ralph, 73

Pincke, Edmonde, 35

, Richard, 33, 35

" Robert, 35

Pinmore, Thomas, 89

Piper, John, 103

Plaistowe or l'leastrow, 42, 67

Pococke, Richard, 74

Rolvert, 28

Polhamptine or Polinton,
Polbampton, 51, 53, 54, 55, 70 , Landholders at, 126

Poore,'Jefferie, 23, 25, 81, 86

, John, 46, 105

"Thomas, 25, 48, 85, 106

, family, 81

Portal, Henry, Esq., 52

, Melville, Esq., 52

,Wyndhain, S., Esq., 52

, W. W., Esq., 52

Portchmouth, Edward, 49, 109

Porter, Mr. John, 40 Robert, 88

Portsmouth, Earls of, 18, 24, 78

Potter, 29

Nicholas, 31, 98

Pourchman, John, 109

Powlett, Paulett or Paulet,

$\begin{array}{lll} & & \text { Lord Charles, 108 } \\ \text { ", } & \text { SirHanipden,70,71 } \\ \text { ", } & \text { Sir George, 81 } \\ \text { ", } & \text { ", } & \text { Mr. John, 23, 78 } \\ \text { ", } & \text { ", } & \text { Thomard, 78 } \\ \text { ", } & \text { Sir William, } 46\end{array}$

Poyñder, Hümfrye, 36

Poynter, John, 30

, Richard, 30

"Winifred, 22, 76

Preston Candover, 49, 50, 68

Prior or Pryor, George, 68

, " Henry, 53, 73

", " Henry, jan., 53, 73

, ", Thomas, 55, 61, 73

" , Walter, 63

Priories, Alien, in Hants, 111

Prixmall or Prismall, William, 32, 91,

Prymer or Primer, John, 36

Purchase, Julian, 54 Philip, 38

Parchell, John, 46, 108

Purdue, Robert, 62

Purposture or Purpresture, 93

Pytt ground farm, 66

Queen, William, 29, 77

Quidhampton, 51, 53, 55, 71, 78

$$
\text { , Landholders at, } 125
$$

Rabnett, Thomas, 36

Randall, William, 36

Ratcliffe, Sir Henry, 18

Reade, Mr., 45, 100, 101

, Sir Richard, 107

family, 100

Reading, King's Meads at, 5

Reeve, Simon, 76

Reynolds, John, 32, 44, 91

," Thoms, 29, 77

William, 32,91

IRichardson, Roger, 109 
Rive, Richard, 35

Robinson, Thomas, 30, 90

Roffe, Andrew, 23, 79

Rogers, Thomas, 46, 103

," William, 51, 69

Ronegar or Runniger, William, 70

Rose," John, 49, ï10

family, 70

Rowlande, Peter, 32, 90

Rumboll, Bartholomew, 30, 88

", Charles Edmund, 68

", Christopher, 46, 108

" Drewe, 89, 99

") George, 24, 82

", Henry, 49, 112

" James, 50, 68

", John, 24, 32, 82, 90

," Peter, 112

", Robert, 106

", family, 68

Russell, Lord James, 72

", Thomas, 35, 37

Rutter, Roger, 22, 77

Rydings farm, 65

Salter, Walter, $\mathbf{4 3}, \mathbf{5 7}$

Sandford, 39, 41, 42, 43, 44, 61, 121

Sandleford priory, 57

Sandys, Lord, 18

Saunders, Robert, 47, 112

, William, 57

Saväge, Sir John, 49, 52

Sawyear, John, 27, 94

Saye and Sele, Lords, 51, 82

Searle, William, 54, 69

Selborne priory, 111

Sellhouse or Cell House, 88

Severall or Severalty, 102

Seward, William, 98

Sheffield, Richard, 53, 73

Sherborne-Monks', 33, 35, 36, 37

Sherland, Edmond, 63
Sherwood, J oane, 35 priory, 33, 111

Shetesden or Shoddesden, 21

Shoreland, Richard, 73

Silchester, 71, 92

Silver, Joane, 23, 79

" Mande, 50, 69

", Thomas, 29, 76

Silvester, Alice, 80

"William, 23, 41, 61, 79

Skeye, William, 49, 110

Skinner, Christopher, 25, 86

Slocock, Mr. Samuel, 108

Small, Agnis, 33

" Richard, 35, 54, 70

", William, 54, 69

Smart, Thomas, 47, 104

Smith or Smythe, Alexander, 44, 60

, ", Bartholomew, 28, 81
Smith or Smythe, Davye, 36

$\begin{array}{lll}" & \text { " } & \text { Henry, gent., 39,62,67 } \\ \text { ", } & \text { " } & \text { Rohn, 28, 81 } \\ \text { " } & \text { " } & \text { Simon, 48, 111 } \\ \text { ", } & \text { Thomas, 43, 56 } \\ \text { ", } & \text { Vincent, 47, 107 } \\ & \text { Willian, 40, 66 }\end{array}$

Snowe, Anthony, 35

Soper, John, 36, 37

,, William, 22, 34, 67, 77

Sotwell of Chnte, 63

South, James, 37

, John, 35

, Richard, 32

Southampton, Earl of, 18

Southamton or Southington, 10, 52, 53, 54, 72, 74
Landholders at, 126

"

Spackman, William, 44, 61, 62

Spencer, John, 29, 31, 76, 77, 98

, Thomas, 44, 63

", Walter, 32, 42, 91

, William, 40, 44, 61, 63

Splott, Robert, 85

St. Cross or St. Helen's priory, 111

St. John, Colonel E. J., 108

St. Mary Bourne, 23, 24, 28, 51, 63,

81,82

Landholders at, 114

Stacie,"John, 43, 65

Stanbroke, John, 33

Stanton's farm, 66

Stargrove, East Woodhay, 87

Starke, Thomas, 35

Starke-house farm, 65

Stelle or Steel, William, 88

Steptoe, John, 28, 97

Stevens or Stephens, Amye, 29, 92

$\begin{array}{lll}\text { ", } & \text { ", } & \text { Hugh, 36 } \\ " & \text { John, 92 } \\ \text { " } & \text { Thomas, 92 }\end{array}$

Still or Style, Lawrence, 39, 60

, ", Robert, 73

" " " Simon, 99

'’' Willian, 22, 46, 94, 98

Stoke, 24, 28, 82, 83

"Landholders at, 115

Stonye Hall, 43, 66

Stratheldsaye, priory at, 111

Strike, John, 44, 65

Sutton, Henry, 73

"William, 23, 78

Swampton, 23, 24

Sweetapple, William, 98

Sweetwell, Mr., 48, 102

Swithin, Richard, 91

Sydmonton, 39, 42, 43, 56

" Landholders at, 122 
Tadlej, 52, 53, 55, 73

," Landholders at, 126

Talmage, Robert, 46, 109

Tangley, 47, 48, 49, 106, 107, 108

, Landholders at, 124

Tasburgh, Thomas, 20

Taylor or Taller, Simon, 25, 85

Temple, Willin Thomas, 46, 98, 99,

Thornborongh, John, 21

Thurman, Agnes, 92 John, 29

Toply, Richard, 73

Torroway, John, 97

Torye, Clemente, 35

Trealove, John, 51, 70

Trew, James, 33, 35

, Thomas, 33

Trott, Sir John, 72, 78

Torton, John, 57

Twyne, John, 50, 69

", Thomas, 74

Tyler, John, 39

Underwood, Richard, 23, 81

Upton, George, 36

Vernham Deane, 46, 47, 49, 103, 104

Voaxe, Thonias, 37 Landholders at, 124

Wadlow, Hagh, 53, 54

, Nicholas, 22

" Robert, 22, 45, 101

" Ramboll, 52, 53, 72

William, 77

Wadwick or Warwick, 24

Walbory, ancient British camp, 111

Wall, Francis, 26, 90

Walleys or Wallis, John, 57

$$
\text { " " Richard, } 57
$$

Wallop, Sir Henry, 18, 24,50,72,78

" Sir Oliver, 78

, Sir Richard, 72

, Sir Robert, 24

, Stephen, 72

Williain, 72

Walter, John, 31, 93

Thomas, 89

Warde, Richard, 19

Warham, Lady, 34

," Elioner, 37

, Sir George, 77

, Maude, 36, 37, 54, 69

" Robert, 43, 64

"Thomas, 34

"Willian, Archbishop, 34, 60

Warren, Walter, 110

Waterman, Blandy, 51

$\begin{array}{ll}\text { " } & \text { John, 28, } 80 \\ \text { ", } & \text { Teter, 27, 94 } \\ & \text { Thomas, 110 }\end{array}$

Waterman, Rev. Thomas, 51

Wayte, John, 43, 66

" Richard, 63

Thomas, 41, 43, 66

Webbe, Richard, 38, 41 Thomas, 30,79

Weeke or Wick, 24, 28, 83, 85 Landholders at, 115, 116

Welles, Bartholomew, 89

Wendbolte, Simon, 97

Westcott, Arthur, 92

Weste, Thomas, 61

Weyer, Henry, 43

Weyhill, 13

Wheeler, John, jun., 29, 96

"J John, sen., 29, 96

" Richard, 28, 29, 30, 89, 96

Whetlande, Nicholas, 32,91

Whitchnrch, 1, 10, 22, 29, 30, 74-77

White, Joane, 37 Landholders at, 113

"John, 29, 32, 86, 91, 97

" Richard, 106

" Swithian, 23, 79

" William, 32, 90

", family, 86

Whitear, John, 26, 46, 87, 108

Whitehorne, Widow, 35

Wholdaye, John, 88

" Nicholas, 92

Wibley, Annis or Agnes, 49, 108

Wickens, Francis, 37

Wigge, William, 34, 36

Wigmore, Nicholas, 38, 42, 57, 61

Wilcoxe, Alice, 103

Wilkins, Christian, 80

Willis, John, 65

Wilmot, Ingram, 61

" Walter, 64

Wilson, Rev. Sninner, 68

Winchcombe, Sir Henry, 19

Winchester, 13

1st Marquis of, 46,110
$" \quad$ 2nd Marquis of, 18, 110
Bishops of, 18, 69, 71

, $\quad$ Bishops of, 18, 69, 71

,, College, 64, 100

Winck worthe, Edmonde, 32, 46, 91, 99

\begin{tabular}{ll}
$"$ & John, sen., 26, 90 \\
$"$ & John, jnn., 26, 90 \\
" & Panle, 32, 91 \\
\hline & Kichard, 34, 53, 70
\end{tabular}

Windebank, Sir Thomas, 100

Windsor, royal park of, 5

,

Dean and Canons of, 24, 111

Wissam, John, 36

Witchers, Henry, 90 $[55,90$

Wither or Withers, Edward, 26, 41,

\begin{tabular}{|c|c|c|}
\hline ", & " & $y, 26,41,90$ \\
\hline$"$ & " & Joane, 38 \\
\hline " & " & John, 33 \\
\hline$"$ & " & Margaret, 3 \\
\hline " & ", & \\
\hline
\end{tabular}


Wither or Withers Richard, 31, 33, 35,

$[74,98$

W' Rev, " William, 29, 41, 56 ,

Wood, Rev. Joseph, 1

Woodcott, 2l, 38, 46, 48, 98, 99

Woode, John, 35 Landholders at, 123

Woodhay, East, 10, 26, 30, 31, 74, 78, 87-90

, Landholders at, 115

Woodman, John, 54, 69

Woodward, William, 28, 83

Wooldridge, Simon, 104

," Thomas, 46, 104

Wolverton, 39, 41, 44, 60

," Landholders at, 122

Worting, 33, 35, 37

, Landholders at, 118
Wotton or Wotton St. Lawrence, 33,

$35,36,37,119$

Wrenne, Ingram, 66

" Richard, 63

Wright, Sir Edmund, 72

Wyett, William, 43, 65

Wykeham, William of, 51

Yard land, 10, et seq

Yarmouth, town of, 2

Yeeles, Simon, 27

," William, 27

Younge, Allice, 32, 91

,' Joane, 32, 91

, John, 30, 32, 90, 94

," William, 31, 94 




$$
\begin{gathered}
\text { Money, Walter (ed.) } \\
\text { A perfect booke }
\end{gathered}
$$

PLEASE DO NOT REMOVE CARDS OR SLIPS FROM THIS POCKET

\section{UNIVERSITY OF TORONTO LIBRARY}


